\title{
SOVEREIGNTY, SELF-DETERMINATION, AND THE CATALYST FOR CHANGE IN THE POLITICAL STATUS OF EAST TIMOR
}

\author{
A thesis submitted to Victoria University of Wellington \\ in partial fulfilment of the requirements for \\ the degree of Master of Arts in Politics
}

by Virginia Webb

Victoria University of Wellington

1995 


\section{Abstract}

Starting with the premise that a change in the political status of East Timor is inevitable, and imminent, this dissertation evaluates the potential catalysts for this change. Indonesia invaded East Timor following the initiation of a decolonisation process by the administering power, Portugal. In the twenty - odd years since the invasion, the decolonisation era has come to a close, which has led to reformulation of the principle of self-determination. This principle is crucial to an understanding of the Timor conflict and this dissertation establishes that there is still a firm basis in international law for application of the principle of self - determination to East Timor. Indonesia's role in the conflict is examined, as are internal political changes in Indonesia. It is the political dynamics of the Indonesian state which will, it is argued, open a window of opportunity for the establishment of an independent East Timor. The responses of members of the international community, especially Australia and New Zealand, to the conflict are examined and this dissertation concludes that their realist approach to regional relations precludes them from agitating for change in the political status of East Timor.

Sources include government documents, non-governmental organisation publications, Church publications, personal interviews, public lectures, audio and video recordings and secondary sources. 


\section{Acknowledgments}

Thanks must go my supervisor, Rod Alley, for his encouragement, support, guidance and patience. Thanks also to Dr Gerald Chan for overseeing the final submission of this thesis.

Heartfelt thanks to my Timorese friends for the constant flow of information, you'll always be in my heart. Thanks also to Ines Almeida, Agio Pereira, Sr Kathleen and Jack Otto for their interest and the information they provided. Viva Timor Leste.

Special thanks to Alison Gray for her help in keeping body and soul together.

I'd also like to acknowledge the help and support of staff and research students in the Politics department, especially Virginia McLean who read this entire dissertation and offered fabulous guidance. The Internal Grants Committee must also be acknowledged for funding transcription of radio interviews. 


\section{Table of Contents}

Map of Timor Island $\quad$ page 6

Map of Timor in the Indonesian Archipelago $\quad$ page 7

$\begin{array}{ll}\text { Glossary } & \text { page } 8\end{array}$

$\begin{array}{lr}\text { Introduction } & \text { page } 9\end{array}$

Chapter 1: Self-determination for East Timor page 13

Defining the 'self'

Changing application of the principle

Decolonisation and the aftermath of World War Two

Self-determination at the United Nations

Self-determination in the post-colonial era

Problems with the principle for governments: self-determination and secession

Application of self-determination in East Timor

Indonesia and self-determination

No territorial ambitions

Indonesian support for East Timorese self-determination

Portugal and self-determination in East Timor

The will of the people

Rejecting Indonesia's claim

Chapter 2: Indonesia's Inevitable Annexation of East Timor

page 29

Ideology and politics: the militarisation of government

Redefining 'democracy'

Guided democracy: government by consensus and the transfer of power to the armed forces

The dual function of the armed forces

President Suharto

The impact of military rule on the Timor conflict

Archipelagic Outlook

Indonesia and decolonisation in East Timor

A security matter

Map of the Australian - Indonesian Maritime Boundary

page 42

Chapter 3: Australia, Indonesia and East Timor

The Timor Gap Zone of Co-operation Treaty

The negotiating background

Formal recognition of Indonesian rule

The International Court of Justice

Canberra's pragmatic approach

Australia's support for self-determination 
Criticism of Australia's position

Before the Court

Sovereignty over resources

The Australian High Court challenge

Chapter 4: New Zealand and East Timor

page 62

New Zealand in the wider world

After the cold war

New Zealand in the Asia-Pacific region

Formulating New Zealand's East Timor policy

Other states and New Zealand

Sympathy for Indonesia's situation

Limited information

Accepting integration

New Zealand at the United Nations

Condemnation of FRETILIN

Continuity through changes of government

The 1994 New Zealand parliamentary delegation

Human rights and New Zealand's response: redirecting public attention

Reinventing official policy on East Timor

An ineffective approach

Confusing the issue

Entering the human rights debate

Applying international conventions

State terrorism in Indonesia

Chapter 5: Heading for Change

page 86

The United States

The United States in the United Nations

Practical support for Indonesia: the arms trade

The Clinton administration

\section{Conclusion}

The changing face of government in Indonesia

No capacity to resolve the Timor conflict

The international community: not a catalyst for change 


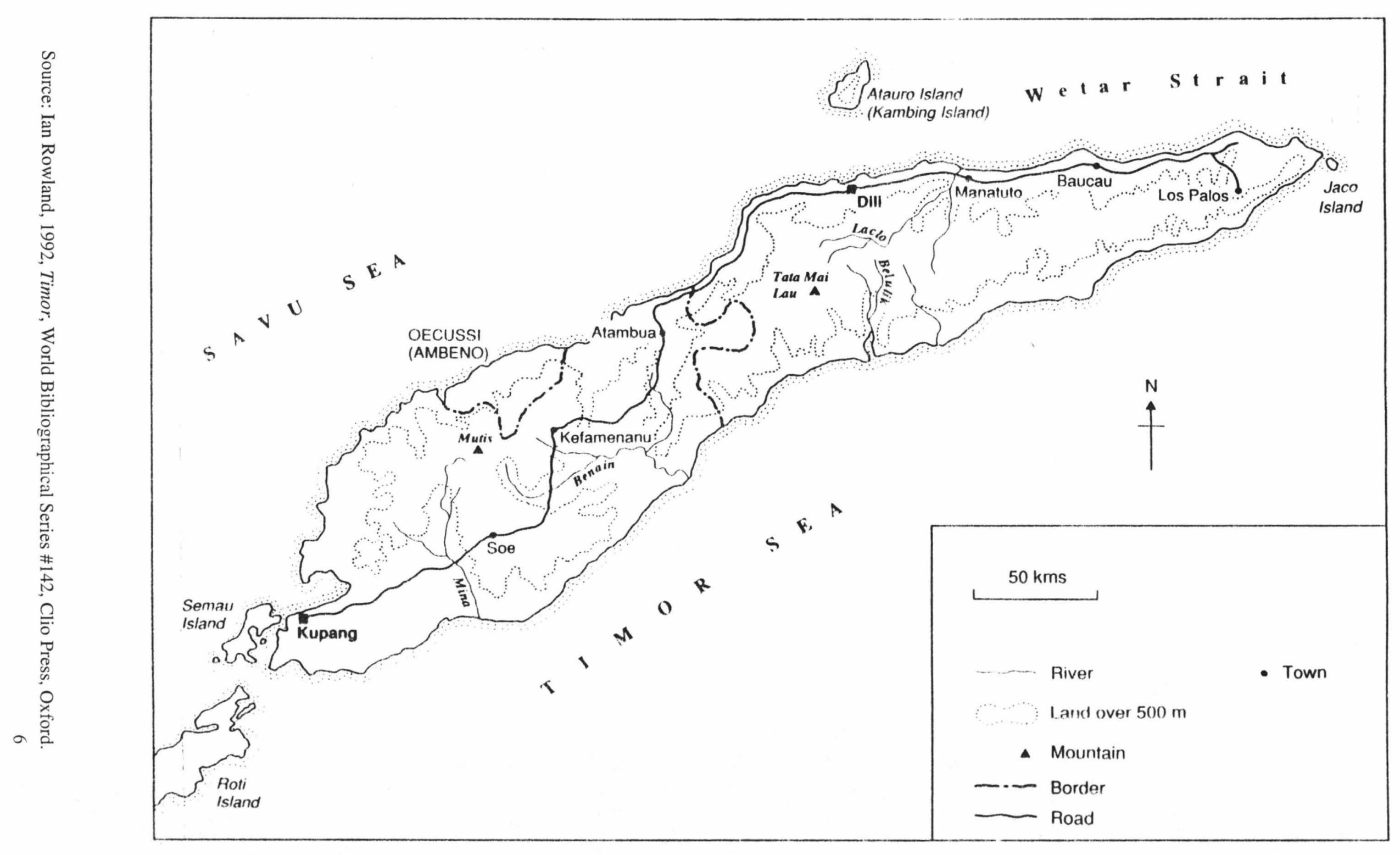




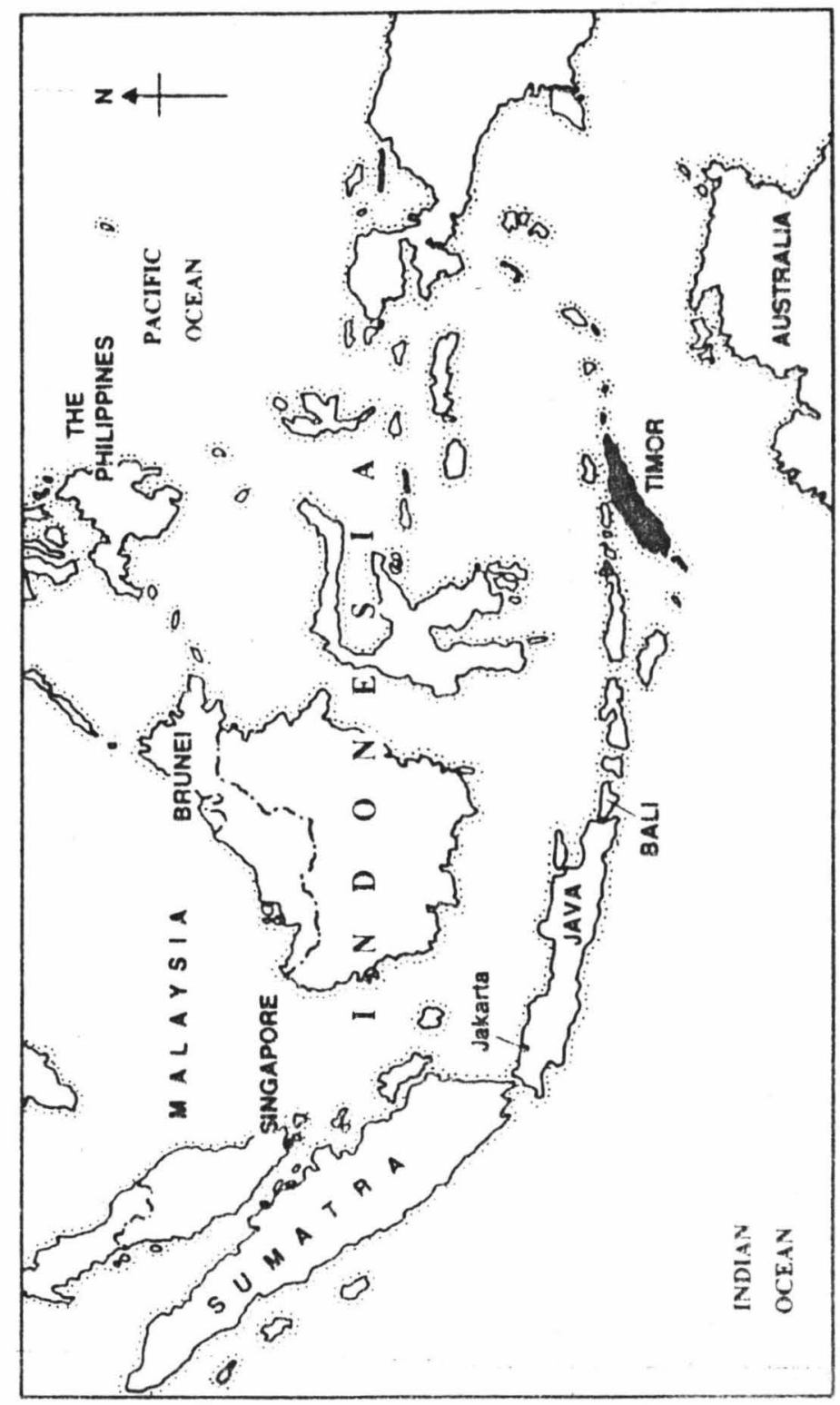

Source: Catholic Institute for International Relations, London. 


\section{Glossary}

ABRI

Indonesian Armed Forces

APODETI

Associacao Popular Democratica, Timorese Popular Democratic Association

ASEAN

Association of South East Asian Nations

EC

European Community

FALINTIL

Forcas Armadas de Libertacao Nacional de Timor-Leste, Armed Forces for East Timor's National Liberation

FRELIMO

Revolutionary Front for the Liberation of Mozambique

FRETILIN

Frente Revolucionara do Timor Leste Independente, Revolutionary Front for an Independent East Timor

ICJ International Court of Justice

IGGI

Inter - Governmental Group on Indonesia

KOSTRAD

Strategic Reserve Command of the Indonesian Military

MP

Member of Parliament

NAM

Non-Aligned Movement

NZ

New Zealand

PGET

Provisional Government of East Timor

PKI

Indonesian Communist Party

UDT

Uniao Democratica Timorense, Timorese Democratic Union

UK

United Kingdom

UN

United Nations

UNCLOS

United Nations Conference on the Law of the Sea

UNGA

United Nations General Assembly

US

United States of America

\section{Note}

The New Zealand Ministry of Foreign Affairs became the Ministry of External Relations and Trade in December, 1988, then changed its name to the Ministry of Foreign Affairs and Trade in June, 1993. Throughout this dissertation, it will be referred to as the Ministry of Foreign Affairs. 


\section{Introduction}

East Timor occupies half of the island of Timor, one of some 13,500 islands in the Indonesian archipelago, which is the world's largest. Portugal established a colonial administration there in 1702, and fought with the Dutch for control of the island for the next 300 years. East Timor was formally divided from West Timor, and the rest of the Dutch East Indies, as recently as $1913^{1}$. Decolonisation was implemented by the Portuguese in 1974 and in the political turmoil which followed, an East Timorese political party, FRETILIN, declared an independent East Timor. The new state was short lived, however. Indonesian troops invaded in December, 1975, and the following July, East Timor was formally incorporated into the Indonesian Republic. The Portuguese administration had evacuated during Indonesia's armed intervention and East Timor entered a period of political limbo - the Indonesian annexation remained unrecognised either by the United Nations or most of its member states; Portugal's responsibility to implement an act of self-determination in East Timor remains undischarged.

East Timor is a small territory, about 19000 square kilometres $^{2}$, with a population of 800000 . This is only a fraction of the 175 million people who make Indonesia the most densely populated country in the world. Currently, nineteen percent of East Timor's population are Indonesians who have migrated there from other parts of the archipelago ${ }^{3}$. Indigenous East Timorese resistance to the Indonesianisation ${ }^{4}$ of their land has been persistent. Armed resistance has been waged by FRETILIN guerillas since the Indonesian invasion and shows no sign of declining. Despite these indications of dissatisfaction with Indonesian rule, and rejection of it by the United Nations, the international community has taken no concerted action to bring about self-determination for the East Timorese.

Although small in size, East Timor was the third largest non-self-governing territory listed by the United Nations Special Committee on Decolonisation ${ }^{5}$. East Timor is larger than, or comparable

1 John Taylor, 1994 “A Brief History of East Timor” New Internationalist, March, p. 10

2 Keith Suter, 1979 West Irian, East Timor and Indonesia, Minority Rights Group Report No. 42, London, p.19.

3 Carmel Budiardjo, 1994b “A Colonised Nation” New Internationalist, March, p.18.

4 'Indonesianisation' is defined by Gietzelt as an acculturation process aimed at incorporating ethnic minorities into the Indonesian nation-state through the education system, the media, economic development and transmigration. The process is predicated on the assumption that inculcation of the Indonesian world view will strengthen national unity - Dale Gietzelt, 1989 "The Indonesianisation of West Papua”, Oceania, Vol. 59, No.3, p.201.

5 Only Namibia and Zimbabwe were larger - Suter 1979, p.19. 
in size and population to several United Nations Member States ${ }^{6}$. This negates the argument put forward by former Australian Prime Minister Gough Whitlam, among others, that it is too small to be politically viable as an independent state ${ }^{7}$. Indonesia has effectively ruled East Timor for almost 20 years but the principle of self-determination is still applicable in its anti-colonial form; the right of the East Timorese to choose the political form of their state has not been extinguished. Self-determination was accepted by all parties (Portugal, Indonesia, the United Nations and the East Timorese political parties) as being the principle at stake in East Timor at the time of Indonesian military intervention, and by other state governments. All have sought to justify their positions using this principle, although disagreeing about the extent to which it has been implemented, and how it has, or should have been expressed.

During the period of Indonesian rule of East Timor, the era of decolonisation has given way to a post-colonial era. The principle of self-determination which informed decolonisation is being reformulated to mean something quite different from the right of a people to choose the sovereign status of the state in which they live. Self-determination has become divorced from the idea of sovereignty, an explosive combination which potentially threatens the territorial integrity of many members of the international community. Application of the principle has been sharply curtailed ${ }^{8}$. Another important change which has occurred during the period of Indonesian rule was he decline of the Cold War. The organising framework of the international community, an East - West dichotomy, has been removed. As a result, nationalist conflicts and internal legitimation crises, such as the East Timor conflict, have become more visible.

Although governments have been willing to voice support for the principle of self-determination in East Timor, in practice they have done little to ensure its implementation. Cold War anxieties, such as the fear of a communist state within the Indonesian archipelago, made the political price to be paid for supporting the principle, and opposing Indonesia, seem too high. As regional security concerns make room for economic interests, a challenge to the status quo (which support for East Timor's self-determination would be) seems a dangerous gamble. This is particularly true for Australia which has reached an accommodation with its large northern neighbour. Nevertheless, self-determination for East Timor is still a political issue, however much this is denied. This dissertation examines how support for the principle of self-determination has been reconciled with

6 For example, Kuwait and members of the Association of Small Island States.

7 Sue Nichterlein, 1982 “Australia: Courtier or Courtesan? The Timor Issue Revisited”, Australian Outlook, Vol. 36, No. 1, p.46.

8 New Zealand's Minister for Treaty Negotiations, Doug Graham, considers self-determination to refer to the preservation of customs, traditions and language; the right of minorities to be consulted on matters of concern to them; and to manage their own affairs. He rejects the idea that self-determination involves a division of the state or of state sovereignty - Interview with Mike Hosking, Morning Report, Radio New Zealand, May 5, 1995. 
the response of the international community to conflict in East Timor, and asks how it might influence that response in the future.

Important to this dissertation is the premiss that change in the political status of East Timor is inevitable, and imminent. The dynamics of the guerilla conflict being waged by the East Timorese resistance make Indonesia's position untenable. Taber identifies the prerequisites of a successful armed resistance as follows:

1. An unstable political situation, marked by sharp social divisions;

2. A political objective, based on firm moral and ideological grounds, that can be understood and accepted by the majority as the overriding 'cause' of the insurgency, desirable in itself and worthy of any sacrifice;

3. An oppressive government with which no political compromise is possible;

4. Some form of revolutionary political organisation, capable of providing dedicated and consistent leadership towards the accepted goal;

5. The clear possibility, or even probability, of success. ${ }^{9}$

As this dissertation will show, these are all clearly identifiable characteristics of the conflict in East Timor, which suggests that Indonesia does not have the capacity to successfully integrate East Timor into the Republic of Indonesia.

Chapter One reviews the development of the principle of self-determination in international law and practice. The problems which the principle poses for governments in the post-colonial era are discussed and the case for self-determination in East Timor is established. This dissertation argues that there is a firm legal basis for the rejection of Indonesian rule in East Timor. Because Portugal has never satisfactorily discharged its responsibility for East Timor, it is still considered a nonself-governing territory. As such, the Timorese must be allowed to freely determine the sovereign status of their state in accordance with the practice of decolonisation. Neither the unilateral declaration of independence by FRETILIN nor the 'referendum' held by the Indonesian-backed Provisional Government of East Timor can be considered legitimate acts of self-determination.

Chapter Two examines why, given its outspoken support for self-determination and its own revolutionary anti-colonial origins, Indonesia annexed East Timor, having gained control of the territory by way of an act of aggression. Indonesia's perspective on the conflict differs somewhat from that of the United Nations. It is, however, still a member of the UN and has dealt with the

9 Taber, Robert, 1969, The War of the Flea: Guerilla Warfare in Theory and Practice, Paladin, St. Albans, p. 31 . 
Timor issue in that forum. Indonesia justifies its rule in East Timor using the framework for selfdetermination advocated by the UN. When considering Indonesian involvement in the Timor conflict, it is clear the sovereignty and self-determination play a crucial role in the discourse and actions of the Indonesian state. This chapter also looks at the incapacity of the Indonesia state to deal with political dissent and armed resistance, such as that waged by the East Timorese, and the internal political dynamics of the Indonesian state.

Chapter Three considers a case before the International Court of Justice in which Portugal alleged that Australia ignored its rights as administering power of East Timor when it concluded the Timor Gap Zone of Cooperation Treaty with Indonesia. Indonesia was not a defendant in this case, and refused to recognise the jurisdiction of the Court. Because of this, the Court declined to give a ruling but the case raised important legal questions. Particularly, whether Australia was in breach of an obligation not to recognise Indonesian rule in East Timor, pending an international determination of East Timor's disputed sovereignty. Australia's response to the Timor conflict generally is also discussed. Relations between Australia and Indonesia are complex and interaction over East Timor reveals these complexities, and the realist approach taken by Australia to regional affairs. The Australian response has been the most extreme of the states considered in this dissertation.

Chapter Four examines New Zealand's response to the Timor conflict. New Zealand does not have the geographical proximity to Indonesia that Australia has and consequently has a less complex bilateral relationship. New Zealand's response has been shaped by factors such as economic and security interests, regional perspectives and involvement in the Western Alliance. New Zealand's response is, in many ways, typical in that it is informed by power politics. Documents made available by the Ministry of Foreign Affairs indicate that New Zealand's primary concern has not been with the legal and moral aspects of the Timor conflict, but with the implications it has for regional stability and bilateral relations. When commenting about the impact of Indonesian rule in East Timor, third parties such as New Zealand and Australia do not discuss these aspects and instead express concern about human rights violations by Indonesia's armed forces.

The common pattern in the response of Indonesia, Australia, and New Zealand is support for the principle of self-determination in the abstract, but tacit acceptance of Indonesian rule in practice. The final chapter traces this same pattern in the response of the United States and other governments. This chapter also looks at changes in Indonesia's political landscape, and at changes which are imminent, such as the end of Suharto's presidency. The chapter concludes by suggesting that internal political crises in Indonesia will provide a catalyst for a change in the political status of East Timor, arguing that Indonesia will find it increasingly difficult to sustain its position there in the face of widespread resistance and persistent armed conflict. 


\section{Chapter 1 \\ Self-determination for East Timor}

Crucial to an understanding of the conflict in East Timor is the principle of self-determination. A comparatively recent development in international politics, self-determination has become a major force in modern political history. The principle is problematic however, particularly in its application to East Timor. East Timor is considered a non-self governing territory by the United Nations and is therefore entitled to independence in accordance with international law and the practice of decolonisation, but the reality of Indonesian rule in East Timor cannot be ignored. Because Indonesia views East Timor as an integral part of the state, it does not accept the need for a formal act of decolonisation to take place. Thus any debate on the future of East Timor in which Indonesia takes part is outside of the discourse on decolonisation. Removed from the context of decolonisation, the principle of self-determination becomes ill-defined and of uncertain application.

To a large extent, the confusion surrounding the definition and application of self-determination is a result of confusion surrounding the definition and extent of its correlative, sovereignty; particularly as to whether sovereignty is of enduring application, so far as determination of international states by self-defining groups is concerned. The word 'sovereignty' has different meanings in different contexts and its use, therefore, is often confusing1. In the case of East Timor and the call for self-determination, sovereignty can be understood as meaning independence from all other states and recognition as a sovereign state in international law. Hinsley notes that the existence of sovereign authority in the separate community is the essential qualification for membership of the international community and that the principle that there is no authority over and above the state is widely accepted 2 . In East Timor, self-determination has come to mean the establishment of a sovereign state ${ }^{3}$. Taylor argues reluctance to accept self-determination in another form, such as autonomy within the Republic of Indonesia, has become a psychological barrier to reaching a settlement 4 .

1 Falk and Camilleri note that current definitions of sovereignty are rigid and defining compared to past political arrangements which were characterised by subtle and fluid relations between rulers and ruled. The hegemony of Rome of Egypt bears little resemblance to the 'separate but equal' implication of modern sovereignty - Jim Falk \& Joseph A. Camilleri, 1992 The End of Sovereignty?: The Politics of a Shrinking and Fragmenting World, Edward Elgar, ALdershot, England, p. 12.

2 F.H. Hinsley, 1986 Sovereignty (2nd ed), Cambridge University Press, Cambridge, p.215.

3 Peter J. Taylor, 1989 Political Geography: World Economy, Nation State and Locality, Longman, New York, p. 190.

4 ibid. 
The concept of self-determination originates with two strands of philosophical thought: that all people have equal political rights, and that state power is legitimised by popular sovereignty 5 . Early expressions of the principle can be found in the Declaration on the Rights of Man and the American Declaration of Independence which affirm that governments derive their authority from the people they govern. This link between self-determination and popular sovereignty was preserved in the decolonisation era, and formalised in United Nations resolutions. However in the post decolonisation era the meaning of self-determination has been reformulated and links between the principle of self-determination and state sovereignty tested.

\section{Defining the "self"}

Under international law, territories whose inhabitants have not yet attained self-government are most often identified as the units able to claim the right to self-determination6. Accordingly, selfdetermination can be defined as the right of people living in a territory to determine the political and legal status of that territory - for example by establishing a state of their own or by choosing to become a part of another state 7 . This approach to defining who is entitled to claim the right of self-determination is supported by United Nations General Assembly Resolution 1541 (XV) 8 which presumes that a non-self-governing territory subject to the provisions of Article 73 of the United Nations Charter is any territory "which is geographically separate and is distinct ethnically and/or culturally from the country administering it"9. Resolution 1541 (XV) is applicable in the

5 C.E. Merriam Jr., 1968 History of the Theory of Sovereignty Since Rousseau, AMS Press, New York, p. 122 .

6 Ofuatey-Kodjoe, 1977 The Principle of Self-determination in International Law, Nellen Publishing Co. Inc, New York, p.44

7 Michael Akehurst, 1987 A Modern Introduction to International Law, Allen and Unwin, London, p. 290 .

8 The Declaration on the Granting of Independence to Colonial Countries and Peoples.

9 Objective characteristics such as language, religion, history, location and ethnicity provide some evidence of distinctiveness but a subjective perception of this is also important. In East Timor the perception of distinctiveness has become increasingly acute in the years since the annexation of East Timor by Indonesia. Expression of this can be found in the spread of the Tétun language, its use in daily life as well as in songs, drama, and literature; and in increasing membership of the Catholic Church. Hull estimates $13 \%$ of a population of 450000 were Catholic in 1952 . This had increased substantially to $30 \%$ of a population of 659000 in 1974 , and by 1994 to $80 \%$ of the current population. The Church identifies itself as the only institution within East Timor able to voice the aspirations of the Timorese people to obtain a peaceful resolution to the conflict. It offers a cultural and physical space beyond the normal reach of the Indonesian authorities. The Catholic Church has strongly identified with the East Timorese and has frequently spoken out on their behalf. Increased membership of the Church therefore has a political aspect and many public protests against Indonesian rule have been associated with religious events - Ramos-Horta, 1987, p.205; Dr Geoffrey Hull, 1992 East Timor: Just a Political Question?, Occasional Paper \#11, Australian Catholic Social Justice Council, Sydney; New Internationalist, March 1994, p.18; Jack de Groot, 1993, introduction to The Church and East Timor, The Catholic Commission for Justice, Development and Peace, Melbourne. 
case of East Timor which is a clearly defined territory and is both geographically separate and ethnically and culturally distinct from its administering power, Portugal. It is also geographically separate from Indonesia, in spite of a shared border, and is certainly ethnically and culturally different.

Explicit in Article 73 of the UN Charter is the important consideration of accountability of colonising powers to the international community, as represented in the United Nations, for the discharge of their responsibilities to implement acts of decolonisation. Once an act of decolonisation has occurred to the satisfaction of the UN, the issue is effectively resolved and cannot be revisited

Resolution 1514 (XV), and the Declaration on Principles of International Law10 (Resolution 2625(XXV)) were adopted At the 15th General Assembly of the United Nations in December, 1960 , the latter by a unanimous vote. These were landmark resolutions in that they supported selfdetermination for all peoples but being firmly linked to decolonisation, they also stress preservation of territorial integrity (all UN member states being vulnerable to claims from ethnic or indigenous minorities).

The provisions of these two Resolutions which establish both the illegality of Indonesian occupation and the continuing responsibility of Portugal, are:

By virtue of the principle of equal rights and self-determination of peoples enshrined in the Charter of the United Nations, all peoples have the right freely to determine, without external interference, their political status and to pursue their economic, social and cultural development, and every state has the duty to respect this right in accordance with the provisions of the Charter. UNGA Res 2625 (XXV); unanimous. 11

The subjection of peoples to alien subjugation, domination and exploitation constitutes a denial of fundamental human rights, is contrary to the Charter of the United nations and is an impediment to the promotion of world peace and cooperation. UNGA Res 1514 (XV); 89:0:9.

All peoples have the right to self-determination; by virtue of that right they freely determine their political status and freely pursue their economic, social and cultural development. UNGA Res 1514 (XV); 89:0:9

Inadequacy of political, economic, social or educational preparedness should never serve as a pretext for delaying independence. UNGA Res 1514 (XV); 89:0:9.

10 The full title of this Resolution is "The Declaration on Principles of International Law Concerning Friendly Relations and Co-operation Among States in Accordance with the Charter of the United Nations'.

11 This resolution was first adopted in 1960 as UNGA Res. 1541 (XV) and was later inserted into the Declaration on Principles of International Law, UNGA Res. 2625 (XXV). 
All armed action or repressive measures of all kinds directed against dependent peoples shall cease in order to enable them to exercise peacefully and freely their right to complete independence, and the integrity of their national territory shall be respected. UNGA Res $1514(\mathrm{XV})$; 89:0:9.

The final paragraph of Resolution 1514 (XV) relates the right of self-determination to human rights and to the question of sovereignty. It states:

All States shall observe faithfully and strictly the provisions of the Charter of the United Nations, the Universal Declaration of Human Rights and the present Declaration on the basis of equality, non-interference in the internal affairs of all States and respect for the sovereign rights of all peoples and their territorial integrity.

These paragraphs identify self-determination with independence, but in fact the United Nations accepts other forms of self-determination as legitimate provided they are legitimate and not enforced outcomes of spurious acts of self-determination. Resolution 1541 (XV) provides for a choice between independence, integration with another independent state, and free association with an independent state.

\section{Changing application of the principle}

The development of the principle of self-determination in international law has been a gradual process and is marked by changes in its interpretation and application which correspond to changes in the international community 12. Although the idea of self-determination can be traced to the American Revolution, it emerged as a political principle at the 1919 Paris Peace Conference following World War 1 where it was promoted by American President Woodrow Wilson. Wilson identified national identities based on territory, language, culture and shared history as the criteria for claims to self-determination 13 but was imprecise and inconsistent in his use of the term 'selfdetermination'14. The 'self' to which the principle applied was unclear and delegations to the conference critical of the concept interpreted it in its most extreme form to mean self-determination for all ethnic groups however small. Another US delegate to the Paris conference, Secretary of State Robert Lansing, considered the phrase 'self-determination' to be "loaded with dynamite. It will raise hopes which can never be realised" 15 .

12 Discussion on the principle of self-determination in the United Nations General Assembly was provoked by the Lichtenstein Proposal on Self-Determination. A summary of the discussion, prepared by the Chair, is contained in the Appendix.

13 Dov Ronen, 1979 The Quest for Self-determination, Yale University Press, New Haven, p.10.

14 Halperin et al, 1992 , p.16.

15 cited in Halperin et al, 1992, p.17. 
The principle of self-determination was indeed explosive, having the potential to legitimise any struggle against oppression and therefore posed a challenge to existing states. Following the Second World War, application of the principle was sharply curtailed and came to refer to the right of colonies to independence or voluntary integration with another state. Heraclides points out that in practice this means independence from Western colonial rule and was not applied to nonWestern empires 16 . The principle was also not applicable in cases such as Indonesia which, prior to Dutch colonial rule had itself been an empire encompassing vast territory and several peoples. The Dutch East Indies was entitled to self-determination but not the composite parts of the archipelagic colony 17 . On the whole, the colonial state was determined to be the entity entitled to self-determination, not pre-colonial nations, regardless of how coherent they may have been before coming under Western dominance. Such parameters are not necessarily accepted by groups claiming the right to self-determination, however. In addition to a horizontal sense of unity among the group, Falk and Camilleri point out that groups also have a vertical sense of community through time - a shared history 18 . Thus, Indonesia's first president, Sukarno, could speak of hundreds of years of oppression endured under Dutch colonial rule although Indonesia itself had been created only recently.

The League of Nations had effectively restricted the application of the principle of selfdetermination to European states. A system of Mandates and Trust Territories was endorsed to deal with the colonial possessions of the defeated European powers; the time frame for their selfdetermination was unspecified. As the European powers began to decolonise, the United Nations transformed the principle of self-determination into an anti-colonial weapon.

\section{Decolonisation and the aftermath of World War Two}

Under the auspices of the United Nations, which obliges its members to respect the "sovereign equality" of all states 19 , the principle of self determination legitimised anti-colonial struggle and saw many former colonies become full-fledged members of the international organisation. In the decolonisation process the concept of popular sovereignty remained intact, although self-

16 Alexis Heraclides, 1991 The Self-determination of Minorities in International Politics, Frank Cass, London, p.22.

17 Post-colonial Indonesia initially comprised sixteen component states which were guaranteed internal and, should they seek it, external self-determination. Regional unrest led to the consolidation of the state into a unitary republic - Gavan Breen, 1993 Let Them Be: West Papua Revisited, Australia West Papua Association, Melbourne, p.3.

18 Falk \& Camilleri, 1992, p.55.

19 Werner Levi, 1976 Law and Politics in the International Society, Sage Publications, Beverly Hills, p.42. 
determination was applied to territories (following colonially established borders) rather than nationalities (ethnic or linguistic groupings).

Application of the self-determination principle in the era of decolonisation was relatively simple. The colonial powers themselves had, in defining their colonial empires, determined the basis on which self-determination would be applied. Independence was granted or ceded on the basis of the geographical boundaries of former colonies, disregarding any divisions these drew across ethnic, linguistic or religious lines - the 'natural' political entities existing within or across colonies. Chapters XI and XII of the United Nations Charter refer to decolonisation and both emphasise territory rather than ethnicity as the basis for decolonisation - a deliberate effort to curtail the applicability of the principle. Neither refers explicitly to self-determination but establish the principle indirectly by requiring administering powers to bring their territories to the point of independence. The 'self' was limited by treating each colony as a whole political entity not to be divided any further, so far as that was possible.

\section{Self-determination at the United Nations}

Self-determination is specifically mentioned in only two articles of the United Nations Charter: Article 1 where it invokes "the principle of equal rights and self-determination of peoples", and in Article 55 which calls for respect for the principle of equal rights and self-determination for all peoples.

Although the United Nations Charter does not mention the 'right' of self-determination, subsequent resolutions adopted by the Security Council and the General Assembly, as well as Covenants awaiting ratification by member states, have effectively revised the provisions of the Charter by authoritatively interpreting it to allow for the recognition of the right of self-determination 20 . Whether the right of self-determination has the force of law can be challenged. The United Nations General Assembly (UNGA) has no law making capacity so Declarations and Resolutions of the UNGA are not legal instruments per se, but they do establish international principles and norms which are considered binding 21 .

Advisory opinions from the International Court of Justice have further contributed legal weight to the principle of self -determination. In 1971 the Court delivered an advisory opinion concerning Namibia in which it recognised the principle of self-determination as international law and enshrined in the UN Charter. The Court also recognised its subsequent development in the

20 Wilson, 1988 International Law and the Use of Force by International Liberation Movements, Clarendon Press, Oxford, p.68; Akehurst 1987, p.294.

21 W. Ofuatey-Kodjoe, 1977 , p.39. 
Declaration on the Granting of Independence to Colonial Countries and Peoples, Resolution 1514 $(\mathrm{XV})^{22}$. In a 1975 advisory opinion on Western Sahara, a Judge Petren of the Court wrote that:

[A] veritable law of decolonisation is in the course of taking shape. It derives essentially from the principle of self-determination of peoples proclaimed in the Charter of the United Nations and confirmed by a large number of resolutions in the General Assembly. 23

\begin{abstract}
Although advisory opinions are not binding interpretations, they are authoritative explications of the content of international law. Further evidence of the development of the right of selfdetermination can be found in the International Covenants on Human Rights. Common Article 1 of these Covenants states that:

All peoples have the right of self-determination. By virtue of that right they freely determine their political status and freely pursue their economic, social and cultural development. 24
\end{abstract}

Although the Covenants have not been widely ratified by member states, they nevertheless indicate the evolution of the principle of self-determination into a right under international law. The Covenants, once ratified, carry the legal weight of multilateral treaties.

It is evident that under international law, the East Timorese are entitled to exercise their right of self-determination, and this is widely recognised, even by Indonesia. The East Timorese are not fighting to establish their right to self-determination, but to have this right respected.

\title{
Self-determination in the post-colonial era
}

In the post-colonial era, application of the principle is less widely agreed upon. Calls for selfdetermination today potentially challenge the territorial integrity of established sovereign states. Because modern states are essentially artificial constructions, dependent for their legitimacy on recognition by other states and by the citizens who live within them, any challenge to that legitimacy, particularly from indigenous groups, provokes a hostile or defensive reaction. Calls for self-determination are a rejection of the authority of the state and/or its geographical extent.

22 Wilson, 1988, p.76.

23 ibid., p.77.

24 The International Covenant on Economic, Social and Cultural Rights and the International Covenant on Civil and Political Rights were adopted by UNGA Resolution 2200A (XXI), 16 December, 1976. To date they have not been widely ratified. 
The implications of this are far-reaching. Whilst Hinsley argues that sovereignty is not a act but an idea, a claim about the way power should be exercised 25 , Falk and Camilleri disagree. They point out that sovereignty is more than just an idea; it is part of the general discourse of power. Sovereignty justifies international political arrangements by explaining them as if they were a part of the natural order of things 26 . The sovereignty debate is anchored firmly in the realist school of international relations. From a realist perspective, the international community operates as a collection of individual sovereign states, organised into regional groupings such as the Organisation of African Unity or the Association of Southeast Asian Nations, and into the United Nations where almost all states are represented. States are fictionalised as persons and become individuals for the purpose of analysis. Sovereignty is crucial to the functioning of international organisations and all inter-state relations because it bestows individual characteristics upon territorial entities.

Sovereignty informs international legal principles such as the principle of non-intervention and legitimises legal instruments such as treaties and international covenants. Yet some aspects of international law also challenge the idea of sovereignty by qualifying it; the International Covenants on Human Rights for example, proscribe states from infringing on the individual rights of its citizens. The concept of sovereignty is not only qualified by law however. Janis 27 challenges the utility of the concept of rigidly defined national sovereignty in light of structural changes in inter-state relations which mean transactions - economic, environmental, cultural, political, social or military - increasingly transcend national boundaries.

Application of the principle of self-determination in the post-colonial era need not necessarily mean a challenge to the existence of sovereign states. Some suggest that exercise of selfdetermination can lead to a number of outcomes ranging from protection of the rights of minorities to cultural or political autonomy to independent statehood 28 . Because not all objectives of self-determination require independence and the fragmentation of an existing state, outright rejection of self-determination claims by governments is inappropriate. Sovereignty is either being divorced from the principle of self-determination or being defined more narrowly.

Whilst much of the justification for self-determination which was relevant during the anti-colonial struggle is still applicable to East Timor, it still being technically a non-self-governing territory,

25 Hinsley, 1986, p.1.

26 Jim Falk \& Joseph Camilleri, 1992 The End of Sovereignty?: The Politics of a Shrinking and Fragmenting World, Edward Elgar, Aldershot, England. p.11.

27 Mark W. Janis, 1991 "International Law?" Harvard International Law Journal, 32:2, p.368.

28 Halperin et al, 1992 Self-determination in the New World Order, Carnegie Endowment for International Peace, Washington D.C.,p.47. 
continuing debate on the issue represents a transformation of the principle into a post-colonial issue; settlement or resolution of the East Timor conflict will occur in a modern political context.

\section{Problems with the principle for governments: self-determination and secession}

Crawford writes that since 1945 there has been "perhaps no more divisive issue among writers (at least in the Western tradition of international law) than the question of whether there exists a legal right or principle of self-determination of peoples." 29 There is an inherent tension between the principle of self-determination and the strong support for territorial integrity within the UN, expressed in Resolutions condemning aggression and in the territorial basis of UN references to self-determination. The international community has often refused to support attempts to create independent states which would have fragmented existing states 30 , for example Biafra, Kurdistan and Katanga. There have been some exceptions to this however, notably Bangladesh and Eritrea. Even these apparent exceptions must be qualified however. Both states emerged after a period of war, and only when the dominant actor effectively ceded the territory, avoiding an inevitable protraction of the conflict. UN Secretary General, U Thant, said in 1970:

The United Nations' attitude is unequivocal. As an international organisation, the United Nations has never accepted and does not accept and I do not believe it will ever accept the principle of secession of a part of its Member State ${ }^{31}$.

Classification of a claim as a legitimate (in UN practice this means anti-colonial) expression of self-determination however imposes an obligation on the international community to bring independence to the claimants. This perhaps accounts for the reluctance of governments and lawyers to accept the principle of self-determination as existing in international law and their preference for classifications such as 'insurgency' or 'insurrection' to label armed uprisings against the state. Certainly the Indonesian government favours the term 'bandit' over 'guerilla', which has political implications, when referring to FRETILIN fighters.

Heraclides argues that in fact the principle of self-determination offers legal protection to states against secession 32 . He argues that the principle of self-determination as articulated in United Nations instruments is an exclusively anti-colonial tool and that once a colony has become

29 James Crawford, 1979 The Creation of States in International Law, Clarendon Press, Oxford, p.85.

30 Halperin et al, 1992, p.14.

31 Press Conference at Dakar, Senegal, January 4, 1970, cited in Halperin et al, p.15.

32 Heraclides, 1991, p.21. 
independent, claims for self-determination from groups within the state are invalid. In an independent state, self-determination refers narrowly to the right of a people to freely select their form of governments and constitutional status government. Essentially, once a state qualifies for membership of the United Nations, the principle of self-determination no longer applies and the state is protected from any challenge to its territorial integrity, either from within or from an external source, by international law.

International law applies to states, not to groups within them. Thus international law mitigates any challenge to the state to which it applies. Having emerged from the states which make up the international community and dependent upon them for its weight (cannot be applied without consent of the state in question), international law must proscribe any activity which threatens the state and thus its own legitimacy.

\section{Application of self-determination in East Timor}

Under the influence of United States President, Woodrow Wilson, the League of Nations had favoured a plebiscite method of determining statehood. Plebiscites enshrine the notion of popular sovereignty and enable the expression of the right of people to choose the form of government under which they live. In the United Nations' Charter and Resolutions pertaining to selfdetermination, sovereignty is interpreted as being democratic in nature; power resides with the people. In a decolonisation situation the people of the territory in question, by virtue of the right of all peoples to self-determination, must freely determine the future political status of the territory. Any alteration to the political form of a colony or state without some degree of popular consent is viewed with suspicion. East Timor, annexed in the wake of an invasion by a powerful neighbour is just such a case. The East Timorese have been able to lobby effectively on the sovereignty issue because the manner in which East Timor was incorporated into Indonesia cannot be accepted as having been freely determined.

Furthermore, Halperin et al identify internal self-determination, the right to participate in government, as a corollary of external self-determination (the right to choose the sovereign status of the state) ${ }^{33}$. The Indonesian political system offers few avenues of political expression for the East Timorese, particularly those who seek to disengage from the state. Armed resistance is not considered a legitimate form political expression in Indonesian law although it must be understood as that.

33 Halperin et al., 1992, p.17. Buchheit further cefines external self-determination as the right of a people to pursue political, economic and cultural development without interference or coercion from any other state; and internal self-determination as the right of all segments of a population to influence the constitutional and political structure of the system under which they live - Buchheit, 1978, p.14. 


\section{Indonesia and self-determination}

As a member of the non-aligned movement (NAM), Indonesia has committed itself to uphold the rule of law and the principles of the United Nations Charter; to ensure respect for the sovereignty of nations and strict adherence to the principle of non-interference in the internal affairs of other states $^{34}$. It is also "committed to the peaceful resolution of disputes in all regions of the world through a sustained process of dialogue and negotiation" 35 .

Jakarta sees no contradiction between these commitments and its ongoing war with the East Timorese guerillas, although the heads of government of the non-aligned movement have twice affirmed the right of the East Timorese to self-determination in spite of Indonesia's claim that they have already exercised this right. The non-aligned movement endorsed United Nations Security Council resolutions 384 (1975) and 389 (1976) calling for the immediate withdrawal of Indonesian troops from East Timor at its 1976 meeting in Colombo. At the 1985 meeting in Luanda, Angola invited a FRETILIN delegation, provoking heated debate on the Timor issue 36. Although the delegates were divided on the issue, vindication for Indonesia was far from forthcoming. Indonesia takes the position that a legitimate act of self-determination did occur in which the East Timorese asked to be integrated into The Republic of Indonesia, and to which Indonesia responded. This "act of self-determination" is discussed below.

\section{No territorial ambitions}

A senior Indonesian diplomat, Samsi Abdullah, was quoted in the New York Times in January, 1976, as saying:

Indonesia has no territorial claims on Portuguese Timor (despite the fact that it is the heart of Indonesian territory)...Indonesia will not take over Portuguese Timor but will accept integration, should the people of the area, democratically and without terrorists' guns pointed at their heads, choose this course 37 .

"Terrorists" presumably refers to FRETILIN, not to the Indonesian 'volunteers' who had arrived in Dili in December 1975.

34 In "The Jakarta Message" from The Tenth Non-Aligned Movement Summit, Jakarta, September 1992.

35 ibid.

36 Jose Ramos-Horta, 1987 Funu:The Unfinished Saga of East Timor, The Red Sea Press Inc., Trenton, New Jersey, p.162.

3711 January, 1976, cited in Kees Lagerberg, 1979, West Irian and Jakarta Imperialism, C. Hurst \& Co., London, p.27. 
Denial of territorial ambitions was a common theme in Indonesian political rhetoric leading up to the invasion. In October 1974, President Suharto's declared Indonesia's basic stance on East Timor was that Indonesia had no territorial ambitions; that it respects the right of the people of East Timor; and that should the people of East Timor wish to join Indonesia they could not do so as a state but only as part of the unitary state of The Republic of Indonesia 38 .

\section{Indonesian support for East Timorese self-determination}

In a 1977 publication, Decolonisation in East Timor, the Indonesian Department of Foreign Affairs wrote that, based on its own historic commitment to anti-colonialism and humanitarian principles, the Indonesian government had a moral obligation to assist the people of East Timor and to ensure that the decolonisation process could be implemented in accordance with the ideals and wishes of the entire population of the territory 39 . Jakarta argued that it firmly supported the free and democratic exercise of the right to self-determination by the East Timorese in accordance with the provisions of the UN Charter and Resolutions 1514(XV) and 1541(XV) of the General Assembly 40 . These assertions indicate that Indonesia places the East Timor issue firmly in the context of international law. Jakarta attempts to justify its incorporation of the territory in these terms.

Indonesia maintains that East Timor was integrated into the Republic of Indonesia in accordance with the wishes of the people of East Timor, and that this is a legitimate form of selfdetermination as defined by Resolution 1541 (XV). Indonesia claims the wishes of the people were expressed by a Peoples Assembly who formally requested integration in June 1976. Indonesia then passed legislation through the House of Representatives of the Republic of Indonesia on July 17, 1976, making East Timor an Indonesian province. So far as Indonesia was concerned, this legitimised its control of the territory.

Indonesia either protests criticism of its actions in annexing East Timor, or simply refuses to acknowledge any such criticism. The former Vice-President of Indonesia, Adam Malik, illustrating complete denial of criticism, wrote in his 1980 biography:

I am gratified that the process of the integration of East Timor into the territory of Indonesia has been finalised satisfactorily for all sides concerned. It is true that initially the neighbouring countries, including Australia, seemed to be doubtful of the good intentions of Indonesia. But when

38 Kristiadi, 1986 "The Decolonisation of East Timor: A Historical Review" The Indonesian Quarterly, Vol.14, No.4, p.551-552.

39 Department of Foreign Affairs, 1977, Decolonisation in East Timor, Republic of Indonesia, p.38.

40 Department of Foreign Affairs, 1984, East Timor After Integration, Republic of Indonesia, p. 52 
subsequently it was established as a fact that Indonesia had but accommodated the will of the people of East Timor to be united with their brothers, then the countries in question accepted and consented to the course of action taken by Indonesia. 41

When East Timor appeared on the agenda of the 31st session of the United Nations General Assembly in 1976, Indonesia objected to its inclusion on the grounds that the decolonisation process had culminated in the integration of East Timor with Indonesia and further discussion of the issue represented interference in the internal affairs of Indonesia. The issue remained on the agenda however, and in 1982 the 37th session of the UNGA had before it a working paper prepared by the UN Secretariat and a draft resolution on East Timor. The working paper criticised the noninvolvement of the UN in the act of self-determination which resulted in Indonesia's annexation of East Timor. Indonesia protested at this, saying "the Provisional Government of East Timor [PGET] had made every effort to have the United Nations participate in the decolonisation process" 42 and pointed out that United Nations participation in the process of decolonisation is not mandatory.

The PGET referendum was promoted by Indonesia as legitimate. Advice from New Zealand 43 , among others encouraged Indonesia to attempt to gain UN recognition of the referendum to ensure it was acceptable to more than just the seven states who sent representatives to witness the act 44 . Jenkins summarises Indonesia's version of events thus:

[The East Timorese] had thrown off the colonialist yoke and decided on integration with their brothers across the border in Indonesia. Jakarta, having made strenuous efforts to ascertain that they truly sought such a union, had eventually acceded to their request. 45

\section{Portugal and self-determination in East Timor}

Prior to the April Revolution which overthrew the Caetano regime, Portugal had rejected successive UNGA resolutions recognising the right of self-determination for East Timor on the grounds that East Timor was not a colony but an overseas province of Portugal, similar to any

41 Adam Malik, 1980, In the Service of the Republic, P T Gunung Agung, Jakarta, p.271.

42 Department of Foreign Affairs, 1984 East Timor After Integration, Republic of Indonesia, p.85.

43 See chapter 4.

44 See chapter 4 .

45 David Jenkins, 1980 "Death of a Dream of Freedom", Far Eastern Economic Review, May 23, p.31. 
other province 46 . The government which succeeded the Caetano regime, the Spinola government, was keen to rid itself of Portugal's costly colonies and supported the right of self-determination for its African colonies and its sole Melanesian colony47.

The Spinola government initiated the decolonisation process by restoring a measure of civil rights in East Timor, dissolving the official Peoples National Action political party, disbanding the secret police, and permitting the formation of political parties 48 . In Dili a Committee for the Selfdetermination of East Timor was established in May of 1974, and in August Portugal declared its willingness to cooperate with the United Nations in the decolonisation process. In doing this, Portugal recognised East Timor as a non-self-governing territory and its own function as the administering power. This established the legal framework which the UN continues to recognise. The United Nations normally does not recognise a new state until independence has been formalised 49 . Because the struggle for independence goes on in East Timor, Portugal is still considered the administering power by the UN.

Portugal has rejected both the request for integration issued by the PGET as well as the unilateral declaration of independence issued by FRETILIN which preceded it by a day. In a letter to the Secretary General of the United Nations, the Portuguese representative at the UN argued that the declaration of independence lay outside of the process of decolonisation initiated by Portugal and therefore endangered the process 50 .

In rejecting both expressions of self-determination, and by withdrawing its administrative personnel following the Indonesian invasion, Portugal has effectively frozen the decolonisation process. It is still considered the administering power by the UN. However Portugal has recently initiated proceedings against Australia over its signing of the Timor Gap Zone of Co-operation Treaty with Indonesia which indicates it considers itself responsible for East Timor. It also indicates Portugal continues to reject as bogus the act of self determination that culminated in East Timor's integration into Indonesia.

46 James Dunn, 1983 Timor: A People Betrayed, Jacaranda Press, Queensland.

47 ibid.

48 Kristiadi, 1986, p.547.

49 Akehurst, 1987, p.298.

50 Letter dated 28 November 1975 from Antonio Da Costa Lobo, Portuguese representative at the UN, reprinted in Department of Foreign Affairs, 1977 Decolonisation in East Timor, p.72. 


\section{The will of the people}

The right to self-determination is recognised as inalienable, even by Indonesia. Self-determination is a continuing process and a choice once made does not bind that group in perpetuity 51 . Even those who accept that it was a genuine act of self-determination which resulted in the annexation of East Timor, cannot deny that the armed struggle represents a renewed call for self-determination.

At the time of the request for integration with Indonesia and the unilateral declaration of Independence issued by FRETILIN, there were undoubtedly conflicting views as to what constituted the will of the people. However the ongoing armed struggle against Indonesia is clear evidence that some Timorese feel their will has not been taken into account and that their right to self-determination has been violated. There are no rules as to how often a process of popular consent must take place, but a protracted war of resistance is a manifest demand for a new act of self-determination.

The armed struggle in East Timor is a logical outcome of the decolonisation process. Without the interruption by the Indonesian military, the process may have come to a peaceful conclusion. The Indonesian invasion cut off all avenues for peaceful resolution of the self-determination debate, leaving armed resistance the only viable option for some. Deprived of other avenues for dissent, the East Timorese have used armed conflict to extend the process.

By its very nature, armed resistance in Timor against Indonesia represents an expression of popular will. Guerilla fighters are as much a creation of political climate and popular aspirations as they are catalysts for the further development of those aspirations 52 . The Timorese guerillas are a part of the civilian population and not professional soldiers. They are dependent on the civilian population for survival, making the struggle engage a large part of the population. In his defence statement, imprisoned resistance leader Xanana Gusmao asserted that the Indonesians refuse to settle the question of East Timor by a referendum because they know they would lose 53 . Jakarta, he claimed, should recognise it has long since lost in East Timor.

51 Lee Buchheit, 1978 Secession: The Legitimacy of Self-determination, Yale University Press, New Haven, p.12.

52 Robert Taber, 1969 The War of the Flea: Guerilla Warfare in Theory and Practice, Paladin, St Albans, p.19.

53 Statement issued on March 27, 1993 in Dili. 


\section{Rejecting Indonesia's claim}

Indonesia's claim to East Timor rests on its assertion that the former Portuguese colony was integrated into the Republic of Indonesia in accordance with the wishes of the East Timorese people as expressed by a representative assembly in a legitimate act of self-determination. However, the legitimacy of the act of self-determination has been rejected by the United Nations on the grounds that Indonesia's actions contravene international law. The annexation of the island nation has also been condemned by the non-aligned movement, of which Indonesia is a prominent member, as well as the former colonial power, Portugal, claiming that it has yet to discharge its duties as the administrating power.

Most importantly however, the formal incorporation of East Timor into the Indonesian Republic has been rejected by many East Timorese who claim they have yet to exercise their right to selfdetermination. That they have this right is beyond doubt. Under international law, as well as by their own perception, the people of East Timor are entitled to freely determine, without external influence, their political status. The international community, as discussed in later chapters, has been unwilling to act on this principle however, and Indonesia is unable, for historical and political reasons, to consider implementing a legitimate act of self-determination in East Timor. 


\section{Chapter 2}

\section{Indonesia's Inevitable Annexation of East Timor}

As a founding member of the non-aligned movement, anti-colonialism is a central tenet of Indonesian political culture. Jakarta thus found itself in a difficult position when decolonisation was initiated in East Timor; whilst ideologically Indonesia was bound to support selfdetermination for the Timorese, to do so was perceived as being potentially threatening to the integrity of the Indonesian state. Jakarta has attempted to reconcile its ideology and action by using anti-colonial rhetoric and the language of decolonisation when discussing the invasion and subsequent annexation of East Timor.

In addition to the influence of anti-colonial ideology and security concerns, the ascendancy of the armed forces in all aspects of Indonesian civil life has had a decisive effect on the development of the Timor conflict. Indonesia's motivations for invading East Timor in 1975 are complex but what is clear is that the invasion was not simply an effort to extend the boundaries of Indonesia 1 . Among the many factors that must be considered when attempting to understand the decision to invade, rather than continue to seek a diplomatic solution, the army's role as self-appointed guardian of the nation's interest is central. Vasquez argues that in traditional International Relations theory, political actors will not resort to violence to achieve their ends if there are more efficient, less costly, and more legitimate ways of attaining their ends ${ }^{2}$. This cost/benefit approach to conflict involves assigning value to means, as well as ends. In Indonesia, the military is a primary political actor and this certainly influenced the value assigned to military intervention as against diplomatic alternatives.

\section{Ideology and politics: the militarisation of government}

The military in Indonesia have become a political force in their own right and are involved in the political process at all levels. Crouch argues that the Indonesian military has always been a political force as it had its origins as a revolutionary army fighting the Dutch, and therefore was amotivated by political concerns ${ }^{3}$. This view is supported by Jenkins, and McGuire and Hering, who suggest that the armed forces emphasise that they first emerged from the people of Indonesia

1 J.A.C. Mackie, 1986 “Does Indonesia Have Expansionist Designs on Papua New Guinea?", in R .J. May (ed), Between Two Nations: The Indonesian Papua Border and West Papua Nationalism, Robert Brown and Associates (Aust) Pty. Ltd., Bathurst, N.S.W., p. 73.

2 John A. Vasquez, "Peace and the New World Order", keynote address to the New World Order Conference, Centre for Strategic Studies, Wellington December 8 - 9, 1994; unpublished.

3 Harold Crouch, 1978 The Army and Politics in Indonesia, Cornell University Press, Ithaca, New York, p. 344. 
rather than being a creation of civilian government, dependent upon it for legitimacy 4 . Rather, it is the state that relies on the armed forces for its continued existence. The involvement of the military in suppressing regional rebellions at the time of the 1957 declaration of martial law, and in suppressing or containing other outbreaks of rebellion since then, confirmed the inherently political nature of the position of the armed forces. By acting in such internal security matters, the army made political choices and became deeply entrenched in civil politics 5 .

The integrity of the modern state of Indonesia can be largely attributed to the tight grip the armed forces maintain on Indonesian politics. There is little room for dissent or the expression of separatist aspirations in Indonesian political life, and therefore limited avenues for the expression of discontent. In the case of East Timor, the pervasiveness of military influence in Indonesian life influenced the initial Indonesian response to the decolonisation process, and shaped the development of the conflict. Foremost among the concerns of the armed forces is the security of the vast and ethnically diverse archipelago that constitutes modern Indonesia. Initially East Timor was treated as a foreign policy issue. After the Act of Parliament that formally integrated the province into Indonesia in 1976, it was considered an internal security issue. An independent East Timor was perceived as a threat. The response to this threat, whilst being couched in terms consistent with Indonesia's anti-colonial ideology, was designed to attain quite a different end. Once the legal integration of the province was achieved, policy was designed to ensure that that situation was not reversed.

\section{Redefining “democracy"}

Having formally become an independent state in 1950, the Republic of the United States of Indonesia went through something of a political identity crisis. Although support for the idea of democracy was almost universal amongst the Indonesian political leadership at the time, it was not necessarily construed as having representative functions, formal opposition, or as being based on majority rule 6 . The principle of democracy was seen as legitimising the new government but the ideals of a Western democratic system were not easily transplanted to Indonesia, whose political

4 David Jenkins, 1984 Suharto and His Generals: Indonesian Military Politics 1975 - 1983, Cornell Modern Indonesia Project, Cornell University, Ithaca, New York, p. 1; G. McGuire \& B. Hering, 1987 "The Indonesian Army: Harbingers of Progress or Reactionary Predators?" in Christine Doran (ed) Indonesian Politics: A Reader, Centre for South East Asian Politics, James Cook University of North Queensland, Australia, p. 205.

5 Michael Vatikiosis, 1993 Indonesian Politics Under Suharto: Order, Development and Pressure for Change, Routledge, London, p. 67.

6 Herbert Feith, 1963 "The Dynamics of Guided Democracy" in Ruth T. McVey (ed) Indonesia, Hraf Press, Yale University, New Haven, p. 313. 
experience to date was of powerful, centralised authority 7 . Feith suggests that the constitutional democratic model was adopted because of a lack of practical alternatives ${ }^{8}$. At the time, the army had yet to emerge as a modern professional force and no cohesive political party existed to take the reins.

After independence, several coalition governments rose and fell rapidly but were unable to sustain political support in the face of a declining economy, widespread corruption, regional rebellion and an increasingly coherent communist party9. A concurrent large scale reorganisation and rationalisation of the armed forces led to the emergence of a modern professional military, very different from the piecemeal force of armed civilians that had fought for independence. A shift in sentiment among landowners, and others with a stake in the economy, away from support for the liberal democratic experiment opened a window of opportunity for President Sukarno who had support in the military. A change to the parliamentary system of government was suggested.

\section{Guided democracy: government by consensus and the transfer of power to the armed forces}

Disenchanted with the apparent instability of the party system, Sukarno began to develop an idea of "Guided Democracy", a system of government by consensus in which all major parties would participate in cabinet. They would sit on a consultative National Council along with representatives from workers, peasants, business and other groups. "Representation" would thus be by functional groups, one of which was the armed forces, rather than by popular vote. This system was presented as reintroducing traditional patterns of authority based on ideas of benevolent leadership, governing by consensus rather than being dictated to by the will of the majority 10 . This form of government was supported by both the Communist party and the military who saw an opportunity to formalise their influence in non-military affairs. Overall, popular participation in political matters remained high; between 1959 and 1965 more than 15 million people joined mass organisations that focused on issues such as land reform, corruption and income distribution 11 .

7 McGuire and Hering ,1987, p. 213.

8 Feith, 1963.

9 Richard Robison, 1993 "Indonesia: Tensions in State and Regime” in Kevin Hewison, Richard Robison \& Garry Rodan (eds), Southeast Asia in the 1990s: Authoritarianism, Democracy and Capitalism, Allen and Unwin, Sydney, p.42; Feith 1963, p.314.

10 Nawaz Mody, 1987 Indonesia Under Suharto, Oriental University Press, London, p. 3.

11 Max Lane, 1994 “Culture of Contempt”, New Internationalist, No. 253, March, p. 9. 
In the end, the declaration of martial law in 1957 following the outbreak of regional rebellions in Sumatra and Sulawesi pre-empted the introduction of Guided Democracy in giving formal recognition to the military's right of participation in political affairs. Through martial law, military leaders acquired enormous power in non-military sectors through the appointment of officers to the cabinet, administration and Parliament ${ }^{12}$. The responsibilities of the army under martial law demanded the development of a political structure within the military, which in turn enabled the army to develop its role as an autonomous political force. Effectively, the armed forces became an operational political party 13 .

Following the suppression of regional rebellions, Sukarno and the military had amassed sufficient influence to introduce Guided Democracy principles and by 1960, the parliamentary model was replaced with a presidential system with Sukarno as head of the unitary Republic of Indonesia14. During this era, the armed forces became firmly entrenched in all aspects of government, justifying their dominant role with references to nationaliat spirit and their role in the revolution that brought Indonesia to independence. Great attention was paid to military-related celebrations and anniversaries in an effort to keep the profile of the armed forces high 15 . This effort was greatly assisted by the continuing conflict with the Netherlands over the future of West Papua, and the 1963 confrontation with Malaysia. The atmosphere in Indonesia was kept tense with talk of a military confrontation, air-raid training and the preparation of militias. These perceived threats to security and the integrity of the archipelago further justified the pervasive role of the armed forces. With most political opposition contained by the functional groups of Guided Democracy, the Indonesian Communist Party (PKI) remained the only major barrier to complete military control.

\section{The dual function of the armed forces}

General A.H. Nasution defined the doctrine of the "dual-function" of the armed forces which is the ideological basis of the military's role in non-military matters. This dual-function promoted the armed forces as a socio-political force, active not only in the military arena but in cultural, religious, economic, social and political spheres 16 . The dual-function was rationalised by General Nasution as a military tactic - the military will fail if limited to military matters. It must also be

12 Lane 1994, p. 9; Jenkins1984, p. 2; Crouch 1978, p. 344.

13 "Forum for Realising the True Sovereignty of the People", Conference, Jakarta, August 22, 1991, Indonesia, No. 53, April, 1992, p. 156; M. Caldwell \& E. Utrecht, 1979 Indonesia: An Alternative History, Alternative Publishing Cooperative Ltd., Sydney, p. 125.

14 Hewison et al ,1993, p.43; Feith ,1963, p.344.

15 Feith ,1963, p. 336.

16 Crouch, 1978, p. 345. 
able to carry out political propaganda and economic warfare if the integrity of the nation was to be ensured 17 .

The relationship between the armed forces and civilian political leaders has never been clearly defined and the role of the armed forces has thus never been limited to military issues. In the military code of ethics established in 1950 at the time of independence, the pre-eminence of the elected government is not explicitly recognised 18 . There has therefore been no constitutional basis on which to challenge military interference in civil affairs. Despite this, the extent of military involvement has been a source of controversy 19 . To protect their position, the armed forces have, since independence, enshrined many of the doctrines that support their non-military functions in law. The doctrines of 'Defence of National Security' and 'Total Security' present the participation of the armed forces in all aspects of Indonesian life as absolutely necessary. Laws such as the 1982 Basic Provisions for the Defence and Security of the Republic of Indonesia which enable the military to perform this role in effect make the government of Indonesia, not withstanding its civilian head of state, a military government.

The armed forces frequently reconfirm their dual function, as in a 1988 document entitled Broad Guidelines for the Nation's Direction which states that "in accordance with the Doctrine of the Defence of National Security, the armed forces of the Republic of Indonesia form the core of the system for maintaining Total Security among the people" and that as such, they constitute a social force in addition to their capacity as a security force 20 . In a sub-section entitled "Defence and Security", the document claims that in implementing its socio-political function, the development of the capacity of the armed forces will be geared towards securing their ability to act as a "stabiliser and dynamicist" of national life and to fill a role as an active participant in national development 21 . Economic development was perceived as the central factor in preventing the dissolution of the new state, and the military presented itself as the only truly national force, capable of transcending the partisan interests of the political parties, to ensure that economic development occurred 22 .

17 cited in McGuire \& Hering, 1987, p. 207.

18 ibid.

19 Vatikiosis, 1993 , p. 70.

20 cited in "Forum for Realising the true Sovereignty of the People", 1992, p. 155.

21 ibid.

22 Crouch, 1978, p. 273; Dorodjatun Kuntjoro-Jakti \& T.A.M. Simatupang, 1987 “The Indonesian Experience in Facing Non-armed and Armed Movements: Lessons from the Past and Glimpses of the Future" in Kusuma Snitwongse \& Sukumbhand Paribatra (eds) Durable Stability in Southeast Asia, Institute of Southeast Asian Studies, Singapore, p.103. 
As a stabiliser and dynamicist, the military maintains an influence in village, provincial and regional politics in order that Total Security is not compromised by local politicking. The doctrines of dual-function and Total Security did not establish this role for the armed forces, it has its roots in the struggle for independence when the nature of the fight made necessary close cooperation between the guerillas and local leaders. The doctrines redefined this relationship in terms of the maintenance, rather than the creation, of an independent state. Threats to the territorial integrity of Indonesia have tended, since the inception of the state, to have come from within its borders rather than from an external aggressor. Thus, security policy is directed at controlling perceived threats, often through forms of 'territorial management' such as the relocation of indigenous populations and the settling of Indonesian migrants in troublesome areas 23 . KuntjoroJakti and Simatupang suggest that the military has been convinced by the relative political and security stability in Indonesia, the conflict in East Timor not withstanding, of the correctness of these doctrines 24 .

\section{President Suharto}

The supreme role of the armed forces was cemented by the transfer of power on the 11th of March 1966, to General Suharto. At this time Sukarno conferred almost unlimited authority on the General. Sukarno had been effectively ousted in the wake of a 1965 coup attempt which the PKI was accused of masterminding 25 . The truth behind the coup attempt of 30 September, and the counter-coup of 1 October that placed Suharto and the armed forces in control, remains murky. While Sukarno survived the coup, six generals did not, suggesting it was not Sukarno but the army leadership that was the target of the coup attempt. Whether it was indeed a PKI plot to check the growing cohesion of the military, the result of internal army rivalry, a plot by a conservative alliance of generals, or a Suharto plan to advance his own position in the armed forces may never be resolved 26 .

23 The transmigration program (resettlement of Javanese) has been widely used in remote parts of Indonesia as a tool for extending military influence down to village level. In border areas, such as the Indonesian - Papua New Guinea border, and other locations where unrest occurs or is expected, the military command structure is supported by the population of transmigration sites with active or retired military personnel and their families. Transmigration has a cultural aspect as well: the program is designed to disseminate the dominant culture, which is Javanese, and encourage the assimilation of minority groups - Mariel Otten, 1986, Transmigrasi: Indonesian Resettlement Policy 1965 - 1985; Myths and Realities, IWIGA Document \#57, Copenhagen;.

24 Kuntjoro-Jakti \& Simatupang, 1987, p.103.

25 Jenkins, 1984, p. 3.

${ }^{26}$ McGuire \& Hering, 1987, p. 208; W.F. Wertheim, 1987 "Fissures in the Girdle of Emeralds" in Doran (ed), p. 66 . 
Longstanding tensions between the PKI and its union supporters, and conservative military and Islamic forces, deteriorated into violence after the coup. The purge of the PKI that followed all but destroyed the party as an effective political force, removing the major check on the military's power as well as destroying Sukarno's base of popular support. Any remaining military support for Sukarno was also purged; thousands of officers and soldiers were arrested, suspended or transferred to parts remote from Java. Commander of KOSTRAD, the Army Strategic Reserve Command, General Suharto, became the new president of the Republic and quickly consolidated his position by appointing personal allies to key posts made vacant during the coup and countercoup 27 . Suharto's position was further strengthened by a streamlining of the armed forces, and an affirmation of the ideology governing the army's role of minimising religious, ethnic and regional divisions in favour of commitment to central government.

By blaming the PKI for attempting to overthrow the government, the armed forces were able to vilify the Communist Party and communism generally, something that military personnel had a great deal of antipathy toward. Simultaneously, they reasserted their own role as guardians of the national interest, supporting this with action taken to prevent a communist takeover and save the government of President Sukarno. The temporary continuation of Sukarno as the head of state legitimised this claim. The orderly and legal transfer of authority from an increasingly less powerful President to the consolidating Suharto leadership kept a veneer of constitutionality over what was as much a coup d'etat as the defeated coup attempt itself had been. The anti-communist fervour that had been whipped up during the purge of the PKI was revived as a weapon against FRETILIN in the months leading up to the invasion of East Timor, and was later used as justification for the invasion.

Conceivably, the army's take-over could have improved the prospects for a return to representative democracy, restoring some of the electoral processes removed under Guided Democracy 28 . In practice however, this did not occur. Military influence continues to permeate the political structure, down to the village level. Although elections are now held regularly in Indonesia, they are carefully managed and their sole purpose has been to legitimise the military-backed government of President Suharto both at home and in the eyes of Indonesia's foreign investors, allies and creditors 29 . Respect for authority and hierarchical structures remains a central tenet of Indonesian political culture. Military ideology reinforces this and ensures there is little room for political activity outside state-defined structures. Legislation compels political parties to embrace the

27 Herbert Feith ,1987 “Political Control, Class Formation and Legitimacy in Suharto's Indonesia" in Doran (ed), p.222.

28 McGuire \& Hering, 1987, p.210.

29 Robison, 1993, p.45; Andrew MacIntyre, 1993, "Indonesia in 1992: Coming to Terms with the Outside World", Asian Survey, Volume 33, No. 2, p. 209. 
national ideology of unity, rejecting separatist or religious values. As East Timor is now considered to be the 27th province of Indonesia, this means that even if an indigenous Timorese party were sanctioned, it would be prohibited from advocating self-government or calling for a referendum on self-determination.

\section{The impact of military rule on the Timor conflict}

The decolonisation process in East Timor was begun at a time when communist governments had recently been established in Vietnam, Laos, and Cambodia. Indonesia's own communist demons still lingered; the purge of the PKI had occurred only ten years previously. All this added to the sense of crisis sparked by the coup in Portugal (seen as taking Portuguese politics to the left of centre) which suddenly made the future of East Timor unclear. Of the emerging Timorese political parties, one of the most popular, FRETILIN, was also seen as being the most leftward leaning 30 . This raised the spectre of a "Cuba-in-the-south", a nest of communist influence, a haven for Indonesian exiles and an example to other provinces with separatist aspirations, right on Indonesia's doorstep ${ }^{31}$. If this were the case, an independent East Timor might have become a source of sedition within Indonesia itself. Furthermore, the political ties established by an independent East Timor may have threatened Indonesia's interests in the region ${ }^{32}$. Mackie argues that a major factor in the decision to intervene was the commitment of military policy-makers to their own anti-communist rhetoric ${ }^{33}$. They were unable to take a longer term view of the situation and to set aside their concerns for the security of Indonesia long enough to consider other options.

Even if the charges of communism proved false and the worst fears of the Indonesian military leaders were not realised, it was clear that the chronically underdeveloped state of East Timor would need outside support to become economically viable ${ }^{34}$. The concern was that if FRETILIN,

30 Heraclides suggests that ideology is one of the great unknowns of separatist or armed resistance movements. He notes that it is generally accepted that whatever the professed ideology of a separatist movement, as a whole they tend to be ideologically ambivalent. This is partly due to the need to accept assistance from any source and partly due to the diffuse ideology of nationalism. The left wing ideology attributed to FRETILIN, and the anti-Indonesianism, was not always supported by events. FRETILIN appears to have been more flexible in its ideological approach than Indonesia and other state governments believed - Heraclides, 1991, p.34.

31 Mackie, 1986, p.75; Crouch, 1978, p.341.

32 Leifer, 1983, p.155.

33 Mackie, 1986, p.75.

34 Exploration of the Timor Gap had not commenced at this stage, and the extensive researves of oil and natural gas had yet to be discovered (see chapter 3). The potential revenue from these resources significantly affects the projected GNP of an independent East Timor. 
perceived as being anti-Indonesian, should emerge from the decolonisation process as the new government, Indonesia would be deprived of an influence in the future direction of the state 35 .

This particular concern seems to have been groundless. After receiving assurances from Foreign Minister Adam Malik in June 1974 that Indonesia would support independence and selfdetermination for East Timor, FRETILIN representative Jose Ramos-Horta told Australian Consul James Dunn ${ }^{36}$, and recorded in his autobiographical account of the conflict, that a FRETILIN government would involve Indonesia in East Timor's foreign affairs and defence policies whilst it took care of domestic affairs 37 . As it was, Indonesia failed to take a long-term view of the situation in East Timor. By neglecting to take an early and active interest in the future of the small Portuguese colony, Indonesia lost its opportunity to have a positive influence the direction of the decolonisation process.

Had Indonesia actively campaigned for decolonisation in East Timor prior to the initiatives of the Portuguese, East Timor may have voluntarily become the 27th province of the Republic, although this seems unlikely, or may have entered into a "free association" arrangement, much as New Zealand has with the Cook Islands, Niue and Tokelau. After all, it was a small state whose economic condition was marginal at best. Statements were made by Generals Nasution and Mokoginta in 1963 that Indonesia would support the East Timorese in their struggle to integrate with Indonesia, the perception being that this is what a Timorese struggle against the Portuguese would seek to achieve, but these statements were not supported with either financial or military assistance 38 .

\section{Archipelagic Outlook}

Indonesia's reasons for seeking the integration of East Timor were thus not an expression of expansionism but an effort to maintain the integrity of the archipelagic state by neutralising any possible threat. As recently as 1973, the Consultative Assembly had reaffirmed the commitment of the government and armed forces to the "Archipelagic Outlook", a doctrine of territorial unity that views the seas and straits of the archipelago as being as much a part of Indonesia's territory as the islands, bridging the physical separation between the different islands, regions and ethnic

35 New Zealand political scientist, Stephen Hoadley, also considered these fears groundless. His arguments are discussed in Chapter 4.

36 James Dunn, former Australian consul to Indonesia and political columnist, in a speech given at Turnbull House, Wellington, June 29, 1994.

37 Ramos-Horta, 1987, p.42.

38 Donald E. Weatherbee, 1966 "Portuguese Timor: An Indonesian Dilemma", Asian Survey, Vol. 6, No.12 p.691. 
groups 39 . The fragmented nature of Indonesia's territory and society made apprehension about a possible threat, particularly a communist threat, all the more acute.

\section{Indonesia and decolonisation in East Timor}

It is ironic that Indonesia, founding member of the non-aligned movement, champion of antiimperialist movements and fierce upholder of the right of colonies to self-determination, should find itself in the position of occupying power in East Timor. Furthermore, the situation is largely one of Indonesia's own making. Prior to the initiation of a decolonisation process by Portugal, it seems little thought had been given as to if, when, and how East Timor might be decolonised. Mackie 40 suggests that those in Indonesia who had considered the subject of decolonisation in East Timor naturally assumed that the Timorese would want to become a part of their large neighbour, particularly as that neighbour shared the same island. Few Indonesians had considered that East Timor may have evolved very differently under Portuguese rule than West Timor had evolved under Dutch and Indonesian rule, or that the East Timorese considered themselves to be a distinct people with a distinct culture that they had every intention of preserving.

Under Sukarno, Indonesian foreign policy was firmly opposed to any continuation of Western influence in former Asian and African colonies. In his 1959 Independence Day address, President Sukarno confirmed that Indonesia was "actively opposed to, and hitting hard at, all forms of imperialism and colonialism wherever they occur"41. This policy manifested itself in the confrontation with Malaysia over apparent British influence, and in the conflict with the Netherlands over West Papua. At the same time, however, little was said or done about the continuing Portuguese presence in East Timor. The colonial regime in East Timor was an anomaly which Indonesia chose to ignore, to all intents, rather than act on.

In fact some thought had been given to the problem of East Timor, albeit not much. Reference to the undesirable Portuguese presence in the region was made by the Vice Chairman of Sukarno's Supreme Advisory Council in 1961 at a protest rally supporting Angolan independence (Indonesia clearly did not feel threatened by the independence of this distant Portuguese colony), and in 1962 by General Nasution who described the situation of the East Timorese as one of enslavement ${ }^{42}$. In spite of these condemnations, little action was taken to change the situation. This was not for lack

\footnotetext{
39 Leifer, 1983, p.143.

40 Mackie, 1986, p.74

41 cited in Weatherbee, 1966, p.683.

42 Weatherbee, 1966, p.689.
} 
of opportunity; continuing skirmishes along the border with West Timor could have been interpreted as provocation had Indonesia sought a pretext for intervention at that time. Instead, Indonesia continued to assert that although it opposed colonialism in East Timor, it made no claim to the territory. It made this position clear to the First Committee of the United Nations General Assembly in 1957, reaffirmed it in an address to the General Assembly in 1960, and continued to assert that this was Indonesia's position in 1974, only a year before the invasion of the territory 43 . Even as it became clear that armed intervention was imminent, Indonesia continued to assert that it had no territorial ambitions but was acting only at the request of the Timorese people 44 .

Defence Chief General Ali Murtopo said in an interview in October of 1975 that "Indonesia is not an expansionist nation and has absolutely no territorial ambitions" 45 . In a sense, these assertions were true. Indonesia did not seek to integrate East Timor because it considered the territory to be an inherent part of Indonesia, or because it was felt that the Timorese were "brothers", although Indonesia later advanced both these reasons to justify its actions. Indonesia's ambitions were territorial only to the extent that by having control over the territory, Indonesia prevented a hostile power, including the Timorese themselves, from establishing itself there.

\section{A security matter}

The dominance of the military in Indonesian government ensured that the security aspect of the situation was kept to the fore. If Indonesia had not attempted a liberation of East Timor from Portuguese colonialism earlier, it was because such action may have endangered Indonesian interests in the region and internationally 46 . With the advent of decolonisation, the perceived potential of an independent East Timor to inflict greater damage on those interests meant that some form of intervention had to be considered. It seems that Indonesia made a decision to integrate East Timor soon after the initiation of a decolonisation process by Portugal, only the means of doing so remained in dispute 47 . By leaving the decision to actively promote the integration of East Timor so late, Indonesia limited its options. Of those avenues open to it,

43 Dunn, 1983, p.103-104; Ramos-Horta, 1987, p. 43.

44 Department of Foreign Affairs, 1984, p.36.

45 Coggin, 1975, p.13.

46 Weatherbee, 1966, p 694. Indonesia's interests included, among others, maritime boundary negotiations with Australia and substantial development assistance provided by the Inter-governmental Group on Indonesia (IGGI).

47 Keith Suter, 1978 “The Conquest of East Timor”, Contemporary Review, Vol. 232, No. 1346, March, p.138; Nichterlein, 1977, p.486; Leifer, 1976, p.348; Coggin, 1975, p.10. 
Indonesia has taken several. Whilst a forcible annexation of the territory was clearly an option from the beginning, the cost of a military operation was formidable, both financially and politically. President Suharto's authority was derived from his ability to deliver on promises of economic development; an unfavourable response to an invasion of East Timor from Indonesia's creditors, or an impression of instability that such an invasion might create, would threaten Suharto's position. Although the military influenced the decision to work towards the integration of East Timor, military means were not initially seen as the most suitable method of achieving this aim. A political solution was sought which would negate the need for military intervention.

The decolonisation process led to the formation of political parties in East Timor. Of the parties that emerged, only one was firmly in support of integration with Indonesia. Whether the Popular Association for a Democratic Timor (APODETI) was created at the behest of Indonesia, or whether it spontaneously supported integration, is not clear from the available literature on East Timor. What is clear is that the party attracted the support of Indonesia, although not the popular support of the Timorese. Although Indonesia claimed otherwise, APODETI supporters might have been counted in hundreds, but never in thousands 48 . Indonesia's enthusiastic support for APODETI as a way of voluntarily integrating East Timor backfired; one of the motivations for a coalition between the Timorese Democratic Union (UDT) and FRETILIN was apprehension at the possibility of intervention in support of APODETI 49. The breakdown of the coalition hurtled East Timor toward civil war and removed any chance of peaceful integration of the territory. In the early stages of decolonisation, neither of the two political parties that attracted the bulk of popular support, UDT and FRETILIN, were advocating integration. It soon became apparent that East Timor would not become a part of the Republic within the framework of decolonisation.

There was some tension between those who continued to advocate a negotiated settlement, notably Foreign Minister Adam Malik whom FRETILIN representatives had found reassuring, and those who preferred to take more decisive action. Ultimately policy was determined by the armed forces. Defence Minister General Panggabean warned that Indonesia would not hesitate to take action if the situation in East Timor threatened the stability of the region50. A military presence had been building up along the border with West Timor for some time, but negotiation with Portugal and the Timorese political parties continued. Pressure for a military solution reached its peak after the collapse of the FRETILIN-UDT coalition and subsequent civil war. In October of 1975 when the civil war was entering its fifth week, Coggin believed regional and international support was

\footnotetext{
48 Dunn, 1983, p.71; Nichterlein, 1977, p.487.

49 Nichterlein, 1977, p.350.

50 Crouch, 1978, p. 340 .
} 
quietly in favour of armed intervention51. Australian Prime Minister Gough Whitlam had made his position quite clear; he did not consider an independent East Timor either viable or desirable and had indicated that Australia would not look unfavourably on armed intervention ${ }^{52}$. The United States had similarly indicated that they would not protest an Indonesian incursion into East Timor 53 . Assured of support for a military response, Indonesia had only to find an acceptable reason for entering the territory.

Indonesia was provided with a legitimate excuse for intervention when Portugal rejected FRETILIN's unilateral declaration of independence. Portugal's failure to confer legitimacy on the FRETILIN government meant Indonesia could argue that the rights of the other parties in East Timor had been denied and that intervention was needed to protect the bulk of the population from FRETILIN atrocities 54 . On 7 September, 1975, following FRETILIN's victory in the brief civil war, the other four parties, UDT (recently persuaded to seek integration), Kota, Trabalhista and APODETI, jointly presented a petition to Indonesia requesting integration. This, and a later declaration of integration by a hastily assembled Peoples Assembly, was the basis of Indonesia's claim that FRETILIN's claim of independence did not represent the will of the majority 55 .

From Indonesia's standpoint, the declaration of independence had closed all avenues for a peaceful solution. Portugal's rejection of the declaration legitimised Indonesian arguments that the declaration was not a valid result of decolonisation. Indonesia argued it had "a moral obligation to assist the people of East Timor and to ensure the decolonisation process could be implemented in accordance with the ideals and wishes of the entire population of the territory"56. The statement added that Indonesia would take whatever steps it decreed necessary to safeguard Indonesian sovereignty and territorial integrity. As East Timor had never been a part of Indonesian territory, its independence was not a threat to the integrity of the Indonesian state per se. Rather, this statement, made a week before the invasion, indicates that an independent East Timor was considered provocative to separatist movements in Indonesia. The establishment, and survival, of a small island state would demonstrate the possibilities of political independence, and possibly become a political ally or refuge for separatist movements.

51 Coggin, 1975, p.10.

52 Taylor, 1991, p.32.

53 Torben Retboll , 1987 "The East Timor Conflict and Western Response", Bulletin of Concerned Asian Scholars, Vol. 19, No. 1, Jan-March, p.30; Dunn, 1983, p.347-350.

54 Department of Foreign Affairs, 1984, p.49.

55 ibid, p.47.

56 ibid., p.47. 
During the civil war Portugal had evacuated its administrative personnel to the island of Atauro off the coast of Dili. By December 8, Portugal had withdrawn its personnel from East Timor entirely. As the Indonesian army ransacked Dili, the Portuguese were sailing toward Darwin. Indonesia saw this as an abdication of responsibility by the administering power, the denial of any further claim to sovereignty and a green light for the formal of incorporation of the territory. Dunn argues that the Portuguese did not abandon their post but were forced out and that Portuguese sovereignty over the territory remains intact 57 . In that case, Portugal's consent, itself dependent on the consent of the Timorese, would have been required for formal integration to take place. By refusing to recognise continuing Portuguese sovereignty, Indonesia did perceive any further barriers to the incorporation of East Timor into the Republic. A 1981 television documentary screened in Portugal implied that the Portuguese government had acquiesced in the integration during secret talks with the Indonesians held in Hong Kong in June 197558. The Socialist Party, which formed the government at that time, denied these allegations. Whether there is any truth behind these claims or not, no formal recognition of the integration of East Timor by Portugal was forthcoming.

57 Dunn, 1983, p.290. The argument that Portugal abandoned its colony and thereby forfeited its role as administering power was raised by Australia before the International Court of Justice in the Timor Gap case; see chapter 3 .

58 Retboll, 1983, p.60. 


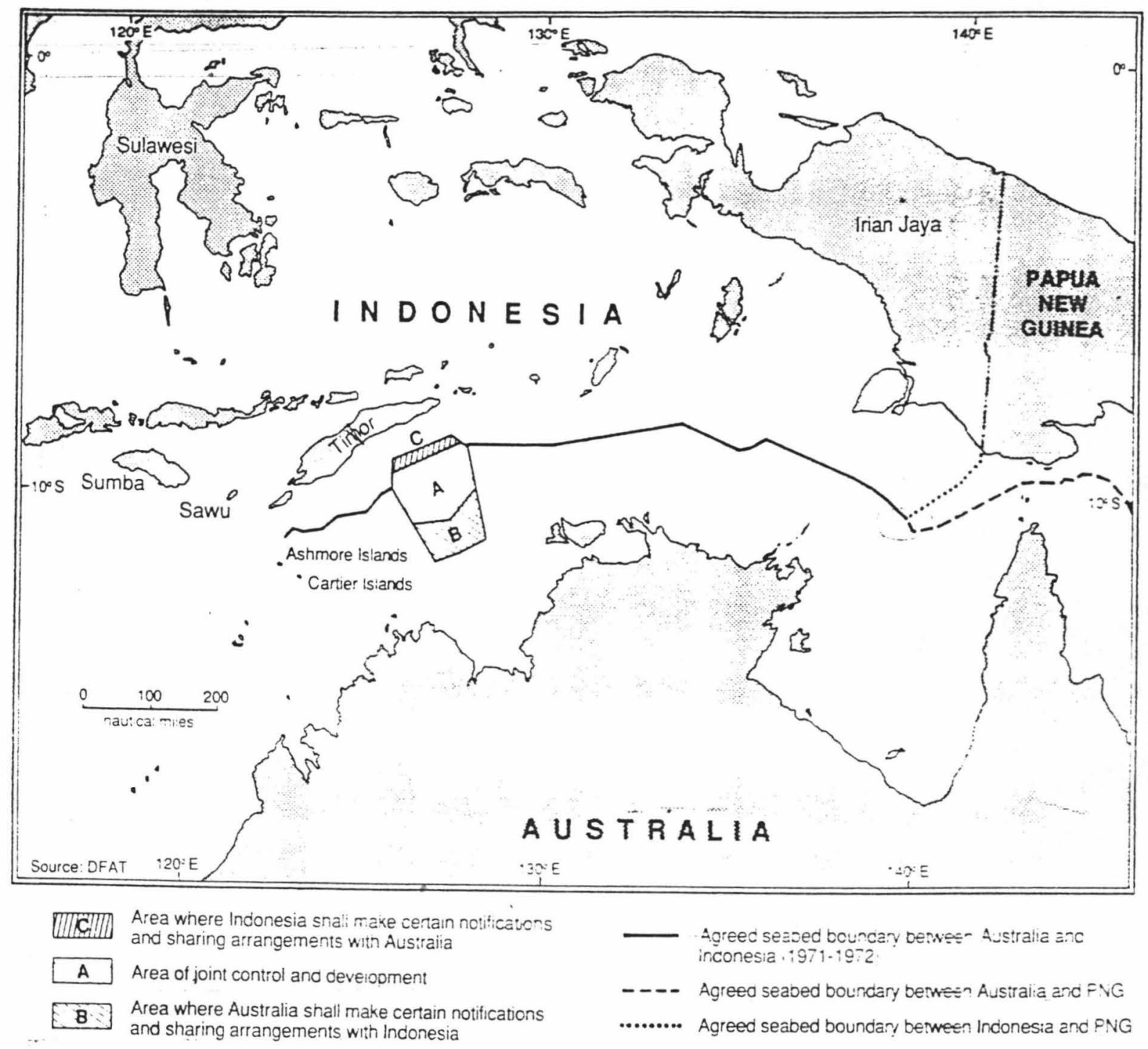

Source: Australian Journal of International Affairs, Vol. 45, No. 2, 1991, p. 171 


\section{Chapter 3}

\section{Australia, Indonesia and East Timor.}

Australia and Indonesia are profoundly different in terms of history, language, population and political and social cultures, yet their geographical proximity has forced them into an intimate relationship which requires significant cooperation and compromise. Indonesia is Australia's 11th largest trading partner, and the second largest amongst the ASEAN countries. The total volume of trade is worth more than $\mathrm{A} \$ 3$ billion, and has almost tripled in the past five years; Australian exports, including crude oil, wheat, aluminium and cotton, are worth almost $\mathrm{A} \$ 2$ billion annually ${ }^{1}$. Australia is also a prominent investor in Indonesia, notably in the mining industry.

Mining and petroleum interests in the Timor Sea have forced Australia to confront the issue of East Timor's ambiguous sovereignty. Apprehension about the territorial ambitions of its large and powerful neighbour were put aside when Australia entered into treaty negotiations over the gap in the maritime boundary south of East Timor. This step required Australia to extend de jure recognition to Indonesian rule there, overriding previous reservations about the legality of such rule. Indonesia welcomed this belated recognition of its position in East Timor, and the opportunity to share in the exploitation of an estimated 5 billion barrels of oil in the Timor Sea ${ }^{2}$.

Australia and Indonesia concluded the Timor Gap Zone of Cooperation Treaty in 1989. The legality of the Treaty was challenged by Portugal which alleged that as it has yet to discharge the responsibilities of administrative authority through an internationally recognised act of selfdetermination, it should have been party to the negotiations. Portugal brought the case before the International Court of Justice which drew it firmly back into the Timor sovereignty debate. The case highlighted Australia's relationship with Indonesia and its response to the conflict in East Timor.

The existence of the Timor Gap Zone of Cooperation Treaty is indicative of the ambiguity of the status of East Timor in the international community. According to its parties, the Treaty is a legal and binding instrument. It is considered a violation of East Timor's sovereignty and Portuguese authority by its detractors. Regardless of viewpoint, the treaty prompted a re-examination of sovereignty, self-determination, aggression and state obligation as understood in international law; and of the legality of a treaty which disposes of the resources of a people whom the United Nations considers non-self-governing.

\footnotetext{
1 John Hamilton, 1995 “Suharto: The Puppet Master”, Herald Sun, July 1, p. 23.

2 In Cold Blood - The East Timor Massacre, Yorkshire Television, 1992.
} 


\section{The Timor Gap Zone of Cooperation Treaty}

The Timor Gap Zone of Cooperation Treaty was signed on December 11, 1989 by Australian Foreign Minister Gareth Evans and his Indonesian counterpart Ali Alatas aboard a Royal Australian Airforce Jet as it flew across the gap in the Indonesian-Australian maritime boundary to the south of East Timor ${ }^{3}$. Described by Gareth Evans as symbolising "the spirit of practical cooperation and friendship" 4 which has characterised Indonesian-Australian relations, the treaty is unique in that pending the permanent delimitation of the seabed boundary, it creates an zone of joint jurisdiction 5 . The treaty overcomes differences of opinion between the parties as to the criteria for delimiting the boundary and enables both Australia and Indonesia to explore and exploit the resources in the Timor Gap, and share in the profits.

The zone is divided into three sections: a northern section for exclusive exploitation by Indonesia, a southern section for exploitation by Australia, and a central section, straddling the boundary where the eastern and western parts of the permanent maritime boundary join across the gap, is for joint exploration and exploitation by Australia and Indonesia under the aegis of a Ministerial Council. Representation on this council includes the Australian Foreign and Resource Ministers, with their Indonesian counterparts, namely the Foreign Minister and the Mines and Energy Minister.

The two states took more than ten years to reach this agreement; the nature of the arrangement means implementation of the treaty provisions will not always be smooth, as Fonteyne points out:

the arrangement could be seen as somewhat less than ideal (it certainly represents a substantial compromise, for each side, of what it believes it is legally entitled to) and will, more than likely not, lead to episodic operational difficulties, given the legal, fiscal, economic, and political disparities between the two partners. 6

Neither Australia nor Indonesia have publicly articulated misgivings about the arrangement however, and Gareth Evans has characterised the treaty as "a creative solution to the kind of

3 "Timor Gap Treaty: Timorese Refugees Challenge the Commonwealth of Australia", Matebian News, Vol. 1, No.3, June 1993, p. 1.

4 Gareth Evans, 1991 "Australia-Indonesia Ties: Timor Gap Zone of Cooperation", Department of Foreign Affairs Monthly Record, Feb 1991, p. 45.

5 Australian Department of Foreign Affairs and Trade, 1989 Annual Report 1988-89, p. 89.

6 Jean-Pierre L. Fonteyne, 1991 "The Portuguese Timor Gap Litigation Before the International Court of Justice: A Brief Appraisal of Australia's Position", Australian Journal of International Affairs, 45:2, p. 170. 
problem which has often led to conflict elsewhere"7. Unfortunately the treaty is not only creative in its allocation of resources, it is has also created a sovereign jurisdiction where none existed before.

\section{The negotiating background}

In $1972^{8}$ Australia negotiated a maritime boundary with Indonesia, leaving a gap to the south of East Timor. Australia had attempted to close the gap through negotiations with Portugal, then accepted by Australia as the administering power of East Timor, but these did not go well. Each party sought to define the boundary by different criteria: Australia according to the 1958 Geneva Convention of the Continental Shelf, and Portugal according to the 1958 Geneva Convention on the Territorial Sea and Contiguous Zone ${ }^{9}$.

Australia claims jurisdiction over its adjacent continental shelf, the Sahul shelf, to a distance 96 kilometres from the coast of East Timor, more than $320 \mathrm{kms}$ from the Northern Territory coast. Here, the Timor Trough stretches $800 \mathrm{~km}$ between Timor and North West Australia and is up to 3400 metres deep 10 . This geomorphological feature was at the heart of the Australian claim as its existence, Australia claimed, clearly demarcates the edge of the Australian continental shelf; the principle of natural prolongation of the shelf taking precedence over claims made by Portugal, and later Indonesia, that all countries are entitled to jurisdiction over 200 nautical miles from the coast, or to a median point in a case such as that of East Timor, where the opposite coastlines are less than 400 nautical miles apart ${ }^{11}$. Portugal refused to concede the median line and negotiations had ground to a halt by 1969 . To emphasise its unwillingness to agree to any boundary demarcation other than a median line, the Portuguese government issued a decree in November of 1969 which stated:

Unless an agreement has been concluded with a state whose coasts are adjacent or opposite to those of the Portuguese State, and providing that no special circumstances justify a different boundary line, the boundary of the continental shelf is the median line, every point of which is equidistant from the nearest points of the baselines from which the breadths of the respective territorial seas are measured. 12

7 Gareth Evans, 1993 Cooperating for Peace: the Global Agenda for the 1990s and Beyond, Allen \& Unwin, St Leonards, p. 42.

8 R D Lumb, 1981 "The Delimitation of Boundaries in the Timor Sea", Australian Yearbook of International Law, Vol 7, p. 73; this supplemented an earlier 1971 agreement.

${ }^{9}$ Sections I and IV respectively of the Law of the Sea, UN Doc.A/Conf.13/L.52-L.55

10 Keith Suter, 1993 "Timor Gap Treaty: The Continuing Controversy", Marine Policy, July, p. 299.

11 Suter ,1993, p. 300; Lumb, 1981, p. 72.

12 ibid 
At the time this decree was made, Portugal regarded East Timor as an integral part of the Portuguese state and this decree therefore impinged directly on the Australian boundary claims. Although Portugal now recognises East Timor as a non-self-governing territory, it remains the titular administrative power and claims it should be party to any discussions intended to delimit the maritime boundary. However, even before the decree was issued, Portugal seems to have put only limited resources into negotiating a maritime boundary with Australia. Suter ${ }^{13}$ suggests that Portugal was content to await the outcome of the Third United Nations Conference on the Law of the Sea (UNCLOS) in the hope that this might clarify the criteria needed to consider in the delimitation of maritime boundaries between opposite or adjacent states. Talks were revived in 1971 but proved unsatisfactory. By the time UNCLOS deliberations assumed treaty form in 1982 , Portugal was excluded from negotiations on the maritime boundary in the Timor Gap. Australia had chosen to negotiate with Indonesia instead.

Portugal's changed attitude toward East Timor, from regarding it as an overseas province integral to the metropolitan state to regarding it as a non-self-governing territory, did affect Portugal's attitude toward the maritime boundary negotiations. Expecting the initiation of a decolonisation process in East Timor, Portugal reasonably assumed that the government of an independent East Timor would negotiate with Australia in its own right. The Indonesian invasion signalled not only the end of the Portuguese-implemented decolonisation process, but the end also of Australia's interest in further negotiations with Portugal.

Martin and Pickersgill 14 suggest Australia abandoned negotiations with Portugal because it was anxious to begin exploration of the sea-bed and exploitation of its mineral reserves. Access to these required clear title. In the wake of Indonesia's annexation of East Timor, it was apparent that neither Portugal nor the self-declared provisional government of East Timor had sufficient control over the territory to negotiate a treaty giving title to the resources in the Timor Sea, thereby determining future rights and obligations under international law. Indonesia appeared to entrench itself as the governing authority, assuming the power to negotiate access to the seabed.

Discussions to close the Timor Gap proved far more complicated than those which led to the 1972 Indonesia-Australian boundary. Then, Indonesia conceded the principle of natural prolongation of the continental shelf. The boundary, which excludes the Timor Gap, gives Australia control of around 70 percent of the seabed between the coast of the Northern Territory and that of West

13 Suter, 1993, p. 299

14 William Martin and Dianne Pickersgill, 1991 "Recent Developments: The Timor Gap Treaty", Harvard International Law Journal, Vol. 32, p.580. 
Timor. Australia conceded around 1350 square nautical miles of the continental slope, but this does not represent a substantial concession to Indonesia's demands for a boundary based on the median line 15 . The boundary was clearly defined and no cooperation across the boundary was called for. In the Timor Gap negotiations, Indonesia took a more aggressive stance. More than ten years were needed to formulate the Timor Gap agreement. Mills suggests this indicated dissatisfaction on the part of Indonesia with the existing maritime boundary - the area appears richer in minerals than Indonesia was aware at the time of the earlier boundary negotiations 16 .

\section{Formal recognition of Indonesian rule}

When the Fraser government began negotiations with Indonesia in 1979, it took the unprecedented step of extending de jure recognition to Indonesian rule of East Timor. Although it "remained critical of the means of incorporation", Foreign Minister Andrew Peacock said Indonesian rule in East Timor was a reality with which Australia must come to terms 17 . Having recognised Indonesian jurisdiction, the Australian government no longer felt it necessary to include Portugal in the boundary negotiations. According to both Australia and Indonesia, Portugal's legal relationship with East Timor had ceased. This position contradicted UN General Assembly and Security Council resolutions passed after the Indonesian invasion which affirm Portugal's role as administering authority. No other state has extended formal recognition to Indonesian jurisdiction in East Timor although many maintain relations with Indonesia as though they had.

Australia's decision to conclude the Timor Gap treaty with Indonesia, recognising its sovereignty over Timor's resources, has significant legal and political ramifications. As Bot notes, nonrecognition of a state is no longer automatically associated with an absence of bilateral relations. Normal treaty relations, indistinguishable from those with recognised states, are maintained with unrecognised governments 18 . However, in this instance Australia's action had alienated a third party. Portugal protested Australia's action before the International Court of Justice (ICJ), arguing that Australia is obliged "to refrain from any negotiation, signature or ratification of any agreement with a State other than the administering Power"19. By negotiating with Indonesia

15 Lumb, 1981, p.74.

16 Andrew Mills, cited in Geoffrey C. Gunn 1994, A Critical View of Western Journalism and Scholarship on East Timor, Journal of Contemporary Asia Publishers, Australia, p.90.

17 Andrew Peacock, Minister of Foreign Affairs, cited in Australian Department of Foreign Affairs Annual Review 1978, p.29.

18 B.R. Bot 1968, Non-Recognition and Treaty Relations, Oceana Publications Inc, Dobbs Ferry, New York, p.244.

19 "Portugal vs. Australia, Cases Before the Court", International Court of Justice Yearbook 1992-93, p.170. 
Australia ignored this obligation. Portugal regards the treaty as "violating the right of the people of Timor to self-determination and their sovereign right to their resources" 20 as well as disregarding Portugal's status as administrator.

\section{The International Court of Justice}

The International Court of Justice is the principal judicial organ of the United Nations. It is the successor to the Permanent Court of International Justice and its statute is an integral part of the UN Charter ${ }^{21}$. Thus, all UN member states are parties to the statute of the ICJ and can be parties to cases before it, but can reject its jurisdiction in all, or some, instances or areas of law. Article 36 of the Court's statute allows states to recognise as compulsory ipso facto the jurisdiction of the Court, or to recognise that jurisdiction only on condition of reciprocity of another state, or for a limited period of time 22 . Fewer than a third of UN members have accepted compulsory jurisdiction in all instances 23 . Other states exclude themselves from accepting jurisdiction in some, or all, cases. Indonesia does not accept the jurisdiction of the Court under Article 36 (2) nor does it accept Portugal's claim to East Timor and the grievance arising from it.

The Court has two types of proceedings: advisory opinions which enable UN bodies to seek clarification of a legal question; and litigation, in which the Court will preside over disputes between states, delivering a ruling which is binding but rarely enforceable. Both types of proceeding require the Court to define and interpret international law, and it is through Court proceedings that the law of the international community is clarified. Portugal's application to the Court invited clarification of several legal issues of current importance, notably the obligation of states not to extend recognition to political entities which were formed by an act of aggression; and the principle of self-determination. Herein lay the weight of Portugal's case.

Litigation may be brought before the Court by prior acceptance by both parties of the compulsory jurisdiction of the Court (acceptance of Article 36(2)), as was the case in the Timor Gap

20 From Portugal's submission to the International Court of Justice, cited in Martin and Pickersgill, 1991, p.579.

21 Charter of the United Nations, Chapter XIV, Article 92; Statute of the International Court of Justice, Article 1.

22 Article 36 (2) and 36 (3)

23 Evan Luard and Derek Heater, 1994 The United Nations: How it Works and What it Does (2nd ed), MacMillan, Basingstoke, p.91. 
litigation 24 ; by the defendant agreeing to accept the writ of the Court; under a treaty clause which provides for referral of disputes to the ICJ; or by special agreement between parties. All these methods rely upon the consent of the parties involved and the Court will not deliver a judgement without it. Unless Indonesia had reversed its position regarding the competence of the Court, it could not have been be named as a defendant in the case. Though the case did not address Indonesia's transgression directly, if the Court had ruled in Portugal's favour, the illegality of Indonesia's annexation would have been implied.

To avoid questions regarding Indonesia's lack of consent, Lisbon was careful to direct its complaint against Australia specifically. However, Lisbon's claim that Australia violated an obligation not to recognise Indonesia's annexation of Timor would have required the Court to assess the legality of Indonesia's action. Australia pointed out that without Indonesia's consent, the Court had no authority to rule on Indonesia's actions 25 . As hearings began in the case, Australia reiterated that Lisbon's real dispute was with Jakarta and that the case should have been brought against Indonesia 26 . A precedent for the Court to overturn Australia's objection was set in the 1986 Case Concerning Military and Paramilitary Activities in and Against Nicaragua. The Court rejected an objection by the United States that the absence of third parties implicated in the case meant the Court could not adjudicate, arguing the third parties were not 'truly indispensable'27. In the Timor Gap case however, the Court considered Indonesia's consent was necessary. The Court ruled by a 14 - 2 majority that its statute barred it from ruling on Portugal's suit as it would first have to judge the legality of Indonesia's presence in East Timor, which it could not do without Indonesia's consent 28 .

Australia viewed the Court's decision as a vindication of its position. Senator Evans said: "It just puts beyond doubt the status of the Timor Gap Treaty"29. In fact, the Court made no comment on the status of the Treaty. Portugal's case was rejected for procedural reasons, not for substantive

24 In its application to the Court to institute proceedings against Australia, Portugal referred to the Declarations made by itself and Australia under Article 36 (2) in establishing the jurisdiction of the Court.

25 Sasha Stepan ,1992 "Portugal's Action in the International Court of Justice Against Australia Concerning the Timor Gap Treaty”, Melbourne University Law Review, Vol. 18, p.920.

26 "Portugal Says Timor Oil 'Tainted With Blood'", Reuters News Service, January 30, 1995.

27 Roger S. Clark 1992, "Timor Gap: The Legality of the Treaty on the Zone of Cooperation in an Area Between the Indonesian Province of East Timor and Northern Australia", Pace Yearbook of International Law 1992, p.85.

28 Andrew Kelly, 1995a “Australia Wins World Court Ruling in Timor Oil Row”, Reuters News Service, June 30.

29 Gareth Evans, 1995, “Australian Foreign Minister on International Court Ruling on Timor Gap Treaty”, Radio Australia, 1100 GMT, July 4. 
ones. In its ruling, the Court emphasised that East Timor remained a non-self-governing territory and that its people retain the right to self-determination ${ }^{30}$. Thus, the Court indicated that the international community does not accept the claims of Indonesia and Australia that East Timor is de jure a part of Indonesia. Until East Timor's legal status is resolved, the legality of the Timor Gap Treaty is dubious at best.

\section{Before the Court}

In its case before the ICJ, Portugal argued that the conclusion of the Timor Gap Zone of Cooperation Treaty breached Lisbon's rights as administering power of East Timor, as well as the East Timorese right to self-determination and sovereignty over Timor's natural resources 31 . Portugal also alleged that Australia is obliged by UN General Assembly and Security Council resolutions taken at the time of the invasion, and in the years following, to recognise Portuguese authority over the territory, thereby rejecting Indonesia's claim to have jurisdiction over the resources in the Timor Sea.

Portugal's case appeared fairly straightforward: decolonisation was being carried out under the auspices of the UN; Indonesia had committed an act of aggression against another state (at the time, Portugal); UN resolutions had condemned the invasion and called for the immediate withdrawal of Indonesian forces. It seemed clear that Australia had infringed international law in recognising Indonesian sovereignty over East Timor, and that the Timor Gap treaty, which flows from this, was likewise illegal. The case was not so simple however. Australia raised many complicating issues and was likely to have raised others had the case proceeded.

Stepan suggested Australia might have argued before the Court that the reality of Portugal's position as administrator of East Timor was a legal fiction 32 ; the practical reality of Indonesian control gave Jakarta's claim legal weight. However, the argument that the government in control of a territory should be recognised as sovereign could easily have been countered by Lisbon which may have claimed Indonesia does not have (nor has it ever had) complete control over the territory 33 . In spite of Indonesian claims to the contrary, evidence continues to emerge that FALANTIL, the armed wing of resistance group FRETILIN, controls large sections of East

30 Kelly, 1995a.

31 ICJ Yearbook 1992-93, p.168-170.

32 Stepan, 1992, p.922

33 Martin \& Pickersgill ,1991, p.580. 
Timor's interior and that Indonesian troops stationed in East Timor are still waging war against them ${ }^{34}$.

The retreat of the Portuguese administration to Atauro during the civil war in 1975, and its evacuation during the Indonesian invasion, invites speculation as to whether Portugal abdicated responsibility for its former colony at that time. Fonteyne argues that whether:

such legal status as the initial United Nations resolutions may have provided, could be regarded as having been preserved in the face of nearly ten years of United Nations neglect of the situation and the reality of Indonesian control for over fifteen years, is highly doubtful. 35

The delay between Australia's recognition of Indonesia's annexation in 1978, and Portugal's registering of a diplomatic protest in 1985, was considerable and cast doubt on the sincerity of Portuguese concern over the matter. Martin and Pickersgill 36 suggest Australia might have argued before the Court that it never recognised Portuguese interest in East Timor prior to the Indonesian takeover but its own attempts to negotiate an agreement over the Timor Sea prior to the Indonesian takeover negate this.

Portugal's capacity to act in this matter stemmed from Security Council Resolution 384 of 197637 which called on Portugal to co-operate with the UN to bring about self determination for the East Timorese. The right of self-determination being understood as perpetual, and recognised by the Court in its ruling, the time delay between the commencement of negotiations and the lodging of a protest was irrelevant to the case. Indeed, Portugal's protest was launched two weeks after the domestic implementation of the Treaty in Australia. Stepan argues that until the treaty was implemented, no violation of Portuguese rights had occurred, and therefore no significant time delay 38 .

Portugal's rights were less central to the case than those of the East Timorese, on whose behalf Portugal brought the suit. The structure of the UN and its agencies means that nations which have not achieved statehood cannot petition the Court directly; they must act through a member state or

34 Reports of military and resistance activity are published regularly by non-governmental organisations, newspapers and official sources; for example, see Michael Casey "Soldier's Diary Tells of War in the Field", West Australian, December 17, 1994, p.6-7; Jill Joliffe "Jakarta Launches New Offensive" Sydney Morning Herald, August 26, 1994, p.10.

35 Fonteyne, 1991, p.42

36 Martin and Pickersgill, 1991, p.580

37 cited in Stepan, 1992, p.920

38 ibid 
UN agency. Portugal thus acted not only on its own behalf as administering power of East Timor, but as a representative of the East Timorese people. Fonteyne suggests:

the United Nations and, ultimately, the world community, by reference to the alleged violation by Australia of the East Timorese people's rights of selfdetermination and permanent sovereignty over natural resources 39 .

The outcome of the case, and the opinion of the court, would have given insight into the current status of Timor's sovereignty, and in so doing, delimit the right of self-determination as it stands in international law today. As the state which bears international responsibility for East Timor, it is appropriate that Portugal brought the case before the Court.

\section{Canberra's Pragmatic Approach}

In developing a relationship with Indonesia regarding East Timor and its resources, Australia appears to have ignored some customary international law, of which the 1970 Declaration on Principles of International Law Concerning Friendly Relations and Cooperation Among States may be considered. Australia was active in the seven year drafting process of this Resolution and co-sponsored it when it was introduced into the General Assembly40. It was adopted unanimously and sets forth the principle that "no territorial acquisition resulting from the threat or use of force shall be recognised as legal"41. In addition to the declaration on Friendly Relations, the 1974 Resolution on the Definition of Aggression states that "no territorial acquisition or special advantage resulting from aggression is or shall be recognised as lawful" 42 . Both resolutions establish propositions of international law or of international treaty law and, as Clark has suggested, represent an authoritative interpretation of the UN Charter 43 .

Parties to treaties and negotiated instruments such as the Declaration on Friendly Relations intend that they should have legal consequences in the form of legal obligations. As a sponsor of that Declaration, Australia clearly intended that it be bound by the obligations resulting from it, yet instead denies that it is. Gareth Evans questions the relevance of the Declaration on Friendly Relations to East Timor's situation, saying:

39 Fonteyne, 1991, p.173

40 Clark, 1992, p.76-77.

41 UNGA Res. 2625 (XXV)

42 General Assembly Resolution 3314 (XXIX), Article 5 (3)

43 op cit 
There is no binding legal obligation not to recognise the acquisition of a territory that was acquired by force. Such a recognition does not, of course, imply approval of the circumstances of the acquisition. In international law the legality of the original acquisition has to be distinguished in subsequent dealings between the state acquiring that new territory and other states - in this instance, Australia. 44

Fonteyne supports Evans' assertion that there is no binding legal obligation not to recognise Indonesian acquisition of East Timor, arguing "non-recognition of 'illegal situations' is highly debatable" 45 . Clark, however, argues that the Declaration on Friendly Relations represents either a customary rule of law or an authoritative interpretation of the UN Charter and should therefore have the full force of international law46. Clark is supported in this view by Stepan and Suter, and by legal precedent in the Advisory Opinion Concerning Namibia. The ruling, delivered by the ICJ in 1971, stated that states were obliged to refrain from entering into treaty relations with South Africa in cases where it purported to act on behalf of Namibia 47 . Stepan writes:

This ICJ opinion on Namibia is clearly analogous to the East Timor situation, where Indonesia maintains a continued illegal presence and Australia has entered into treaty relations with Indonesia in respect of an area pertaining to East Timor's interests. 48

Although South Africa's presence in Namibia had been established under a legal frame work (that of mandated trust territories), South Africa's position at the time this opinion was delivered was similar to that of Indonesia - it maintained a presence there in contravention of international law and in spite of condemnation by the UN. Although international hostility toward the apartheid policies pursued by South Africa were a factor in this condemnation, and far outweigh hostility toward Indonesia's policies in East Timor, the legal issues are similar.

The decision to abandon the principles espoused in the Declaration on Friendly Relations and deny the existence of an international duty not to recognise Indonesia's acquisition of East Timor is characteristic of Australia's response to the conflict since it first erupted. Australia's has consistently reacted in favour of practical realities at the expense of moral and legal principles

44 Hansard, Senate (Australia), 1 November, 1989, cited in Clark 1992, p.78.

45 Fonteyne, 1991, p.177.

46 Clark, 1992, p.81; Article 38 of the Statute of the International Court of Justice directs it to apply "international conventions...establishing rules expressly recognised by the contesting States;" and "international custom, as evidence of a general practice accepted as law".

47 Stepan, 1992, p.924; Suter, 1993, p.301; ICJ Rep 16 [1971]

48 Stepan, 1992, p.925 
involved. This especially true of the Timor Gap issue as this 1975 quote from the Australian Ambassador to Indonesia, Richard Woolcott, indicates:

\begin{abstract}
It would seem to me that [the Department of Minerals and Energy] might well have an interest in closing the present gap in the agreed sea border and this could be much more readily negotiated with Indonesia than with Portugal or independent Portuguese Timor. I know I am recommending a pragmatic rather than a principled stand but that is what national interest and foreign policy is all about. 49
\end{abstract}

\title{
Australia's support for self-determination
}

When Portugal first initiated decolonisation procedures in East Timor in the wake of the 1974 Lisbon coup, Australian government policy was to support self-determination for the East Timorese 50 . Australia's initial response to the invasion was critical, and it supported the first UN General Assembly Resolution of December 12, 1975, calling for a withdrawal of Indonesian troops, although it did abstain from the paragraph deploring Indonesia's military intervention 51 . This position changed as it became clear that Portugal was not going to play an active part in the decolonisation process and incorporation into Indonesia came to be seen as the 'tidiest' solution to the decolonisation problem 52 .

In the United Nations, Australia's position of qualified support reverted to one of abstention in following resolutions; in 1976 and 1977 on the grounds that the resolutions suffered from defects and in 1978 on the grounds that the resolution did not reflect a realistic appreciation of the situation in East Timor and no practical purpose was served by it. In 1982 it opposed a resolution requesting the Secretary General of the $\mathrm{UN}$ to initiate consultation with all parties concerned with a view to achieving a comprehensive settlement of the conflict, on the grounds that it effectively disputed Indonesian sovereignty over East Timor ${ }^{53}$.

Australia's voting in the UN took place in the context of an ambivalent relationship with Indonesia on the one hand, and concerns about Cold War politics on the other. While Canberra was

49 Cable from Mr Woolcott to the Australian Department of Foreign Affairs, August 17, 1975. Reprinted in Documents on Australian Foreign and Defence Policy 1968-1975, 1981:197

50 Senate Standing Committee on Foreign Affairs and Defence, 1983 The Human Rights and Conditions of the People of East Timor, Government Publishing Service, Canberra, p.72

51 ibid, p.75.

52 ibid, p.75.

53 Australian Department of Foreign Affairs Annual Report 1977, p.40; Annual Report 1978, p.29 Annual Report 1982, p.49. 
concerned that the Indonesian leadership still had expansionist ideas ${ }^{54}$, it was also concerned that an independent East Timor would pose a threat to the territorial integrity and political stability of Indonesia, and endanger regional stability. Good relations with Indonesia were also considered to be of prime importance 55 . Australia's position was also influenced by the posture adopted by the United States. Attempts to balance internal opposition to the Indonesian government with foreign policy concerns led to a somewhat ambivalent approach to the Timor conflict.

\section{Criticism of Australia's position}

Australia's Senate Standing Committee on Foreign Affairs and Defence has been critical of Australian policy regarding East Timor and of the extent to which the Department of Foreign Affairs has influenced that policy. The Committee noted that the Department had adopted "a less than even handed approach in discussing conditions in East Timor" and that the Department was uncritical in its assessment of Indonesian activity there 56 . The Committee did support the pragmatic approach taken by Canberra, agreeing that de facto recognition of Indonesian administration of East Timor was something Australia must accept. However the Committee drew the line at de jure recognition, arguing that such recognition discredits Australia in the field of human rights and in the United Nations. The Committee took the view that "the Indonesian occupation of East Timor is an illegal act which the mere passage of time cannot legitimise", and recommended that an internationally recognised act of self-determination be made the condition for formal recognition of Indonesian rule in East Timor 57 . To an extent, this word play over the distinction between de facto and de jure recognition amounted to tacit approval of Australia's bilateral relations with Indonesia; criticism by the Senate Standing Committee is thus somewhat hypocritical.

Australian policy regarding East Timor also attracted criticism from the opposition Labour Party, although the party's position altered significantly when it came to power. Following Prime Minister Fraser's acceptance of Indonesia's de facto control, Opposition leader Bill Hayden described Indonesia's occupation of East Timor as unjustifiable, illegal, immoral and inexcusable,

54 Harold Crouch, 1990 "Indonesia and the Security of Australia and Papua New Guinea" in Desmond Ball and Cathy Downes (eds), Security and Defence: Pacific and Global Perspectives [publisher], Sydney, NSW., p.379.

55 John Fuhrman, 1993 "East Timor: An Intractable Problem”, New Zealand International Review, Vol.18, No.1, p.26.

56 Senate Standing Committee on Foreign Affairs and Defence 1983, p.78.

57 ibid, p.78-80 
and recognition of it as inconceivable 58 . Following their victory in the 1983 Federal elections, the Labour Party under Bob Hawke began to take a more conciliatory approach to Indonesia and the East Timor issue. A resolution adopted by the Labour Party in 1982 calling for a reversal of the Liberal government's recognition of East Timor was overturned during the 1984 Federal Labour Party Conference. The Labour Party voted to officially recognise Indonesian incorporation of East Timor ${ }^{59}$. The 1982 Conference had confirmed the Labour Party's support for the "inalienable rights of the East Timorese to self-determination and independence" and rejected Australian Government recognition of annexation, but by 1986 all reference to self-determination, independence and human rights had been removed from the Party's platform60. The Liberal and Labour parties now concur on recognition of Indonesia's annexation of East Timor, arguing that whilst the circumstances of the annexation were regrettable, it is now a fait accompli and must be accepted as such. The Timor issue is still prominent in Australia's party politics, within parties if not between them 61 .

Fuhrman suggests that recognition of Indonesian annexation of East Timor is still a divisive issue within the Labour Party62. These divisions were aggravated by the restrained response of the Labour government to the 1991 Dili massacre, particularly in light of Hawke's tearful outburst decrying China's use of force in putting down the 1989 Tiananmen Square democracy protests. Although Prime Minister Hawke did not go so far as to renew the question of self-determination, he did call on the Indonesian government to abandon the use of military force and attempt to reach a negotiated settlement in East Timor63. More recently, the left wing of the Labour Party has described government policy toward East Timor as "bankrupt"64.

It appears that the Clinton administration's stance on East Timor has influenced Australia's position on human rights issues at least. In March, 1993, Australia followed the US lead and supported a resolution critical of Indonesia in the Uited Nations Commission on Human Rights. This position must have been uncomfortable however, because when Prime Minister Paul Keating visited Washington in September, 1993, he urged President Clinton to be more "balanced" in his

58 Cited in Gunn ,1994, p.143

59 Peter Hastings, 1984 "Two Weeks in Politics" Far Eastern Economic Review, July 12, p.13; Gunn 1994, p.146

60 Gunn, 1994, p.149.

61 Karen Middleton, 1995, "Left Slams Policy on East Timor", The Age, July 3.

62 Fuhrman, 1993, p.28.

63 ibid.

64 Middleton, 1995. 
approach to human rights in Indonesia. Jakarta received these remarks warmly and Foreign Minister Ali Alatas praised Keating's "moral fibre"65.

Australia's recognition of Indonesia's annexation, though consistent with its response to the Timor conflict generally, is inconsistent with past decisions to withhold recognition of governments who control territory or came to power as a result of force; it withheld recognition of the Vietnamesebacked regime in Cambodia, of the Soviet-backed government in Afghanistan, and of the Soviet annexation of the Baltic states. In this last instance, Australia withheld recognition for over 30 years, negating any suggestion that the duration of Indonesia's de facto control over East Timor can be accepted as de jure control66. Unlike other instances of Canberra withholding recognition, in this case "both governments [Australian and Indonesian] have sought to 'contain' differences over East Timor and not let it affect other aspects of their relationship"67. Suter points out that Australia has a vested interest in seeking to maintain stability in Indonesia 68 and, as discussed in Chapter 1, support for East Timor's independence would run counter to this aim.

\section{Sovereignty over Resources}

The 1958 Geneva Convention on the Continental Shelf recognises, in Article 2, the sovereign rights of a coastal state over its continental shelf for the purpose of exploring it and exploiting its natural resources. These rights are exclusive and do not depend upon any proclamation or occupation69. Indonesia's claim to the oil and gas reserves in the Timor Sea rests on the claim that Indonesia is the sovereign authority in East Timor. It has been demonstrated that this claim is flimsy at best.

The dubious legality of Indonesia's claim to East Timor, and of the Timor Gap Zone of Cooperation Treaty, has not deterred oil companies from commencing oil and gas exploration, however. By March, 1986, the Australian government had reportedly received A $\$ 31.5$ million from bids from oil companies wanting rights to drilling sites in the Timor Gap area 70 . There have been two commercial oil discoveries in the Zone of Cooperation since since the treaty came into

\footnotetext{
65 Herbert Feith, 1993, The East Timor Issue Since the Capture of Xanana Gusmao, East Timor Talks Campaign, Melbourne, p.8.

66 Stepan, 1992, p.924.

67 Australian Department of Foreign Affairs, 1979, Annual Report 1978, p.29.

68 Suter,1993, p.297-298

69 Rene-Jean Dupuy, 1974 The Law of the Sea, Current Problems, Oceania Publications Inc, Dobbs Ferry, New York, p. 137.

70 Sydney Morning Herald, March 4, cited in Taylor. 1991, p. 208.
} 
force in February, 1991. The largest, expected to yield an estimated 50 million barrels of oil, is operated by Australian-based mining giant The Broken Hill Pty Company. Nine other companies are exploring the area, at an estimated cost of $\mathrm{A} \$ 400$ million 71 .

Suter suggests that oil companies have no interest in which government controls access to oil resources, as they are able cooperate with any government, but they do require a degree of stability before making the considerable investment needed for exploration and exploitation 72 . Taylor disagrees. He notes that in December, 1974, a party of American officials travelled to Lisbon on behalf of the Oceanic Company of Denver, Colorado, to sign a Timor Gap exploration agreement with the Portuguese government. Adobe Oil and Gas, another American company, had already signed a similar agreement 73 . The potential of the Timor Gap not been widely realised at this time, and the concessions attracted little interest. Australian oil interests were an exception, however. Their explorations in areas adjacent to the Timor Gap had indicated that the sea-bed could contain substantial oil and gas deposits. Taylor argues the Australian oil lobby perceived that its interests would be best protected by Indonesian annexation of East Timor. The oil lobby pursued an intense campaign of backroom lobbying in favour of integration and later devoted considerable resources to reversing the Portuguese - American exploration agreements 74 .

Magalhaes also notes a convergence of the interests of the oil lobby and those of Australia and Indonesia in supporting Indonesian annexation of East Timor ${ }^{75}$. But this convergence of interests should be understood in terms of a perceived likelihood that an Australian-Indonesian agreement over the Timor Gap would be reached long before an independent East Timor emerged to dispense exploration contracts. East Timor's sovereign rights over its continental shelf are permanent ${ }^{76}$. If an independent East Timor was established, Indonesian control over the seabed, the resources therein, and East Timor's territorial waters, would cease in practice as they have no basis in law.

71 Reuter News Service, 1995, “Australia Welcomes World Court's Timor Decision”, June 30.

72 Suter, 1993, p.301.

73 Taylor, 1991, p. 37 - 38.

74 Commonwealth Parliamentary Debates, House of Representatives, Canberra, February 25, 1978; cited in Taylor, 1991, p. 38.

75 A. Barbedo de Magalhaes, 1992 East Timor: Indonesian Occupation and Genocide, Presidents Office, Oporto University, p.51.

76 In 1955, the Third Committee of the UN General Assembly adopted a draft article, as part of the Human Rights Covenants, on the right of self -determination. The second paragraph of the article provides: "The peoples may, for their own ends, freely dispose of their natural wealth and resources without prejudice to any obligations arising out of international economic cooperation, based upon the principle of mutual benefit, and international law. In no case may a people be deprived of its own means of subsistence. 


\section{The Australian High Court Challenge}

Australia's right to make a treaty with Indonesia concerning East Timor's resources came under attack domestically as well as in the International Court of Justice. Representatives of the Australian-based Timorese resistance organisation, the National Council of Maubere Resistance, challenged the validity of the 1990 Federal legislation implementing the Zone of Cooperation Treaty in Australia's High Court, arguing the treaty "is, and at all material times has been, void in accordance with international law"77. These allegations had much in common with those made by Portugal before the ICJ in that they focused on Australia's right to make the treaty. The case brought before the domestic court also cited Australia's domestic legislation and constitution, challenging the right of the executive to make tax payments to Indonesia (in accordance with the agreement to share profits from the different sections of the Timor Gap), and arguing the Commonwealth of Australia did not have the executive power to make the treaty 78 .

Although the Court upheld the legislation's validity, important legal and political issues were raised. The High Court was required by this case to delimit the extent of Australia's sovereign authority. The case questioned the point at which the Commonwealth ceases to be guided by its constitution and domestic law and instead becomes bound by international law. The High Court was required to determine the extent of the Commonwealth's external affairs power as allowed for in section 51(29) of the Australian Constitution79. Although Portugal's suit in the International Court of Justice named Australia as the defendant, the suit was as much directed at Indonesia as Australia, and this was Portugal's downfall. The High Court challenge was more clearly directed at Australia itself. The case was politically embarrassing for Australia and the government questioned the jurisdiction of the Court in this case. However, because the allegations are related to the constitution and tax laws, the High Court was the most appropriate forum for the case to be heard.

\section{The importance of defining East Timor's legal status}

The case brought before the ICJ by Portugal regarding the Timor Gap Zone of Cooperation Treaty was important not only in terms of the settlement of the Timor conflict but in terms of the legal principles it involved. It came at a time when renewed attention was being paid to international law, which is becoming sought after as a tool for clarifying relations among states since the

\footnotetext{
77 cited in Ian McPhedran, 1993 "Self-determination Basis of Court Move", The Canberra Times June 26, p. 15

78 Matebian News, November 1993, p.4

79 Verge Blunden, 1994, "Treaty With Indonesia Challenged", Sydney Morning Herald, August 10, p.8.
} 
dichotomy of the cold-war order has collapsed 80 . Law is increasingly being promoted as universal in nature and beyond nationalistic interpretation. Janis writes "nothing catalyzes the transformation of international law more substantially than the decline of the sovereign state" 81 though the challenge is not so much to the state itself as to the extent of its sovereignty - as could be seen in both the ICJ case and the case in Australia's High Court.

The case highlighted Australia's relationship with Indonesia and, like the case in Australia's High Court, questioned the extent to which states can promote bilateral relationships at the expense of international legal principles designed to regulate such relationships. As Lord McNair points out, states enter into agreements, such as the Declaration on Friendly Relations, by exercising their sovereignty, and they intend the effect of that act to be a limitation of their sovereignty 82 . Membership of the United Nations, and ratification of its resolutions, means acceptance of the body of customary international law. Such acceptance means no state is sufficiently independent or sovereign to use force, recognise advantage gained from the use of force, or in any other manner disregard international law.

In addition to clarifying the obligations of third parties involved in the East Timor conflict, the case before the ICJ effectively required the Court to clarify the current legal status of East Timor itself; whether the Decolonisation framework established by the United Nations still applies to East Timor or whether, as Australia argues, Indonesian rule must be accepted as a fait accompli. The value of this case would not have been found in the practical application of the Court's ruling, whatever it may have been, but in the clarification of international law as it affects the parties involved, especially East Timor. The elucidation of legal principles would have provided a firm basis for future efforts to win self-determination for East Timor. A ruling in Portugal's favour would have been unlikely to affect bilateral relations between Indonesia and states such as Australia and New Zealand however, both of which have chosen to reinterpret or ignore principles of their respective foreign policies in order to develop relations with Jakarta.

80 Mark W. Janis, 1991 "International Law?" Harvard International Law Journal, 32:2, p.364.

81 ibid, p.368.

82 McNair, 1961, p.754. 


\section{Chapter 4 \\ New Zealand and East Timor}

New Zealand's response to the East Timor issue is in many ways typical of the international community. New Zealand has consistently supported the political rights of the East Timorese to self-determination as well as their human rights. But, in common with other states, this support has been verbal rather than concrete. New Zealand maintains relations with Indonesia and is active in developing the relationship.

Several factors have influenced New Zealand's response to the Timor conflict. Relations with ASEAN and economic interests in Southeast Asia have been an important factor, as have security interests in the region. New Zealand is a small state with a characteristic interest in the rule of international law yet the legal principles raised by the conflict have not had a great impact on this country's response. Relations with Australia and the United States have been of prime importance; New Zealand is to a certain extent, constrained by their approaches to the conflict 1 .

\section{New Zealand in the wider world}

New Zealand's relations with the US have their origins in the Second World War. McMillan identifies the fall of Singapore to the Japanese in 1942 as the catalyst which led New Zealand to explore the possibility of a security relationship with the US. Realising that Britain did not have the capacity to protect New Zealand's security interests, New Zealand sent an envoy to Washington ${ }^{2}$. Like Australia, New Zealand became aware during the Second World War that the future security and development of the Pacific, important for its own security, could only be achieved with US cooperation.

Following World War II, New Zealand and Australia became responsible for managing the Pacific region in the interests of the Western alliance. US hegemony in the region meant little was required of New Zealand to maintain Pacific stability ${ }^{3}$. This changed somewhat in the 1980s as island states became more independent and outward looking in their foreign policy. Soviet interest

\footnotetext{
${ }^{1}$ However, Maurice East argues that in the post cold war era, small states have fewer constraints on their foreign policy as the dichotomy of the cold war collapses, and regional and multilateral issues become more important - Seminar: "The Foreign Policy of Small States", October 4, 1994, Institute for Strategic Studies, Wellington.

2 Stuart McMillan, 1987 Neither Confirm Nor Deny: The Nuclear Ships Dispute Between New Zealand and the United States, Allen \& Unwin/Port Nicholson Press, Wellington. p.6.

3 David Hegarty, 1991 “Australia, Indonesia and Stability in the South Pacific", in Desmond Ball and Helen Wilson (eds), Strange Neighbours: The Australia-Indonesia Relationship, Allen \& Unwin, Sydney, p.68.
} 
in the region increased in the early 1980s, expressed in fishing agreements with Kiribati and Vanuatu, and was finally articulated by Gorbachev in $1986^{4}$. Concern that an increased Soviet presence might extend superpower conflict into the area, and into the Asia-Pacific region as a whole, increased interest in the stability of anti-communist Indonesia, a powerful influence in the region.

\section{After the Cold War}

Young argues that during the Cold War, the US viewed the Asia-Pacific region solely in the context of superpower relations ${ }^{5}$. As the containment and denial strategy which was the basis of America's policy in Asia and the Pacific was relaxed, so pressure on allies like Australia and New Zealand to view conflict in the region in ideological terms decreased. Lehmann identifies a shift from the geopolitics of the Cold War to the geoeconomics of the post-Cold War as important to relations in the Asia Pacific region ${ }^{6}$. The realist perspective of the world as a dangerous place where security is defined as military security and politics as a power play has made room for economic considerations. Security has been redefined as secure access to markets and politics as a means of securing this. This is particularly true of the Indonesia - New Zealand relationship. The emphasis in policy making has shifted from strategic to economic concerns, and bilateral relations are less dominated by security agreements. New Zealand's relationship with Indonesia is characterised by economic rather than security concerns which contrasts with Australia's more ambivalent relationship with Indonesia.

Although trade is of increasing importance in regional relations, security issues are still a prominent feature of policy discussions ${ }^{7}$. New Zealand's special defence relationship with Australia, its involvement in the Five Power Defence Arrangement with Britain, Singapore, Malaysia and Australia, and in the ANZUS agreement, mean that New Zealand's security views are linked to those of its trans-Tasman neighbour. New Zealand participates in military exercises with Australia and Indonesia. However, without the pressure of having Indonesia as a neighbour, and

4 Jusuf Wanandi, 1991 "Developments and Challenges in the South Pacific" in Desmond Ball and Helen Wilson (eds), p.53.

5 Thomas-Durrell Young, 1994 "Prospects for Future Australian-United States Defence Cooperation", The Pacific Review, Vol.7, No.2, p.197.

6 Jean-Pierre Lehmann, 1994 "Reorganizing Western Cooperation: A Prescription for Collective Pax Americana", The Pacific Review, Vol. 7, No. 2. p.145.

7 Tony Kevin, 1991 "Major Power Influences on the Southeast Asian Region: An Australian View" in Ball \& Wilson (eds), p.11. 
being less firmly ensconced in the Western Alliance ${ }^{8}$, New Zealand could potentially pursue an independent policy on East Timor. New Zealand has not done this and instead consistently refuses to condemn Indonesian rule there and confines itself to commenting on human rights abuses and development issues. This can perhaps be attributed to the fact that despite a change in emphasis from geopolitics to geoeconomics as the basis of the regional policies of Australia, New Zealand and the United States, New Zealand's interests are seen as best served by a continuation of its early policy of supporting de facto Indonesian rule in East Timor. Although the justification for it has changed, the policy itself has not.

\section{New Zealand in the Asia-Pacific region}

Although a small state in global terms, in the Pacific New Zealand is a major actor and directly affected by conflict and instability in the region. Pacific politics have also contributed to the maintenance of New Zealand's East Timor policy. Concerns about stability were highlighted by the May 1987 coup in Fiji. In Papua New Guinea, the conflict in Bougainville, shifting coalition governments, law and order problems and restiveness in the army are identified as potentially destabilising factors 9 .

Against this background, political instability in Indonesia is even more unwelcome as it could become a catalyst for conflict in the South Pacific, particularly in Papua New Guinea where it shares a border. Political principles such as self-determination seem relatively unimportant against the perceived threats to security which might come from upholding them. Regional security issues have replaced Cold War alliances as a major influence on New Zealand's policy toward East Timor, but the policy itself has remained largely unchanged. Hegarty suggests Indonesia has attempted to gain support for its East Timor position through closer relations with South Pacific nations and has expanded diplomatic links in an effort to gauge pan-Melanesian support for the Organisasi Papua Merdeka resistance movement in West Papua ${ }^{10}$.

Wanandi suggests that ASEAN nations will increasingly become involved in development in South Pacific nations, previously the preserve of Australia and New Zealand, in order to reduce their economic vulnerability ${ }^{11}$. As a member of the South Pacific Forum, and a primary source of

8 The breakdown of the ANZUS alliance following the introduction of New Zealand's nuclear ships policy is an example of this. Also, unlike Australia, New Zealand does not have US defence research and communications facilities such as those at Pine Gap and Nurrangar on its territory - Young, 1994, p.198.

9 Hegarty 1991, p.75.

10 ibid, p.73.

11 Wanandi, 1991. 
development assistance for many Pacific island states, New Zealand will be closely involved in any such developments. Echoing New Zealand's Foreign Ministry, Australia's Foreign Minister, Senator Gareth Evans, identified economic development as the key to political stability in the region and argued the development of democratic political processes should be encouraged ${ }^{12}$.

\section{Formulating New Zealand's East Timor Policy}

New Zealand's official response to the conflict in East Timor has been remarkably consistent. Successive governments have considered the stability of the region, and Indonesia in particular, as their primary concern. While New Zealand insists it has never condoned the 1975 invasion, it regards Indonesia as having de facto control of the former Portuguese colony. New Zealand has not been able to avoid addressing the Timor question altogether, however, particularly following the death of a New Zealand citizen in the 1991 Dili Massacre, the reporting and filming of which raised the conflict's profile in world-wide. New Zealand can hardly be characterised as an outspoken critic of the Indonesian regime however; the policy stance of successive governments suggests good relations with Indonesia have consistently had most priority.

The bilateral framework in which New Zealand first developed its East Timor policy was constructed from ideological and Cold War concerns. Kerr suggests that at the time of the invasion, 'security' was a broad concept, incorporating economic development, state and nation building, and regime maintenance ${ }^{13}$. In addition to these aspects, New Zealand identified stability, especially in the extensive, fragile state of Indonesia, as the key to regional security.

When Indonesia invaded East Timor, "regional stability and security"14 were thus stressed by New Zealand as being of primary importance. New Zealand noted that Indonesia was troubled by separatist movements in other parts of its archipelago, and that an independent East Timor could aggravate this threat to stability by providing a base for those seeking a disintegration of Indonesia, or for dissidents such as the PKI who could operate with impunity from an independent Timor ${ }^{15}$. This was similar to Indonesia's view of where an independent East Timor might lead, suggesting that information received by the Ministry came from the Indonesians themselves, or from other sources supporting such views.

12 Gareth Evans, 1988, cited in Hegarty 1991, p.69.

13 Pauline Kerr, 1994 "The Security Dialogue in the Asia-Pacific", The Pacific Review, 7:4, p.397.

14 Briefing for a visit of the Minister of Foreign Affairs to Southeast Asia, 16 March - 8 April, 1976, dated February 12, 1976; document released under the Official Information Act.

15 ibid. 
By the time the Cold War order collapsed, diminishing the ideological and balance-of-power concerns that had influenced New Zealand's policy of support for the Indonesian regime, the relevant relationship had developed to the extent that the Ministry of Foreign Affairs considered it "too important for it to be dominated by [the East Timor] issue"16. Consequently, New Zealand's East Timor policy did not alter in any fundamental way. "Stability" gained less mention in government communiques as the reason for supporting Indonesian rule in East Timor, but remained a concern for the New Zealand government.

The government characterised its response to the invasion as "restrained", particularly in its criticism of Indonesia ${ }^{17}$. Annexation of East Timor was quickly accepted as a fait accompli, and whilst New Zealand has since raised human rights concerns with Jakarta, successive governments have avoided commenting on political questions, being careful to distance human rights issues from other aspects of the bilateral relationship.

Events in East Timor were said to have "cast a shadow over our attitude toward Indonesia"18, but officials noted that despite having the lowest per capita GDP of the ASEAN countries, Indonesia's total GDP is equal to $40 \%$ of the combined GDP of all other ASEAN countries, making it a leading economic and political power in the region ${ }^{19}$. Trade between the two countries has grown apace; the value of New Zealand exports to Indonesia increased from NZ\$99 million in 1986 to NZ\$173 million in 1991. The volume of trade that year was NZ\$239 million ${ }^{20}$.

New Zealand allocates some bilateral development assistance to Asia of which NZ\$5 million goes to Indonesia ${ }^{21}$. Following the invasion of East Timor, the percentage of New Zealand aid spent in Indonesia increased from $31 \%$ in $1975-6$ to $43 \%$ in $1976-77^{22}$. Following a visit to East Timor in

16 Perspectives on New Zealand's Foreign Policy, Ministry of Foreign Affairs Information Bulletin No. 19 , November, 1986, p.38.

17 Report of a call from the New Zealand Ambassador in Jakarta to the Minister of Foreign Affairs, May 5, 1976; document released under the Official Information Act.

18 ibid.

19 ibid.

20 Asean and New Zealand, Ministry of Foreign Affairs Information Bulletin No. 40, September, 1992, p.6.

21 Sarah Crichton, 1994 "Push for East Timor Aid Likely - MP", The Dominion, November 2, p.15.

22 Briefing prepared prior to visit by the new Indonesian Ambassador, October 18, 1976; document released under the Official Information Act. 
October, 1994, MP Roger McClay, leader of a parliamentary delegation, suggested a portion of New Zealand's aid to Indonesia be ear-marked for East Timor to improve its infrastructure 23 .

New Zealand also maintains a defence cooperation programme with Indonesia. Infantry officers, small arms and combat instructors, marine patrol pilots, Skyhawk technicians and flying instructors have all received New Zealand training ${ }^{24}$. These military links have become increasingly contentious as concern about human rights violations by the Indonesian military intensifies. The Bolger government has rejected calls from its Labour and Alliance opponents to curtail military links in protest at such abuses.

\section{Other states and New Zealand}

New Zealand's stance is hardly unique. Like Australia and some other states, New Zealand has weighed the advantages possibly gained from standing by self-determination principles and supporting independence for East Timor in the United Nations, via pressure on Indonesia, as against the considerable benefits derived from maintaining good relations with Jakarta.

Nevertheless New Zealand was reluctant to get itself identified as an outright supporter of Indonesia. In June, 1976, Secretary of Foreign Affairs Frank Corner advised the Minister that "it is doubtful, however, whether any New Zealand interest would benefit tangibly by identifying New Zealand too closely with the [blacked out] way the Indonesians are setting about achieving their objective" 25 . New Zealand was anxious not to attend the Provisional Goverenment of East Timor (PGET) referendum calling for integration unless representatives from other states also attended. Foreign Affairs Minister Brian Talboys was informed by the Ministry in 1978 that Indonesia's de facto control of East Timor had been accepted by several other states including five ASEAN nations and Australia 26.

Compared with Australia, New Zealand's response has remained deliberately muted, possibly more consistent. Its relations with Indonesia are less intimate (and therefore less turbulent) than Australia's; New Zealand has never entered into a treaty relationship with Indonesia concerning

23 Crichton, 1994; Catrionna MacLennan, 1994 "NZ's Diplomacy over East Timor Defended", The Dominion, November 17, p.2.

24 Tim Howard 1994, East Timor: New Zealand's Waterloo?, Background Paper 11/19, Foundation for Peace Studies Aotearoa/New Zealand.

25 Recommendations from Frank Corner, Secretary of Foreign Affairs, to the Minister, June 21, 1976; document released under the Official Information Act.

26 Memorandum for Cabinet from the Office of the Minister of Foreign Affairs, February 8, 1975; document released under the Official Information Act. 
East Timor, and has not seen it necessary to extend de jure recognition to Indonesian annexation of East Timor. When, on the 40th anniversary of Indonesia's independence, Australian Prime Minister Bob Hawke announced publicly that Australia recognised Indonesian sovereignty in East Timor, New Zealand chose not to follow suit. The Ministry of Foreign Affairs stated that while it was prepared to accept de facto Indonesian control, it was "unwilling to be as forthcoming" as Australia over the sovereignty issue, especially while the United Nations remained involved 27.

\section{Hoping for "a logical solution"}

The New Zealand government had not publicly expressed any view on the decolonisation of East Timor when, in February 1975, newspaper reports first suggested that Indonesia was preparing to invade $^{28}$. The Ministry of Foreign Affairs advised Acting Prime Minister Hugh Watt that if questioned by the press he should point out that New Zealand believed the right of the Timorese to self-determination was fundamental and that while several options for the future of Portuguese Timor were available, New Zealand would welcome integration with Indonesia as "a logical solution", providing of course this was a decision made by the Timorese themselves 29 .

\section{Sympathy for Indonesia's situation}

Prime Minister Bill Rowling was informed in August, 1975, of the increasing likelihood that Indonesia would ignore international criticism and intervene militarily in East Timor ${ }^{30}$. Whilst officials considered Indonesia's concern about having instability on its borders understandable (a view shared by Australian Prime Minister Gough Whitlam ${ }^{31}$ ), it recommended that, in the event of an invasion, the Prime Minister reiterate New Zealand's long-standing support for the principle of self-determination. In the event however, concern for stability outweighed such support.

The desire to balance its reputation with its interests led New Zealand to be very specific about the language it used when referring to events in East Timor. When the invasion eventuated in

27 Briefing for a meeting between the Deputy Prime Minister and Indonesian Foreign Affairs Minister, September 1985; document released under the Official Information Act.

28 Phil Goff, 1978 "The Australian and New Zealand Response to the East Timor Controversy", paper presented to the Political Science department, Auckland University; unpublished.

29 Message from Secretary of Foreign Affairs, Frank Corner, to the Acting Prime Minister, 26 February, 1975; document released under the Official Information Act.

30 Reports from the Secretary of Foreign Affairs to the Prime Minister, dated 18 August, 1975, 22 August, 1975, and August 27, 1975; released under the Official Information Act.

31 Report from the Secretary of Foreign Affairs to the Prime Minister, August 27, 1975; released under the Official Information Act. 
December 1975, New Zealand was reluctant to acknowledge it as such. The Ministry of Foreign Affairs avoided the word "invasion" and described Indonesia's action as "intervention in support of the integrationists". Officials reported to the Minister that the position in East Timor was that "the integrationists, with Indonesian military support, control the capital, Dili, and have the upper hand in the rest of Portuguese Timor"32. The word "invasion" did not replace the preferred phrase "military intervention" until April, $1977^{33}$.

Following the invasion, New Zealand continued to indicate its support for the principle of selfdetermination, but did not challenge Indonesia's annexation of East Timor. Rather than calling for an immediate withdrawal of Indonesian troops, New Zealand argued the need to restore stability so that the people of East Timor could exercise their right to self-determination "free from threats or fear of force or violence" 34 and that peace and stability were most likely to be assured by integration 35 .

New Zealand took the position that whilst it could not condone Indonesia's armed intervention and "regretted" the action ${ }^{36}$, it hoped Indonesia would be fair in implementing an act of selfdetermination under the auspices of the United Nations. Although New Zealand asserted that Indonesia had not, by virtue of its intervention, assumed the status of 'administering power' over East Timor, this position implied that New Zealand considered Indonesia as having sufficient authority and presence in East Timor to implement an act of self-determination.

\section{Limited information}

At the request of Roskill MP Phil Goff, documents relating to East Timor were released in 1994 by the Ministry of Foreign Affairs under the Official Information Act. These give the impression that little "intelligence" was being received from sources such as the United States and Australia, although both states are known to have been closely monitoring developments (Australia had a consulate office in Dili). Indeed, US President Gerald Ford and Secretary of State Henry Kissinger had left Jakarta only hours before the invasion commenced.

32 Report to the Minister from the Secretary of Foreign Affairs, December 23, 1975, paragraphs 3 and 5 respectively; document released under the Official Information Act.

33 "Timor: Disposal of New Zealand Relief Funds", April 29, 1977; document released under the Official Information Act.

34 ibid

35 Briefing, October 18, 1976

36 Former Prime Minister, Bill Rowling, cited by the Ministry of Foreign Affairs, December 23, 1975; document released under the Official Information Act. 
Much of New Zealand's understanding of the situation in East Timor prior to the invasion came from a visit by staff of the New Zealand Embassy in Jakarta during July, 1975. New Zealand does not seem to have much concerned itself with the underdeveloped Portuguese colony until trouble erupted, raising the spectre of a disintegrating Indonesia. It is perhaps understandable that the Ministry of Foreign Affairs should concur with Indonesia's view, given the political climate at the time the invasion took place and New Zealand's desire to see East Timor integrated without delay.

Alternative scenarios had been proposed, however. Writing prior to the invasion, Hoadley suggested that Indonesia's fears were largely groundless. He noted that both Russia and China (supposed supporters and sponsors of a 'Cuba of the South') had recently attempted to improve relations with Indonesia ${ }^{37}$ and refuted suggestions that East Timor would become a base for Indonesian dissidents and a source of subversion; the PKI were seen as lacking support, and FRETILIN had taken care to distance itself from radical ideology and its radical Mozambican cousin FRELIMO. If anything, FRETILIN promoted itself as a democratic socialist party. During a visit to Australia in December, 1974, its representative, Jose Ramos Horta, identified his party's ideology with that of Australia's Labour Party ${ }^{38}$.

Hoadley's arguments did not influence the New Zealand position and sympathy for the plight of what is seen to be a fragile state has remained a feature of the official response to the invasion and subsequent annexation of East Timor. A letter from New Zealand's Minister of Foreign Affairs to his Indonesian counterpart, Adam Malik, dated July 8, 1976, assured him that New Zealand "fully understands" the reasons for Indonesia's concern to resolve the Timor issue ${ }^{39}$. Eighteen years later, in May, 1994, Prime Minister Jim Bolger reaffirmed New Zealand support for Indonesia's control of East Timor when visiting Jakarta ${ }^{40}$. This suggests that public pressure and reports of gross human rights violations which emerged in the interim has had scant effect on New Zealand's East Timor policy.

\section{Accepting integration}

Once Indonesian control was accepted as de facto, the legal status of East Timor declined as an issue of concern in New Zealand policy, except that it remained unresolved in the United Nations.

37 J. Stephen Hoadley, 1975b The Future of Portuguese Timor Occasional Paper \#27, Institute of Southeast Asian Studies, Singapore, p.24.

38 Hoadley, 1975b, p.25.

39 Document released under the Official Information Act.

40 NZPA 1994 "Stud Bulls Take Bolger's Mind Off Human Rights" Christchurch Press, May 18, p.3. 
New Zealand's sympathy with Indonesia, and desire to maintain good relations led it to condone the 1976 'referendum' calling for integration held by the Indonesian-backed PGET. Although ostensibly concerned that no internationally recognised act of self-determination had taken place, the New Zealand government accepted Indonesia's assurances that integration did indeed represent the will of the majority of East Timorese ${ }^{41}$.

A New Zealand diplomat from the Embassy in Jakarta joined representatives from Iran, India, Saudi Arabia, Nigeria, Malaysia and Thailand in Dili to witness the passage of a resolution seeking integration by the PGET, the result of the 'referendum' which New Zealand's representative, Alison Stokes, found procedurally suspect. Stokes was in Dili for less than two hours and her report described the event as being highly stage managed. Prior to arrival in Dili, Stokes reported, observers were given a pamphlet produced by the PGET which claimed "the East Timor people are fully behind the provisional government in the preparation for full integration into the Republic of Indonesia", a rather rash presumption given that the delegates, supposedly representatives of "the East Timor people" had yet to make their preference known ${ }^{42}$. She noted the actual vote was taken in secrecy, that there was no way of knowing who the delegates were or how they'd been selected, and that no option for the future political status of East Timor was discussed, other than integration.

Stokes' observations about the highly restricted nature of her visit were echoed in March the following year by American Congresswoman, Helen Meyner. A member of a delegation from the US House Committee on International Relations, Meyner explained that the delegation was required to go where it was taken, and at no time were any of the members allowed to converse privately with the East Timorese ${ }^{43}$.

In spite of reservations about the manner in which the resolution was passed, Stokes recommended that New Zealand encourage Indonesia to make the 'referendum' appear legitimate by attempting to get UN support for the result. New Zealand's official position, as of July 21, 1976, was that although it regretted the lack of UN involvement, it had "no evidence to show that integration with Indonesia is not the result desired by the majority of Timorese people". FRETILIN claims to the contrary were discredited by New Zealand which described the group as having "all the marks of

41 Report to the Minister following the Act of Integration, dated 21 July, 1976; document released under the Official Information Act.

42 Report made by NZ observer Alison Stokes following the Peoples Representative Council Meeting in Dili, June 1, 1976; document released under the Official Information Act.

43 Scott Sidell, 1981 “The United States and Genocide in East Timor", Journal of Contemporary Asia, Vol.11, No.1, p.50. 
a hard core communist guerrilla organisation" 44 . New Zealand stated it would continue to deal with the de facto government of East Timor, formerly the PGET but now considered effectively Jakarta.

Seeing the referendum as genuine was an expedient conclusion for New Zealand to reach given the doubts expressed by Stokes, who witnessed the act, and given Indonesia's continued engagement with FRETILIN guerrillas. To take Taber's assertion that guerilla war is an extension of politics by means of armed conflict ${ }^{45}$, the very existence of FRETILIN testifed to the political protest against an act of integration with Indonesia. A sufficient minority of the population thus cast doubt on New Zealand's argument that it had "no evidence" that integration was not the result desired by a majority of the Timorese.

\section{New Zealand at the United Nations}

New Zealand has never voted to condemn the invasion in the United Nations and in fact supported Indonesia by rejecting resolutions which condemned its actions. In 1978, New Zealand's Minister of Foreign Affairs, explaining New Zealand's vote in the United Nations, echoed Australian Ambassador Richard Woolcott 46 , saying:

[New Zealand has] made it clear we do not regard this use of force as a satisfactory way of solving international disputes. But you have to be realistic. No useful purpose is served by denying this fact of integration. 47

New Zealand abstained on the Resolution, passed by a majority in the United Nations General Assembly on December 10, which deplored the military intervention of Indonesian armed forces in Portuguese Timor and called upon Indonesia to withdraw. New Zealand objected to preambular paragraph 5 of the Resolution which reads:

Mindful that all states should, in conformity with Article 2, paragraph 4 of the Charter, refrain in their international relations from the threat or use of force against the territorial integrity or national independence of any state...

\footnotetext{
44 Report on a visit by the NZ Ambassador to Indonesia, Roger Peren, on a visit to East Timor, 5-9 January 1978, dated January 13, 1978; document released under the Official Information Act.

45 Taber 1969, p.26.

46 Quoted in "Timor Gap" chapter.

47 Report prepared for the Minister of Foreign Affairs, May 13, 1991; document released under the
} Official Information Act. 
New Zealand objected that this paragraph accorded East Timor a status which it did not have $\mathrm{e}^{48}$, although it can be understood to refer to Portugal, who, as administering power, could claim that a part of $i t s$ territory and independence had been violated.

Following a general election on November 29, 1975, only a week before the invasion of East Timor, New Zealand had had a change of government. Whilst the previous Labour government had announced it was determined to base its foreign policy on firm moral principles, the incoming National government questioned the very idea of a "moral" foreign policy 49 . The alleged tendency of small states to support moral causes and the rule of international law in international fora appears to have influenced New Zealand's initial response to the East Timor conflict prior to the invasion ${ }^{50}$, particularly as it was a Labour government which had espoused New Zealand's support for self-determination, but the pragmatic approach of the National government certainly influenced the effort to redefine the conflict as a legitimate act of intervention, removing any intimation of a violation of international law. McCraw notes that New Zealand's security and economic prosperity have been the main foreign affairs interests of the National party 51 .

Secretary of Foreign Affairs Frank Corner considered the wording of the Resolution to be an uneasy compromise "between those who understand Indonesia's motives and those who wish to support FRETILIN, come what may"52. Being very critical of FRETILIN's aims and supportive of Indonesia, New Zealand rejected the resolution. That New Zealand should support Indonesia's position in East Timor is not surprising in view of its sympathy and desire to maintain good relations with the government of South-East Asia's most populous country. It is also unsurprising that New Zealand rejected the wording of the UN resolution calling for a withdrawal of Indonesian troops given its reluctance to recognise that it was an invasion which had established them there; and in view of New Zealand's close relations with Australia and the United States.

With hindsight, it seems inconceivable that the government should have expected Indonesian rule to free the East Timorese from threats or fear of force or violence. At the time however, New Zealand appears to have accepted Indonesian assurances that it "will facilitate and not hinder the free expression of the will of the people of East Timor about their own future, in an atmosphere of

48 Report to the Prime Minister from Frank Corner, Secretary of Foreign Affairs, December 10, 1975; document released under the Official Information Act

49 David J. McCraw, 1994, “New Zealand's Foreign Policy Under National and Labour Governments: Variations on the Small State Theme?", Pacific Affairs, Vol. 67, No. 1, p.21.

50 ibid.

51 ibid.

52 Report to the Prime Minister from Frank Corner, Secretary of Foreign Affairs, December 10, 1975 
normality, order and peace" 53 in the hope that both its desire to see integration with Indonesia, and its paradoxical desire for a legitimate act of self-determination to occur would be satisfied.

Similar, though more softly worded resolutions were passed in the UNGA in each of the following seven years but support dropped from 72 votes for, 10 votes against, and 43 abstentions in 1975, to only 50 votes for, 46 votes against and 50 abstensions in 1982 . The following year the General Assembly deferred the debate and no resolution calling for Indonesian withdrawal has since been put before the $\mathrm{UNGA}^{54}$.

\section{Condemnation of FRETILIN}

New Zealand joined those opposing the UN resolution in 1979 after adopting the position that integration was "irreversible" and supported deferment of the resolution in 1983, arguing that moves in the UN to condemn Indonesia and encourage withdrawal only spurred FRETILIN on to greater efforts in their struggle. New Zealand is supported in this view by the Asiaweek which argued that the refusal of the UN to accept Indonesia's annexation merely keeps alive "a lost dream of left-leaning independence" 55 .

New Zealand considers FRETILIN's actions to be "both futile...and damaging in their effects on the daily life of the Timorese"56, because FRETILIN action draws retaliatory attacks from Indonesian armed forces which impacts greatly on the lives of civilians. The Ministry blames FRETILIN's actions for delaying the restoration of some measure of civil rights to the East Timorese and impeding work being done to improve their living conditions ${ }^{57}$.

Reports that FRETILIN guerrillas terrorise the population in areas where they operate have emerged constantly during the years since Indonesia invaded, but these are frequently discredited as Indonesian propaganda by human rights groups and church sources. After six civilians were killed on January 12, 1995, near Dili for example, Indonesia's Human Rights Commission found Army

53 ibid

54 David Robie, 1989 Blood on Their Banner: Nationalist Struggles in the South Pacific, Pluto Press, Leichhardt, NSW; p.57.

55 International Affairs editorial, "Facing Facts", Asiaweek, March 23, 1994, p.27.

56 Report for the Minister of Foreign Affairs from the Ministry, dated 7 September, 1984; document released under the Official Information Act.

57 Background report on NZ's position in the UN prepared for the Deputy Minister of Foreign Affairs, November 9, 1984; document released under the Official Information Act. 
reports that the six were guerrillas killed in a battle were false. It concluded that the men had been tortured and killed by Indonesian soldiers 58 .

Opposition groups in Indonesia are not above blame however. Amnesty International, a human rights monitoring organisation, has documented several cases of human rights abuse by opposition groups, including FRETILIN who admitted having killed those suspected of collaborating with Indonesia ${ }^{59}$. Nevertheless, it is misguided for New Zealand to condemn FRETILIN for delaying restoration of civil and political rights when, throughout Indonesia, the systematic curtailment of civil rights is well-documented with state terror used as a means of containing dissent.

\section{An ineffective approach}

A July 1984 briefing prepared for incoming Prime Minister David Lange by the Ministry of Foreign Affairs noted that there was "little evidence to suggest that representations by Indonesia's friends help improve the human rights situation in East Timor"60. This negates arguments put forward by both New Zealand and Australia that the best means of improving the lot of the East Timorese is through contact with Indonesia. Australian Foreign Minister Gareth Evans stated:

Australia's recognition of Indonesia's acquisition of East Timor has enabled Australia to pursue its concerns for human rights and economic development of the people of East Timor.61

New Zealand describes its approach as "quiet diplomacy"62, arguing that New Zealand can best help the East Timorese by maintaining ties with Indonesia, offering advice and humanitarian assistance where possible. New Zealand places strong emphasis on the belief that behind-thescenes persuasion is likely to have more effect that confrontational tactics. Whether such persuasion is actually attempted by New Zealand's representatives often cannot be proved, though it would seem that New Zealand is more likely to do so when the government is under domestic pressure to act.

58 Catrionna MacLennan, 1995 "Horror Stories Keep Coming In East Timor", The Dominion, March 8, p. 8 .

59 Power and Impunity: Human Rights Under the New Order, Amnesty International, 1994, p.34.

60 op cit

61 cited in Matebian News, June 93, p.2.

62 Suzanne Blumhardt, Southeast Asia division director, Ministry of Foreign Affairs, cited in Catrionna MacLennan, 1994, "NZ's diplomacy over East Timor defended" The Dominion, November 17, p.2. 
New Zealand's argument for maintaining relations with Indonesia is similar to that advanced by Australia for its continued relations with Indonesia, but is an argument that has been rejected by Timorese resistance organisations who point out that such relations did not prevent the Dili Massacre, November 12, $1991^{63}$. Alliance foreign affairs spokesperson, Keith Locke, has also rejected such claims, saying that rather than enabling New Zealand to influence Indonesian officials on human rights, our close bilateral relations mean the reverse is true ${ }^{64}$.

\section{Continuity through changes of government}

It was a Labour government which first articulated New Zealand's support for self-determination prior to the invasion. By the time Indonesian troops landed in Dili, New Zealand was governed by the National Party under Robert Muldoon. New Zealand foreign policy ceased to be guided by the antimilitarism and antiimperialism which was characteristic of the Labour party ${ }^{65}$. New Zealand's quick acceptance of the of East Timor integration as de facto cannot be attributed solely to a change of government, however. When Labour again came to power in 1984, it continued the policy of de facto recognition, despite previous Labour Party resolutions recognising the right of the Timorese to independence and citing FRETILIN as the legitimate representative of the Timorese people 66 . Prime Minister David Lange said in a December 1984 radio interview that the annexation of East Timor was irreversible and that to suggest an alternative government was unrealistic $^{67}$. He echoed Australian Prime Minister Bill Hayden who had earlier said that FRETILIN was declining in influence and losing support from the Timorese ${ }^{68}$.

The Prime Minister's stance was based on information provided by the Ministry of Foreign Affairs in July, 1984, that the integration of East Timor into Indonesia is not only "irreversible" but "incontrovertible"69. Mr Lange was informed that New Zealand had occasionally taken the opportunity to express muted reservations about the means of incorporation but had attempted to maintain good relations with Indonesia. Mr Lange was also informed that "policies adopted toward

63 Matebian News, 3:1, June, 1993, p.2.

64 cited by Catrionna MacLennan, 1995 "Two sides to East Timor story, says McKinnon", The Dominion, March 22, p.2.

65 W. David McIntyre, 1985 “Labour Experience in Foreign Policy”, in Hyam Gold (ed) New Directions in New Zealand Foreign Policy, Benton Ross, Auckland, p.11.

66 Robie, 1989, p.56.

67 ibid.

68 Sydney Morning Herald, September 10, 1984; cited in Robie, 1989, p.56.

69 Preliminary briefing paper prepared for Mr Lange, July, 1984; document released under the Official Information Act. 
East Timor are regarded by the Indonesians as the touchstone of a country's relationship with Jakarta"70. Relations with Jakarta being considered of great importance, the policy advice from the Ministry was accepted without reference to the Labour party's position on East Timor. The New Zealand position has been unaffected by subsequent changes of government.

\section{The 1994 New Zealand Parliamentary Delegation}

Recently, however, Ministry of Foreign Affairs influence on government policy on East Timor has been challenged from within Parliament. Labour MP Phil Goff initiated a petition in April, 1994, deploring the deaths of Timorese at the hands of the Indonesian military and calling on Indonesia to grant the Timorese their right to self-determination. Phil Goff, and co-sponsor, MP Nick Smith, said they wanted to ensure that the Prime Minister was receiving an alternate view point to the official Foreign Affairs advice that the annexation of East Timor was irreversible ${ }^{71}$.

Fifty-one Members of Parliament, a majority of the House, and representatives from all four parliamentary parties represented, signed the petition. It was presented to the Indonesian Charge d'Affaires in Wellington on May 5th, 1994. A joint statement issued by the six MPs ${ }^{*}$ who undertook to circulate the petition stated:

New Zealand cannot honestly express outrage about events in Bosnia...if we continue to remain silent about blatant violations of human rights that are occurring in our own back yard. Indonesia must be held to account internationally for its ruthless subjugation of East Timor people [sic].72

The petition echoes the UN Resolutions which New Zealand either abstained on, or opposed, in calling for the withdrawal of Indonesian troops from East Timor and the granting to the people of East Timor a right to self-determination. Jakarta reacted strongly to the petition. Indonesian Foreign Minister Ali Alatas said the MPs who signed the petition were "reflecting the voice of the minority group which receives false reports about the 27 th province of Indonesia"73.

70 ibid.

71 "MPs Urge Prime Minister to Raise Problem of East Timor During Indonesian Visit", joint Press Release from Phil Goff and Nick Smith, May 6, 1994.

* Phil Goff, MP for Roskill; Richard Northey, MP for Onehunga; Dianne Yates, MP for Hamilton East; Nick Smith, MP for Tasman; John Robertson, MP for Papakura; and Christine Fletcher, MP for Eden.

72 "MPs Unite to Condemn Indonesian Human Rights Violations in East Timor", Press Release from MP Phil Goff, April 15, 1994.

73 "Human Rights Row" The Dominion, May 7, 1994, p.3. 
The petition prompted the Indonesian government to issue an invitation to MPs to visit East Timor, and inform themselves first hand, of conditions there. After much debate about the value of such a visit, whether or not MPs would be able to meet with Timorese without inviting reprisals against them, and who should pay for the visit, a delegation visited at the end of October, 1994. The delegation reached something of a consensus in supporting continued New Zealand ties with Jakarta in order to influence Indonesian policy concerning East Timor. Leader of the delegation, Roger McClay, was quoted as saying:

I really feel very strongly that we need to continue to be a nation friendly with Indonesia so we can continue to bring about influence and suggest other ways in which things might be done. 74

After his return from East Timor, delegation member Phil Goff stated that "what is absolutely clear is that integration is not working"75. He noted that growing tensions between the East Timorese and Indonesian transmigrants and military personnel are bound to unleash further public protest against integration. In turn this would provoke a harsh reaction from the government and further repression, and suggested that the escape from this cycle of resistance and repression lay in an inter-regnum of benevolent rule by Jakarta. He argued that this was Jakarta's best option for ensuring a favourable vote in the act of self-determination which, he believes, must still occur ${ }^{76}$.

The action taken by Goff and his colleagues suggests that lobbying of parties and pressure on government from the public is effective to a limited extent. Under the mixed member proportional electoral system recently introduced in new Zealand, it is possible that such challenges to Ministry of Foreign Affairs policy recommendations will increase as the number of parties represented in parliament increases. However, given the importance placed on good relations with Jakarta by governments in the past, then regardless of party policy, it seems unlikely that such actions will alter government policy any more substantially than those of Phil Goff.

74 Sarah Crichton, 1994 "Push for East Timor Aid Likely - MP", The Dominion, November 2, p.15.

75 Phil Goff, 1994 "Benevolent Rule the Answer", The Dominion, November 15, p.5.

76 ibid 


\section{Human rights and New Zealand's response: redirecting public attention}

Once Indonesia's presence in East Timor was accepted as "irreversible", human rights and "the lot of the Timorese" 77 became the primary focus of the New Zealand government's policy regarding East Timor. Other issues of concern were the withholding of recognition by the UN and the state of Australian-Indonesian relations.

Although the government has been criticised for its response to human rights violations in Indonesia ${ }^{78}$, concern has been expressed (albeit, in the case of the MP's petition and the GovernorGeneral's comments, only vicariously). However unsatisfactory New Zealand's response, by engaging in the debate over how it should respond the government indicates it is aware of the issues involved. The debate itself, reported in the media, is sufficient to mollify public demand for official action.

The debate, at times heated, over how to best respond to human rights abuses obscures the more crucial issue of sovereignty for East Timor. To a certain extent this can be attributed to the emotive nature of the human rights issue. Evidence of human rights violations is tangible; spoken and written testimony, photographs and especially video footage incite public outrage and sympathy. In comparison, sovereignty is an abstract issue, ill-defined and only occasionally debated in popular forums ${ }^{79}$. Nevertheless, that sovereignty does not excite public interest to the same extent as human rights violations does not alter the obligation of governments to abide by international legal conventions, particularly those they had consented to abide by.

\section{Re-inventing official policy on East Timor}

The Ministry of Foreign Affairs declared in May 1983 that East Timor "is likely to be of decreasing political interest to us and internationally" 80 . Shortly afterwards, the Ministry noted an increase in public queries on East Timor. The government was faced with the problem of how to reconcile its opposition to the means of incorporation with its desire to maintain good relations with Indonesia and to respond to public outrage at reports of human rights abuses.

77 Report to the Ministry of Foreign Affairs from the New Zealand Embassy in Jakarta, September 7, 1984; document released under the Official Information Act.

78 See, for example, "Opposition slams view of East Timor" The Dominion, March 17, p.2.

79 An exception to this is Maori demand for tino rangatiratanga, which has made sovereignty an issue of public interest.

80 Report from NZ Ambassador to Indonesia, M. J. Powles, to Minister of Foreign Affairs Warren Cooper on a visit to Indonesia's Eastern provinces, dated May 20, 1983; document released under the Official Information Act. 
New Zealand, like Australia and other states, has accomplished this by emphasising its respect for human rights and condemning violations of them, whilst avoiding public comment and debate on the means of incorporation, i.e., the violation of East Timor's territorial integrity and right of the people to self-determination. Accepting Indonesia's de facto control has prevented any upset in relations with Indonesia, many of the human rights violations have been attributed to rogue elements in the military, to resistance fighters, or to provocation, as in the case of the 1992 Dili Massacre $^{81}$.

Human rights are mentioned for the first time in communications from the Ministry of Foreign Affairs and the Jakarta Embassy in June 1983. New Zealand's Ambassador reported that violations of human rights appeared to be decreasing to levels similar to those in other parts of Indonesia, implying that New Zealand had been aware of widespread abuses prior to this time, but had chosen not to consider them as issues for comment ${ }^{82}$.

What is striking about the collection of documents released under the Official Information Act is that, after an initial dearth of information, and well aware of the impact of Indonesian rule in East Timor, with Indonesia unlikely to ever win a complete military victory against FRETILIN, New Zealand continued to support Indonesia's presence there. Amnesty International reports received by the government about human rights abuses, including reprisals and extra-judicial killings, were accepted as "probably correct" 83 . Concern ran high in the Ministry as well as among the public about the welfare of the East Timorese, yet at no time does New Zealand appear to have reconsidered its policy of de facto recognition of the integration, in spite of that integration having been achieved in contravention of international law, giving a firm legal basis for any protest it sought to make.

\section{Confusing the issue}

The right to self-determination can arguably be considered as fundamental in international law, yet the violation of this most fundamental human right seems to have been accepted and subsequent violations which stem from it have instead been the object of criticism. New Zealand has

81 Eye-witness, Bob Muntz of Community Aid Abroad, refuted claims by the Indonesian military that a hand grenade, which did not explode, had been thrown at soldiers, and that a shot had been fired (cited in Gunn 1994, p.177)

82 Report by the New Zealand Ambassador in Jakarta on the situation in East Timor, June 9, 1983, paragraphs 10 \& 11; document released under the Official Information Act.

83 Ambassador Powles in a report received by the Ministry on December 4, 1984; document released under the Official Information Act. 
attempted to cure the symptoms of the denial of sovereignty while feeding the cause - the violation of East Timor's right to self-determination.

In November, 1994, Prime Minister, Jim Bolger attended the Asia Pacific Economic Cooperation (APEC) forum in Jakarta. He said prior to leaving for Jakarta that he did not intend raising the issue of human rights violations with President Suharto as this was a trade forum. Although consistent with New Zealand's stance on the issue, and with its reluctance to link concerns about human rights to other aspects of its relationship with Indonesia, it does seem unlikely that an opportunity to make informal comment did not arise. During the forum, protesters occupied the area in front of the United States embassy and widespread rioting broke out in Dili following the death of a Timorese at the hands of an Indonesian transmigrant. The Prime Minister instead emphasised trade and regional stability, the two issues which have shaped New Zealand's relationship with Indonesia and response to the conflict in East Timor.

\section{Entering the human rights debate}

The decision to favour discussion of human rights over sovereignty in East Timor is problematic. New Zealand has had to engage in the emotive discourse which seeks to define human rights and their extent; and to defend perceived differences in Asian and Western values.

International debate on human rights is characterised by an East-West divide; the individual human rights ideals articulated by Western states being dismissed in Asia as Western concepts to which Asians merely react ${ }^{84}$, or down-played in favour of community rights to economic development, peace and security. Pressure from Western states to improve human rights records is frequently described as meddling by states with little understanding of local realities, as the Myanmar delegate to the preparatory conference in Bangkok prior to the June, 1993, World Human Rights Conference in Vienna indicated:

Asian countries, with their own norms and standards of human rights, should not be dictated [to] by a group of other countries who are far distant geographically, politically, economically and socially. 85

\section{Applying international Conventions}

At the Bangkok Conference, former Thai Prime Minister Chuan Leekpai said the path towards realising the ideals of the Universal Declaration on Human Rights lies through economic

\footnotetext{
84 Kishore Mahubani, Singapore's deputy foreign secretary, cited by Ching, 1993, p.27.

85 cited in " Rights Thinking", Editorial of Far Eastern Economic Review, June 17, 1993, p.5.
} 
development, democratisation and social justice ${ }^{86}$, implying that these steps can be prioritised in that order. The declaration resulting from the Bangkok conference, presented in Vienna, calls for human rights to be:

considered in the context of a dynamic and evolving process of international norm-setting, bearing in mind the significance of regional particularities and various historical, cultural and religious backgrounds 87 .

The declaration insists on the principle of non-intervention and on economic development objectives. In Vienna it was criticised by the United States which saw it as justifying breaches of human rights standards, subordinating civil and political rights to economic, social, cultural, and development rights; and for making economic aid a precondition for improvements in human rights records ${ }^{88}$. Amnesty International warned before the Vienna conference that Asian governments would use the occasion to challenge the legitimacy of international action against human rights violators and assert the primacy of development issues over civil and political rights, claiming that individual rights are alien to their culture ${ }^{89}$. Such differences in perspective place parameters on the extent to which Western countries such as New Zealand can influence Indonesia without being dismissed as ignorant of local realities.

Indonesia has reacted strongly to attempts to link human rights to development assisatnce. The Netherlands especially, former colonial ruler of the Indonesian archipelago, has attracted the Jakarta's ire. Following the Dili Massacre, several countreis, including Canada, Denmark and the United States, as well as the Netherlands, suspended aid to Indonesia pending an investigation into the incident. Only the Netherlands had all of the development assistance it provided rejected by Indonesia "as a consequence of the reckless use [by the Dutch] of development assistance as an instrument of intimidation"90. Jakarta dissolved the Inter - Governmental Group on Indonesia (IGGI), a donor consorium presided over by the Dutch government. It requested the World Bank, itself a member of IGGI, to establish a new donor group including all former members of IGGI except the Netherlands.

86 cited by Frank Ching, 1993 "Asian View of Human Rights is Beginning to Take Shape" Far Eastern Economic Review, April 17, 1993, p.27.

87 UN Document A/Conf.157/ASRM/7.

88 Susumu Awanohara et al, 1993, "Vienna Showdown", Far Eastern Economic Review, June 17, p. 17.

89 Ching, 1993, p.27.

90 A senior Indonesian official, cited by Allert van den Ham, 1993, "Development Cooperation and Human Rights", Asian Survey, Vol. 33, No. 5, p.532. 
Bilateral relations between the two countries have always been characterised by tension but, van den Ham argues, it is difficult to identify a single cause for the decision to reject the Netherland's development assistance. He writes:

It seems there was a combination of sincere irritation with the Dutch policy and its implementation on the one hand, and political considerations in both the international and national arenas on the other. Indonesia needed a scapegoat and the Netherlands was an easy target at relatively limited costs. 91

Domestically, Jakarta's rejection of Dutch assistance was popular. MacIntyre suggests that as far as newspaper editorials and political cartoons are a guide, Western (and especially Dutch) sermons on human rights were not appreciated by Indonesians 92 . Internationally, Jakarta's action could be seen as a warning to other small aid donors to refrain from criticising Indonesia on human rights issues.

\section{State Terrorism in Indonesia}

Human rights standards as articulated in United Nations Conventions on Human Rights, although widely ratified, have been palpably ineffective in curbing abuses. This is particularly true of statesanctioned violence; Amnesty International has reported an increase in the use of torture and arbitrary detention and, in 1993, reported abuses in more countries than ever before in its history 93 .

Suharto's New Order government has been accused of human rights violations "on a staggering scale"94 since coming to power in 1965, not only in East Timor but throughout the archipelago. Amnesty argues that violations of human rights in Indonesia "have been part of the official response to political opposition and 'disorder', and the means of removing perceived obstacles to economic and development policies"95. The organisation notes that trade unionists, farmers, human rights workers, community leaders, students and journalists have all been subjected to

91 ibid., p. 538. Dutch aid to Indonesia in 1992 represented only $1.9 \%$ of the US $\$ 4.8$ billion donated by IGGI. When the World Bank convened the new Consultative Group on Indonesia in July, 1992, the group agrred to an increased level of support, committing over US\$ 4.9 billion for the following year, a net increase in aid of US\$909 million - Andrew MacIntyre, 1993, "Indonesia in 1992: Coming to Terms with the Outside World", Asian Survey, Vol. 33, No. 2, p.206.

92 MacIntyre, 1993, p. 206.

93 Amnesty International Report, 1993.

94 Amnesty International New Zealand News, September/October 1994, p.1.

95 ibid., p.2. 
severe human rights violations ${ }^{96}$ implying that economic growth is a goal which will be achieved not for the benefit, but at the expense, of human rights in Indonesia.

The newly constructed roads, schools and administrative buildings are displayed as evidence of Indonesia's efforts to develop East Timor. According to the misguided argument advanced by New Zealand that economic growth and development will improve human rights, these trappings of development should have brought about an improvement in the situation of the East Timorese. The new facilities have instead enabled the Indonesian state to extend its presence in East Timor. New Zealand's Ambassador noted, after a visit to East Timor, that most new construction was designed to house the "administrative machine, civil and military, that seems so essential to the Indonesian governmental system"97, the very system which perpetrates the abuses New Zealand is quietly attempting to curb, and were therefore not of benefit to the East Timorese.

New Zealand continues to support the Indonesian regime, whilst simultaneously professing concern about its abuses of human rights. This apparently untenable position is framed in terms of regional economic and security interests with some support from the Bangkok declaration that economic growth and development is the path to improved human rights. To a certain extent, New Zealand's concern for the 'welfare' of the Timorese is an effort to reconcile a tradition of defining human rights in terms of democratic government and personal liberty with support for the economic development of Indonesia. 'Welfare' suggests provision of services and the fulfilment of basic needs. It does not necessarily imply the extension of the individual political and human rights which are expected in a democratic society. New Zealand can thus call for improved welfare without implying criticism of Indonesia's political system.

The existence of international human rights Conventions and continued criticism of Indonesia's record from non-governmental organisations, governments, and the United Nations has had little impact on the frequency or severity of human rights violations in the archipelago, although it has encouraged Jakarta to emphasise the principle of non-intervention in internal affairs. With regard to East Timor, it is important for Jakarta that the territory is accepted as an integral part of Indonesia and thus better shielded from international scrutiny. However human rights, like ecological issues and labour laws for example, are increasingly being seen as sufficiently important international issues to override the principle of non-intervention. Concern for human rights does mask other motives, as Tremewan notes:

96 ibid., p.1.

97 Report of a visit by Col. J.S. Harman to East Timor, 26-30 November, 1984; document released under the Official Information Act. 
The dominant criteria for criticism of human rights abuses and for humanitarian intervention are likely to continue to be the degree of threat to the interests of industrialised countries and the relative willingness of third world states to cooperate with these countries rather than the severity of human rights violations or the scale of human need ${ }^{98}$.

Communications between the Ministry of Foreign Affairs and New Zealand's Jakarta Embassy, statements from Ministry officials, Members of Parliament and Parliamentary staff all indicate that the New Zealand government is well aware of the impact of Indonesian rule in East Timor including development initiatives, transmigration programmes and the extensive military presence. They also suggest that where East Timor is concerned, our relationship with Jakarta is of primary importance and cannot be put at risk.

The implication that New Zealand cannot afford to jeopardise its relationship with Indonesia suggests that the government would be more willing to take a stand on issues such as selfdetermination and human rights violations if this could be done with impunity. New Zealand has been portrayed by successive governments as a passive player, keeping its opinion to guarded. This impression is misleading. New Zealand has actively shown support for Indonesian annexation of East Timor on a number of occasions and has supported Indonesia in international fora. Howard suggests "East Timor is a touchstone for New Zealand' Foreign Affairs policy, whether it is to be measured on self-interest or on principle"99. To date, New Zealand foreign policy regarding East Timor has clearly been measured against self interest.

98 Tremewan 1993, p. 27.

99 Howard, 1994. 


\section{Chapter 5 \\ Heading for Change}

\section{The United States}

Like New Zealand, the United States formally supported self-determination for East Timor but within a short time indicated it accepted Indonesia's de facto control ${ }^{1}$. Britain, too, has declared its support for self-determination for the East Timorese and does not officially condone Indonesia's annexation of East Timor. But, in what is a familiar pattern, Britain did not interrupt relations with Indonesia and had, by 1985, become the largest Western European supplier of arms to the Suharto government ${ }^{2}$.

The United States' position on self-determination, although an internationally respectable statement to make, was belied by the apparent condonation of the invasion by President Ford and Secretary of State Henry Kissinger during their official visit immediately prior to the invasion. Strategic and economic interests have shaped the American relationship to Southeast Asia, and Indonesia in particular. President Eisenhower said in 1953, defending US\$400 million in aid to the French colonial government in Indochina, that losing Vietnam and Malaysia would also mean the loss of "the rich empire of Indonesia"3 . Rubber, oil and tin were the key strategic minerals which excited interest in Indonesia. Vice-President Nixon described Indonesia as "containing the region's richest hoard of natural resources"4. Six years later, Indonesia was considered by the US to be "endowed with what is probably the most strategically authoritative geographic location on earth."5

Indonesia was seen as a valuable prize and one easily lost. US policy toward Indonesia was thus concerned with maintaining access to strategic sea-lanes and raw materials, and with building anticommunist alliances. Human rights, decolonisation, economic development and political freedom were not issues with which the US chose to concern itself at that time. McCormick argues that strategic considerations were an important motivating force in the foreign policy of the Nixon and Ford administrations, and that this led to a reluctance to bring concerns about human rights

\footnotetext{
1 Robert Pringle, 1980 Indonesia and the Philippines: American Interest in Southeast Asia, Columbia University Press, New York, p.103.

2 Retboll 1987, p.31.

3 cited in Franke 1983, p.44.

4 Richard M. Nixon, 1967 “Asia After Vietnam”, Foreign Affairs, Vol. 46, No. 1, p.111.

5 cited in Franke 1983, p. 44.
} 
violations to the governments seen as important to the establishment of global order ${ }^{6}$. The global order envisaged by Kissinger, secretary of state in both the Nixon and Ford administrations, was predicated on preserving the nation state system, and attempting to manage that system by moderating conflict among major powers. Falk sees a conceptual flaw in this approach:

It accepts as inevitable the persistence of large-scale misery and repression. It enables the disfavoured many to be kept under control by the favoured few. The global structure of control that Kissinger envisages and endorses tempts change-minded groups to adopt some variant of "desperate politics" to achieve their goals of liberation from social, political and economic oppression. ${ }^{7}$

Certainly, when assessing the threat posed to the integrity of Indonesia by an independent East Timor, the United States considered the preservation of the nation-state to be of greater importance than the principle of self-determination. During his visit to Jakarta prior to the invasion of East Timor, President Ford announced an increase in military assistance to Indonesia of 450 percent ${ }^{8}$. During congressional hearings on East Timor in March, 1977, Lt General Howard Fisk of the US airforce testified that US military equipment was used in the invasion of East Timor9.

The Carter administration took a more idealistic approach to foreign policy and emphasised human rights. Aid, particularly military aid, was suspended to nations whose human rights records were offensive to the US. Chile, Argentina, Uruguay, Guatemala, Nicaragua, Vietnam, Cambodia, Uganda and Mozambique had aid grants reduced or cut completely ${ }^{10}$. In spite of a desire to see an improvement in human rights, Indonesia was not pressured to conform. No such suspension of aid to Indonesia was implemented ${ }^{11}$. The Carter administration did not change US policy toward East Timor in any fundamental way, nor did it criticise the invasion of East Timor. The US did not, under Carter, support UN resolutions calling for the withdrawal of Indonesian troops form East Timor, or the implementation of an act of self-determination.

\footnotetext{
6 James M. McCormick, 1992 American Foreign Policy and Process, F.E. Peacock Publishers Inc., Itasca, Illinois.

7 Richard A. Falk, 1975 "Whats Wrong with Henry Kissinger's Foreign Policy?" cited in McCormick, 1992 , p.135.

8 Sidell, 1980, p.48.

9 Congressional hearings had commenced on March 13, 1977. Former Australian Consul to East Timor, James Dunn, provided accounts of Indonesian atrocities in East Timor based on interviews with refugees - Taylor, 1992, p.202.

10 McCormick, 1992, p. 145.

11 Pringle 1980, p.106.
} 
Compared with its response to human rights abuses in the Philippines, the US seems to have acquiesced in oppression by the Suharto regime. Institutionalised restrictions on the press, individual liberties and academic freedom grew more widespread in Indonesia, and the number of political detainees greater ${ }^{12}$, yet Indonesia was not subjected to the degree of public protestation of human rights abuses that the Philippines was, nor did the US abstain from international financial institution loans as it did for the Philippines ${ }^{13}$. Aid to Indonesia was not curtailed, and military assistance continued, including the provision of aircraft which had a particularly counter-insurgent function $^{14}$.

The anti-communist credentials of Suharto, and the apparent leftist character of the East Timorese resistance movement, ensured support for the Indonesian regime during the Reagan administration. President Reagan expressed concern about the existence of military rule in Poland, about human rights violations in Nicaragua, and the invasion of Afghanistan by the Soviet Union, but set these same concerns aside when he considered Indonesia ${ }^{15}$. During a visit to Washington by President Suharto, Reagan stated that he viewed Indonesia as a force for peace, stability and progress and praised Suharto's efforts at nation-building ${ }^{16}$. The strategic value of Indonesia meant the stability of the Republic was important. Chomsky has noted that the US government and media had little to say about the conflict in East Timor, particularly when compared with the interest taken in Cambodia ${ }^{17}$.

It would be incorrect, however, to present all members of the US government as having been disinterested the East Timor issue, or having dealt with it expediently, prior to the Clinton administration. Members of the US Congress have been active on this matter through successive administrations. Secretary of State George Schultz was pressured by 22 senators to raise East Timor as an issue during a 1984 visit to Jakarta. The following year, 131 members of Congress expressed their concern about the situation in East Timor to President Reagan prior to a visit to Lisbon. In 1987, 40 members of the Senate publicly criticised Indonesia's occupation of East Timor and in 1989, 100 members od Congress called on the State Department to launch an official

12 Pringle, 1980, p.104.

13 Pringle 1980, p.106.

14 OV-10 Bronco aircraft can carry a heavy ordnance including bombs, rockets, machine guns and napalm (reportedly used in East Timor), as well as infra-red detectors. They have been described as the most versatile and deadly counter-insurgency aircraft in the world. They are slow moving and specifically designed for use against an enemy lacking anti-aircraft capability - Sidell 1981, p.47-48.

15 Retboll, 1987, p.31.

16 ibid.

17 Necessary Illusions, Manufacturing Consent: Noam Chomsky and the Media, 1992. 
enquiry into claims of torture of East Timorese by the Indonesian military after a visit to Dili by the Pope ${ }^{18}$. The interests of the legislative and executive branches of the US government have coincided on this issue under the Clinton administration, as discussed shortly.

\section{The United States in the United Nations}

Following the invasion on December 7, 1975, diplomatic activity shifted from the embassies of the US, Australia, Portugal and Indonesia, to the United Nations. Approval for Security Council Resolution 384 of December 22, 1975, calling for withdrawal of Indonesian troops from East Timor, had been unanimous. However, Security Council Resolution 389 which repeated this demand the following April, was not. Both America and Japan had abstained from voting ${ }^{19}$. In December, 1976, the US voted against the General Assembly Resolution calling for the withdrawal of Indonesian troops, establishing the pattern followed by New Zealand and Australia. And like Australia and New Zealand, the US continued to vote against General Assembly Resolutions including 34/40, which declared that "the people of East Timor must be enabled freely to determine their own future under the auspices of the United Nations"; and resolution 35/598, which reaffirmed "the inalienable right of the people of East Timor to self-determination and independence, in accordance with the Declaration on the Granting of Independence to Colonial Countries and Peoples, contained in General Assembly resolution 1514(XV)"20.

Once again, official rhetoric supporting the right of the Timorese to self-determination was not supported by government action. In fact, Franke argues, the US made a concerted diplomatic effort to weaken support for East Timor in the United Nations. Not so much because Indonesia was a valuable trading partner and an important component in US security designs, but because a US foreign policy goal was to break up blocs of nations, mostly the new UN member states who were the most vehement supporters of the principle of self-determination, which collectively posed a threat to US interests ${ }^{21}$. In his memoirs, American Ambassador to the United Nations at that time, Daniel Patrick Moynihan, was specific about the role of the US in confounding UN action on East Timor, writing that the "Department of State desired that the United Nations prove utterly ineffective in whatever measures it undertook" 22 .

\footnotetext{
18 Taylor, 1991, p.212.

19 Franke 1983, p.53.

20 Franke 1983, p.53. - find a reference in UN library instead of Franke.

21 Franke 1983, p.53-54.

22 Daniel P. Moynihan, 1978 A Dangerous Place, Little Brown \& Co., Boston. p.247.
} 
New Zealand's efforts to define the problem of East Timor's sovereignty out of existence had a precedent in the United States. In March, 1977, State Department officials acknowledged that the annexation of the East Timor was a fait accompli; the United States recognised the annexation and the legality of the exercise of sovereignty there by the Indonesian government ${ }^{23}$. And just as in New Zealand, American policy on East Timor has remained essentially unchanged under both Democratic and Republican administrations. The Carter administration continued the policy established by President Ford and Secretary of State, Henry Kissinger. It is only under President Clinton that East Timor has again become a contentious issue in United States' foreign policy.

\section{Practical support for Indonesia: the arms trade}

Sidell argues that American military support has been crucial to Indonesia's capacity to maintain its position in East Timor. A generous supply of counter-insurgency equipment, including aircraft, vehicles, patrol craft, arms and ammunition, enabled Jakarta to extend its authority over most of East Timor, at the expense of FRETILIN ${ }^{24}$. Although the US is the primary source of arms for Indonesia, several European countries have given military assistance to Indonesia. The arms trade continues despite European parliament resolutions condemning abuses of human rights in East Timor by armed forces personnel.

Indonesian Minister for Research and Technology, B.J. Habibie, was charged with the task of creating an Indonesian high-technology industry, with a special focus on military equipment. Production was stimulated by obtaining manufacturing licenses from overseas companies, many of them European ${ }^{25}$. Belgian companies produce arms under license in Indonesia, including rifles, machine guns and rockets ${ }^{26}$; German company MBB became involved in a joint venture to produce helicopters. The Lurssen Shipyard has also entered into a joint venture under the auspices of Habibie, building attack craft and patrol boats for the military 27 . The practice of building arms locally under licence enables German arms manufacturers to circumvent German law, which allows arms exports only in exceptional circumstances ${ }^{28}$. Exports of arms are not uncommon however; total German exports to ASEAN in 1993 equalled DM 45276 million.

\footnotetext{
23 Franke 1983, p.54.
}

24 Scott Sidell, 1981 "The United States and Genocide in East Timor", Journal of Contemporary Asia, Vol. 11, No. 1, p.48.

25 Buko, 1994 "Germany" in Martin Broek (ed), Stop Arming Indonesia: A European Perspective on Arms Trade to a Military Regime, European Campaign Against Arms Trade, Amsterdam, p.46.

26 Ernst Gulcher, 1994 "Belgium”, in Broek (ed), p.45.

27 Buko 1994 , p.47.

28 ibid., p.46. 
Sweden supplied arms to the colonial administration of the Dutch East Indies and trade continued following independence. Swedish governments have not always been comfortable with arms trade with Indonesia, however. Exports were stopped during the confrontation with Malaysia (1963-66) and did not resume until $1975^{29}$. Following the invasion of East Timor, the Social Democrat government advised arms manufacturers not to enter into export agreements with Indonesia, but did not prevent them. When the Social Democrats returned to power in 1982, after a four year period in opposition (during which they were highly critical of continued arms exports), Prime Minister Olof Palme approved the continued sale of arms to Indonesia, stating that "according to reliable sources, there is no fighting in East Timor at this moment" 30 . Opposition to arms exports was renewed following the 1991 Dili massacre, but by this time the Social Democrats were again in opposition, and exports continued.

The Netherlands has maintained a close relationship with Indonesia since independence, although this has been marred by Sukarno's nationalisation of Dutch industries in 1956, the bloody aftermath of the 1965 and 1966 coups, and the 1975 invasion of East Timor. Military ties have never been severed, however, only suspended ${ }^{31}$. Indonesia is a principle target for Spanish arms exports, receiving $80 \%$ of Spain's arms exports to Asia in the $1980 \mathrm{~s}^{32}$. Indonesia is also a major recipient of Spanish development aid; only Mexico and China receive more ${ }^{33}$.

Between 1988 and 1992, Indonesia was the sixth biggest recipient of British weapons systems. Only Saudi Arabia, India, the United States, Oman and Denmark received more. In addition to arms, Britain provides training for Indonesian military personnel, both in the UK and in Indonesia ${ }^{34}$. The British government does not consider military links to be a contributing factor in human rights abuses in Indonesia, and says it does not grant export licences for equipment likely to be used in internal security operations ${ }^{35}$. In spite of these assurances, East Timorese have reported seeing British Aerospace Hawk aircraft being used in counter-insurgency operations ${ }^{36}$.

29 Swedish Peace and Arbitration Society, 1994 "Sweden" in Broek (ed), p.58.

30 ibid., p. 59.

31 Niek van Essen, 1994 "Netherlands" in Broek (ed), p.51.

32 Arcadi Oliveres, 1994 "Spain: Interests in the Region" in Broek (ed), p.55.

33 ibid.

34 Campaign Against Arms Trade, 1994 “United Kingdom”, in Broek (ed), p.66.

35 ibid.

36 Death of a Nation - The East Timor Conspiracy, Independent Television, Britain, 1993. 
Following the change of government in Portugal, Britain, like the United States and Australia, had considered the possibility of an Indonesian invasion of East Timor and reached the conclusion that it was in Britain's interest that Indonesia should absorb the territory as quickly and unobtrusively as possible. The British Ambassador to Jakarta also noted that "if...there is a row in the United Nations, we should keep our heads down and avoid siding with Indonesia"37. Once again, a government decided that whilst it desired an Indonesian East Timor, it did not wish to be seen to be ignoring the political and moral principles at stake. Britain does not officially condone Indonesia's annexation of East Timor but has accepted Indonesian rule there as de facto.

It is not only arms which are exported, but expertise, prototypes and manufacturing equipment. These ensure that Indonesia will able to keep its military supplied with the equipment necessary for its internal security activities, regardless of whether foreign governments suspend military assistance.

That Indonesia continues to exist as a unitary state can largely be attributed to the role of the military in government. The military has been able to sustain its position, and its internal security operations, because of the arms and training supplied by foreign governments. Without the capacity for repression of internal unrest which imported military hardware provides, it seems unlikely that Jakarta would have would have been able to maintain its control over East Timor in the face of widespread and persistent resistance. Thus, members of the international community have ensured Indonesian control of East Timor through concrete action, as well as through diplomatic inaction. This further undermines the professed support for the right of the East Timorese people to self-determination.

Governments have not been unaware of reports of human rights violations and atrocities in East Timor, particularly following the reporting and broadcast of the Dili Massacre in 1991, yet have maintained trade and security links with Indonesia. Sidell notes that: "the United States' official support for Indonesia has done little to curtail human rights violations in East Timor, and conversely has sustained and encouraged harassment, degradation and devastation of the East Timorese people" 38 . The Dili massacre prompted the European Parliament to recall its resolutions on the "internationally condemned illegal invasion by the Indonesian forces" and express its shock at the the evidence presented in a 1993 documentary Death of a Nation - The Timor Conspiracy,

\footnotetext{
37 cited in Retboll, 1987, p. 30.

38 Sidell 1981, p.53.
} 
and at subsequent reports of further killings ${ }^{39}$. Portuguese representatives have been instrumental in keeping the Timor issue alive in the European Parliament.

\section{The Clinton administration}

Human rights have been an important theme in the foreign policy of the Clinton administration, and this has had a tangible effect on relations with Indonesia. For example, the transfer of F5 fighters in August, 1993, was blocked ${ }^{40}$, and the sale of small arms to Indonesia was banned by the US Senate in July, 1994, until significant progress was made on human rights violations ${ }^{41}$. An amendment to the Foreign Aid Authorisation Bill, which linked human rights to arms sales in East Timor, also increased pressure on Jakarta ${ }^{42}$. The Feingold amendment would have prohibited government and commercial arms sales until the President certified that Indonesia has granted access to East Timor by human rights groups, that violations of human rights by the military have ceased, and Indonesia has complied with Security Council resolutions calling for the withdrawal of troops from East Timor and the implementation of an act of self-determination ${ }^{43}$. The Foreign Aid Authorisation Bill was not passed, which, Feith notes, has been usual in recent years 44 so to Jakarta's relief, the Feingold amendment did not become law.

The Clinton administration also reversed the US position in the UN Commission on Human Rights; in 1993, the US co-sponsored resolution 1993/97 with the European Community and Canada, calling on the Secretary General to present a comprehensive report on the question of East Timor $^{45}$. Congress has been instrumental in keeping the East Timor issue alive, and in pressuring Clinton to take action. Congressional prompting led Clinton to raise the issue of East Timor with Suharto at the 1993 G7 summit meeting in Tokyo, and at the APEC summit in Jakarta in November, $1994^{46}$. Indonesian labour practices have also attracted the attention of the United States. In June, 1993, US Trade Representative, Mickey Kantor, announced that US\$800 million

39 "Resolution on the exposure of the massacre in East Timor" March 10, 1994, reproduced in Broek (ed), 1994.

40 McMahon, 1994, p. 10.

41 Patrick Walters, 1994 “Clinton Steps Up Protest on East Timor”, The Australian, July 19, p.1.

42 McMahon, 1944, p.10.

43 Matebian News, Vol.1, No.5, p.6.

44 Herbert Feith, 1993 The East Timor Issue After the Capture of Xanana Gusmao, East Timor Talks Campaign, Melbourne, p.7

45 “United Nations Move Further on East Timor", Matebian News, Vol.1, No.10, February, 1994, p. 2. 46 ibid. 
per annum of Indonesian exports to the US were threatened unless Indonesia demonstrated a committment to labour rights, especially freedom of association 47 .

America's confrontational handling of human rights issues in Asia has attracted criticism from Australia. Senator Evans criticised the US decision to link China's most favoured nation status to human rights activities, noting that Australia favoured the use of dialogue and international fora and believed that economic growth is the key to political freedoms ${ }^{48}$. Australian Ambassador to the US, Dr Don Russell, has questioned American handling of its relationship with Indonesia, particularly. He believes the US does not appreciate the importance of Indonesia in ASEAN and in the region 49 . In spite of the re-evaluation of what the US perceives to be its interests in the Asia Pacific region, the bilateral relationship with Australia remains strong 50 .

Australia's geographical proximity to Indonesia has clearly led to it forming a different perspective on Indonesia's strength and importance to regional stability. Australia's pragmatic approach to Indonesian rule in East Timor does not appear to match the more idealistic approach taken by the Clinton administration, with its emphasis on human rights. However McMahon argues that US concern over human rights masks an approach to Indonesia's declining strategic importance which is based in realism, providing an excuse to disengage with the Suharto regime ${ }^{51}$. McGregor notes that by identifying democracy and human rights as security concerns in Asia, Washington has indicated it is concerned with how states in the region govern, and in who governs them ${ }^{52}$. Ruling elites are thus threatened for being anti-democratic, rather than protected as stable allies. Unfortunately this analysis is unlikely to be of comfort to Australia, which will almost certainly experience the effects of political upheaval in Indonesia.

47 Feith, 1993, p.6-7.

48 Joseph M. Siracusa, 1994 "Problems in Australian Foreign Policy January - July 1994", Australian Journal of Politics and History, Vol.40, No.3, p.300.

49 Siracusa, 1994, p. 301.

50 Paul Dibb cited in Siracusa, 1994, p.298.

51 McMahon, 1994, p.10.

52 Charles McGregor, 1993 “Southeast Asia's new Security Challenges”, The Pacific Review, Vol.6. No.3, p.269. 


\section{Conclusion}

\section{The changing face of government in Indonesia}

Much has changed since Indonesia first cast a covetous eye over East Timor. Not least is the position of the military in Indonesian political life. Although still pervasive, military influence in Suharto's government appears to be on the wane. A change in the international environment has made tacit support for Indonesia's position with regard to East Timor less certain. Continuing reports of human rights abuses by Indonesia in East Timor have attracted criticism from many quarters, including the European Union, the United States and New Zealand (however faint). There are indications that Indonesia recognises the status quo cannot be maintained; UN sponsored talks between Indonesia and Portugal over the future of the territory have resulted in an agreement by Indonesia to open informal links with Timorese opposed to Indonesian rule ${ }^{1}$. Indonesia is reducing the number of troops stationed in East Timor and is making an effort to make the remaining military presence less obvious ${ }^{2}$. Such actions are tactical concessions however, and do not necessarily indicate a change of attitude by Jakarta.

Vatikiosis and Robison argue the military is divided over the extent to which it must redefine its role, and the ideological basis for its role, in order to ensure its continuing ability to influence government; it must address popular demands for a greater degree of democracy but is unwilling to initiate any reforms that might result in a reduction of its own power or lead to a questioning of its continued influence in civil affairs ${ }^{3}$. Persistent reports of atrocities committed in East Timor have highlighted tensions within the military leadership between those who recognise the need to address international criticism of Indonesia's human rights record, and those whose main concern remains the security and integrity of the Republic. The Dili massacre of November 1991 threw into sharp relief the difference between Indonesia's new image as an example of successful economic development and the repressive tactics used to maintain the image of political and economic stability. The closure in June 1994 of three weekly magazines critical of the government (Editor, Tempo, and De Tik) the subsequent protests and harsh police response hardly suggest that the government has resolved this internal argument or become any more accommodating of dissent since then.

Robison notes the growth of important new social forces in Indonesia: a capital owning class, a middle class, a working class and a ubiquitous urban underclass of unemployed, underemployed and petty traders. He notes however that the groups which elsewhere have proven the progressive forces of

\footnotetext{
1 Reuter News Service, "Indonesia Captures Timor Underground Leader", May 20, 1994, Jakarta.

2 Cohen 1993, p.24.

3 Vatikiosis, 1993, p.76; Robison 1993, p.54.
} 
democratic reform, the middle and capital owning classes, have been less effective in Indonesia where fears that a retreat from authoritarianism will engender instability predominates ${ }^{4}$. Changes in the global and local economic climate have serious implications for Indonesia's political order, however. The privileges accorded to senior military personnel, politicians and civil servants who controlled the monopolies which were characteristic of Indonesia's import-substituting development strategy are being curtailed. As Indonesia moves toward an export-oriented development strategy, foreign investment is becoming increasingly widespread ${ }^{5}$ and the influence of the state is declining. Greater reliance on foreign loans and investment has made the state susceptible to demands from foreign investors for reforms to the state apparatus to allow for better accountability and transparency ${ }^{6}$.

Corea warns that the pressures of global capitalism are a powerful challenge to integrity of modern states, particularly less developed states. He writes:

Third world countries are one by one becoming ungovernable. No matter what the complexion of the governments - right wing, left wing, democratic, military - they are all in situations of not being able to respond adequately to the expectations of their people; expectations aroused by the media, communications, education...7

Reduced military influence in civil affairs will not necessarily bring about a change in the status of East Timor. As long as armed resistance by Timorese continues, the military will use this to justify their extensive security measures. The perpetuation of the Timor conflict has served many in the armed forces well. It has provided an opportunity for career-minded personnel to obtain field experience, invaluable when seeking promotion ${ }^{8}$. It has also enabled those who have limited career prospects in the armed forces to secure prestigious civilian positions on retirement; middle-ranking military personnel who serve for extended periods in East Timor are able to build up local bases of support and power ${ }^{9}$. The development of local power bases by military personnel has gone unchecked. The editors of the journal Indonesia, in their annual report on the Indonesian military, argue that the extent to which these power groups were operating independently from the central military command was evident at the time of the 1991 Dili massacre. Although Suharto publicly dismissed the two senior military personnel in East Timor, Brigadier-General Warouw and General Panjaitin, thereby distancing himself from those

4 Robison, 1992, p. 338.

5 Jonathan Rigg, 1991 Southeast Asia: A Region in Transition, Unwin Hyman Ltd., London, p.182.

6 Robison,1992, p.348.

7 Gamani Corea, chair of the UNGA Committee on International Development Strategy for the 4th United Nations Development Decade - cited in Falk \& Camilleri, 1992, p.57.

8 Editors, Indonesia, 1993, p.120.

9 Editors, Indonesia, 1992, p.98. 
who supported the hard line taken in Dili, the editors argue that the massacre occurred without their orders, and probably without their knowledge. Rather, it was ordered by local military commanders eager to discredit Warouw whose assigned task was to clean up the local military establishment. Indonesian military and administrative personnel may prove reluctant to give up their local interests and actively discourage efforts to resolve the conflict.

President Suharto, in his twenty-ninth year in power in 1995, was under increasing pressure to resign. ${ }^{10}$ When his term in office ends in 1998, he will be 76 years of age. Although he continues to hold almost absolute constitutional and political authority in Indonesia, apparent tensions between Suharto and the military over the appointment of a successor, and Suharto's efforts to replace key figures in the bureaucracy with civilian appointments, suggest he is unlikely to retain the support of the armed forces should he decide to stand for another term ${ }^{11}$. Furthermore, Suharto's successor is unlikely to sustain the concentration of power currently invested in the presidency.

\section{No capacity to resolve the Timor conflict}

The conflict in East Timor has lost its ideological edge, if indeed it ever had one. As discussed in chapter four, FRETILIN did not identify itself as ideologically radical; left-wing radicalism was projected onto the organisation by Indonesia and others to provide justification for Indonesia's reluctance to see East Timor become independent. Resistance against Indonesian rule is nationalist in character, and is also a protest against the structural dominance of Indonesians, and widespread corruption, which exclude East Timorese from power. There is no room for expression of political dissent in Indonesia's political system however, so the fight for social justice, like that for selfdetermination, must occur outside the framework of civil debate. This means that protest by the Timorese is exactly the sort of threat to Indonesia's integrity which the military, in its dual role, is charged to counteract. But as long as Indonesia continues to use military tactics to quell political unrest, resistance to Indonesian rule will continue. Indonesia has indicated it is unwilling to make the fundamental changes in its political structure which would enable participation in government by the East Timorese to a degree which would address Timorese grievances and award a sufficient degree of autonomy to make calls for self-determination redundant. Taylor points out that in the case of East Timor, demands for recognition as a nation entail demands for state sovereignty as well ${ }^{12}$. Autonomy is not enough which creates a psychological barrier to reaching a settlement.

10 James Dunn, Turnbull House, Wellington, June 29, 1994.

11 Murdoch, 1994.

12 Taylor, 1989, p.190. 
Nor is the government willing to make the psychological shift necessary to see the resistance of the East Timorese as a political protest which cannot be solved by measures aimed at improving the economic welfare of the East Timorese. Regional commander, Major General Adang Ruchiatna, said in 1994 that the Timorese had been ungrateful for Indonesian development; that Jakarta had provided more money and resources to develop East Timor than any of its other 26 provinces; and that seven battalions of soldiers were in East Timor to improve the lives of the people ${ }^{13}$. He explicitly identified economic development as the key to addressing resistance, ignoring the legitimate legal and political grievances of the East Timorese. This fundamental misunderstanding of the nature of Timorese resistance does not bode well for attempts to resolve the conflict. Rather, it suggests that the cycle of resistance and repression will continue.

\section{The international community: not a catalyst for change}

Dunn has characterised the international response to Indonesia's annexation of East Timor as "a cruel conspiracy against a small and vulnerable people"14. When decolonisation was initiated in East Timor by the Portuguese, support for Indonesian annexation was immediately forthcoming from Australia and the United States. Enthusiasm for the outcome of Indonesia's invasion and formal incorporation of the territory was masked by professed support for the right of the East Timorese to self-determination. Statements to this effect were made during the period of decolonisation by Portugal and following the invasion by Indonesia. 'Self-determination' can thus be understood to mean the right to freely decide the future political status of East Timor. Little has been done ensure the exercise of this right however.

Unwillingness to actively support this principle stems from the perception that an integrated East Timor, and a stable Indonesia, is in the best interests of individual governments, be they strategic or economic interests. These interests tend to be defined narrowly, and therefore place narrow parameters around the response of governments. A broader definition of security and state interests might include political, cultural and social relations within other states as well as between them. The human rights debate is symptomatic of a broad approach to security. This approach oversteps the traditional bounds of international relations, which views states as the smallest unit of analysis and relegates 'domestic' affairs to other disciplines. It also challenges the power politics, or realist approach which governments tend to adopt. However, the pragmatic approach taken by members of the international community, coupled with the principles espoused by them, suggests that if an independent (or even autonomous within the Republic of Indonesia) East Timor comes to be seen as beneficial to the interests of the international community, active support for self-determination will become a feature of foreign policy.

\footnotetext{
13 Lindsay Murdoch, 1994 “Timor Not Tamed, Indonesians Admit”, The Age, April 18, p.11.

14 Dunn, 1983, p. xiii.
} 
Because the status quo is perceived to be satisfactory, governments currently respond to allegations of human rights abuses by the Indonesian military, and reports of ongoing armed resistance by the East Timorese, as if East Timor is, de jure, a part of Indonesia. They are seen as a domestic issue. Thus, despite professed support for the principle of self-determination, Jakarta is the focus of efforts to improve the well-being of the Timorese. Better discipline in the military and economic development are prescribed as remedies for what is rotten in the province of East Timor. Other common features of the response of members of the international community - notably attempts to redefine events in East Timor, or deny a link between support for the Suharto regime and the actions of the military, in such a way that they do not implicate the government in the abuses. For example, Britain's assertion that military ties are not a contributing factor in human rights violations ${ }^{15}$, and Gareth Evans argument that the Dili massacre was carried out by rogue elements in the armed forces ${ }^{16}$. Governments are clearly sensitive about being seen to support a regime which perpetrates abuses of human rights, using equipment readily supplied by them.

The catalyst for change in East Timor is unlikely to come from the international community, but from within Indonesia. Imminent changes in Indonesia's political landscape offer the potential for East Timorese to assert their right to self-determination and express their dissatisfaction with the status quo. Whether this happens in a context of political upheaval and turmoil in Indonesia, or following a democratic process involving referenda, is unclear. What is clear is that the status quo is untenable. Resistance to Indonesian rule is persistent, and is costly for Jakarta. Resistance to Indonesian rule has become a part of the culture of East Timor. The sense of being an oppressed people is an important part of East Timorese identity. Such pivotal events as the capture of guerilla leader Xanana Gusmao, the murder of Sebastio Gomes ${ }^{17}$ and the subsequent Dili massacre, provide a focus for Timorese frustrations.

Taber argues that few governments can withstand the political, psychological and economic stresses of guerilla war, no matter how strong they are militarily ${ }^{18}$. Indonesia is in the six-sided box described by

15 op cit
16 op cit

17 Following a memorial service for Sebastio Gomes who had been shot by Indonesian troops, mourners walked toward the Santa Cruz cemetary. Banners protesting Indonesian rule and calling for selfdetermination, which had been prepared for the visit of a Portuguese parliamentary delegation (which had been cancelled), were unfurled during the procession. Indonesian troops opened fire on the mourners, although eyewitness Alan Nairn of New Yorker magazine said there was no provocation from the crowd who had arrived at the cemetary and were milling around peacefully - "In Cold Blood - The East Timor Massacre", Yorkshire Television, 1992.

18 Taber 1969, p.27. 
American official Sorenson, referring to the US position in the Vietnam war ${ }^{19}$ : the primacy of the Indonesian military cannot produce a complete victory, yet Jakarta's political primacy cannot permit a withdrawal; Jakarta cannot 'Indonesianise' the East Timorese, nor can it break their will to resist; escalation of the conflict risks censure from the international community, yet negotiations threaten the stability of the archipelagic state.

Beyond the geo-politics and geo-economics which have formed the basis of the responses of Indonesia, Australia, New Zealand and others to the decolonisation of East Timor lie fundamental legal issues. Indonesia's invasion and occupation of East Timor are illegal. Although the international community has attempted to avoid addressing the questions raised by the conflict by behaving as if Indonesian control of East Timor is indeed irreversible and beyond its control, the conflict, and the questions, persist. How Timorese demands will be met, what the role of the United Nations will be, and who will respond first to calls for justice from the East Timorese people have yet to be decided. The answer to one question is clear: no, resistance to Indonesian rule cannot be crushed.

The final statement of this dissertation belongs to Agio Pereira of the National Council for Maubere Resistance $^{20}$ :

I believe, ultimately, that the Indonesian armed forces will have to withdraw and the Timorese people will finally exercise their right to self-determination and independence. I believe that one day Xanana Gusmao will come out of his Indonesian prison and lead a healthy, democratic and happy nation. He will be able to say, like Nelson Mandela said after the recent South African elections: Free at last!

19 Theodore Sorenson, adviser to President Kennedy, likened the US position to "a six-sided box which we did not intend to make and cannot seem to break". He described the box thus: "Our worldwide military primacy cannot produce a victory, and our worldwide political primacy cannot permit a withdrawal. We are unable to transfer our will to the South Vietnamese and unable to break the will of the North Vietnamese. Any Serious escalation would risk Chinese or Soviet intervention, and any serious negotiations would risk a Communist South Vietnam" - cited in Taber 1969, p.15.

20 Agio Pereira, 1994 “Against Selective Amnesia: The Tragedy of East Timor”, Evatt Papers, Vol. 2, No. 1, p. 117 . 


\title{
Appendix
}

\section{Progress on the Lictenstein Initiative on Self - Determination}

\author{
Outcome of the Informal Meeting of Experts, pursuant to the 1991 UN General Assembly's Discussion of \\ the Liechtenstein Proposal on Self-Determination. \\ The following is a Summary Report by the Chair.
}

The informal Meeting of Experts was convened by the Government of Liechtenstein, and was held in Schaan, Liechtenstein, from 16 to 18 March 1993. The Government of Liechtenstein appointed Ambassador Claudia Fritsche (Permanent Representative of the Principality of Liechtenstein to the United Nations) and Sir Arthur Watts QC (Adviser to the Government of Liechtenstein) jointly to take the Chair for the Meeting.

The purpose of the Meeting was to assist the Government of Liechtenstein in further developing the ideas in the matter of self-determination advanced initially by His Serene Highness Prince HansAdam II, Head of State of the Principality of Liechtenstein, in his statement at the 46th session of the General Assembly in 1991, and further explained in subsequent statements by representatives of Liechtenstein. The meeting was attended by His Serene Highness and by 46 participants, nominated in their personal capacities by State Members of the United Nations and by States with Observer status, and by certain governmental and non-governmental organisations.

Included in the documents which participants had before them at the Meeting was a Memorandum summarising the main elements of the suggestions being put forward by Liechtenstein. A copy of that Memorandum is attached.

\section{General discussion}

The meeting began with a general discussion of issues raised by the Liechtenstein initiative. Overall, it was widely welcomed by participants as a valuable contribution: problems having their roots in the frustrations of distinctive communities within States were recognised to be urgent and important. At the same time, it was recognised that the whole subject was of considerable sensitivity, and that some particular ideas gave rise to certain difficulties

Several participants noted that 'self-determination' was a complex concept, based on broad notions of democracy and the rights and liberties of individuals.

It was also widely commented that 'self-determination had primarily developed in the struggle against colonialism, and the eventual attainment of independence in that context. But the concept had evolved, and its meaning in the modern world was more complex. A new generation of selfdetermination problems had arisen, and the international community had to re-think its approach. Selfdetermination now sometimes seemed to carry with it the danger of the fragmentation of States; this had to be avoided. The outcome of self-determination was not necessarily independence or border changes.

The Liechtenstein initiative was widely seen as looking towards new law and new structures, and as opening up new developments in application of the principle of self-determination. While still within the broad framework of that principle, and not necessarily excluding the attainment of independence, it was seen as being more related in practice to forms of development not going as far as independence or the break-up of States through secession or otherwise.

It was noted that the Liechtenstein initiative put the emphasis on the development of new structures within the State, and in particular on forms of territorial decentralisation or autonomy (i.e. 'internal' self-determination, as compared with 'external' self-determination, which manifested itself in notions of independence and sovereignty). Several participants accordingly suggested possible advantages in departing from the terminology of self-determination as the defining principle of the Liechtenstein initiative.

While some participants noted the possible danger that the Liechtenstein initiative could be used to limit further developments in self-determination and to defend the status quo, most saw it as without prejudice to that principle, as co-existing with it, and as indeed underpinning it rather than the reverse.

Several participants noted that the questions arose as to whether, once a State had attained independence through the exercise of the right of self-determination, groups within that State had a further right to self-determination for themselves - and then, perhaps, so on ad infinitum. Self-determination needed to be balanced against the need for new States to build their nationhood, and establish their internal stability. It was necessary to guard against the abuse of self-determination through the encouragement of separatism.

The Meeting then turned to a consideration of a number of particular issues. 


\section{Concept of 'Community'}

There was general support, in principle, for the introduction of a new concept such as 'a community' as the basic unit in terms of which rights of autonomy might be developed. It was helpful in underlining the departure from existing ideas in this field, and was appropriate for the autonomy-related focus of the Liechtenstein initiative rather than for the independence-related focus of existing provisions on selfdetermination.

The need for a 'community' to be essentially territorially based was generally accepted. But potential difficulties of definition were identified in a number of areas. These included: the relationship with the notion of nationality; the territorial identity of a 'community', and the problems of covering communities which were territorially scattered or fluid, or living in cross-frontier areas; the distinctive qualities which a 'community' should possess; their size; the need for flexibility in definition, to take account of the varying factors which give a community its particular identity; the economic factors which often determine the identity of a community; and the relationship between the definition of a community and the degree of autonomy it possesses.

The distinction between 'community' on the one hand, and 'minority' and 'indigenous people' on the other, was noted by many participants, as was the partial overlap between the various concepts.

Emphasis in the Liechtenstein initiative on the position of communities was seen by a number of participants as placing it in the context of collective human rights.

\section{General safeguards}

Possible safeguards were seen by some participants as really involving the checks and balances which would be necessary to make a new system work effectively. They were the forms through which compromises could be sought. It was acknowledged that some checks and balances would be necessary.

It was noted that 'safeguards' depended on the point of view: a safeguard for the interests of the State was not necessarily a safeguard for the interests of a community within the State.

There were differing views on the need for some safeguard for the territorial integrity of States. Several participants attached importance to such reassurance for States, especially as in other similar contexts there was often such a safeguard to balance provisions tending towards the attainment of independence or accordingly, any threat to a State's territorial integrity, and that therefore, a safeguard on this point was inappropriate. Others saw emphasis on the protection of territorial integrity as a way of frustrating the right to self-determination through independence.

There was some reluctance to accept any prohibition on communities resorting to force in order to achieve their ends so long as States were still able to use force against communities, even in merely 'law and order' circumstances. Also, force by communities might be justified (e.g. by oppression by State authorities).

Several participants noted that democracy and the proper observance of human rights offered necessary safeguards (or perhaps pre-conditions) for the effective exercise of the right of selfdetermination.

Avoidance of foreign interference was suggested as a possible safeguard.

Some participants thought it best to avoid spelling out possible safeguards in detail: details would be best left to be worked out by the parties concerned, in the light of the 'genius of the people'.

\section{Automatic, initial level of autonomy; Optional, subsequent levels of autonomy}

The automatic initial level of autonomy was conceived as comprising the basic rights needed to safeguard and enhance a community's existence, and protect its separate identity within the fabric of the State. The optional subsequent levels of autonomy allowed for progressive additions to the degree to which the community conducted its own affairs.

Autonomy - like sovereignty and independence - was widely acknowledged not to be an 'all or nothing' concept, but rather one allowing for a gradual evolution and variable structures. The flexibility of the Liechtenstein initiative in this respect was widely welcomed.

Autonomy was thought to be a valuable concept, offering a socio-political structure which could help in the search for higher levels of freedom for individuals. But some noted that autonomy could also be divisive, as compared with the development of multicultural States: all groups within such States were in many respects interdependent.

Many participants noted that emphases on autonomy helpfully avoided, or at least severely limited, problems which could arise with proposals emphasising the attainment of independence. Many communities would not want independence, but would be satisfied with something considerably less, so long as it allowed sufficient expression for a community's own identity. Autonomy could therefore be an 
adequate expression of self-determination, without necessarily undermining other forms of selfdetermination.

The relationship of autonomy and federalism was noted by some participants.

A number of participants thought that a linear approach to various stages of autonomy (with each stage, with the addition of extra elements, leading on to the next stage), could be too rigid: a more flexible, a la carte, approach might be better, allowing communities to suit their progress more exactly to their needs: the reality was likely to be a process of constant dialogue, leading to all kinds of development in many different directions.

\section{Other pertinent issues}

Many participants referred to the need for mechanisms to support any new arrangements which might be introduced, in order to secure their effectiveness in practice.

It was noted, and widely welcomed, that the underlying purpose of the Liechtenstein initiative appeared to be to find ways of avoiding the conflicts which often arose through communities not being allowed adequate means of self-expression. In that context several participants thought that an 'early warning system' was needed, to identify situations in which such conflicts might erupt.

It was noted that civil wars within States were often more a matter of differences between political leaders than of conflicting aspirations of differing groups within States. The real causes of internal conflicts needed study.

Several participants noted that at present there were no adequate mechanisms to help with seifdetermination issues. Many saw value in establishing new fora, or a new procedural framework, for such issues, including dispute settlement problems which could arise in that context. Mechanisms for coordination were thought useful by some participants.

The establishment of some kind of international advisory centre was suggested, to which Governments and communities could turn for advice on possible options for governmental structures appropriate for the particular self-determination problems they faced.

Some participants warned against the establishment of new inter governmental institutions, without a very clear idea of what functions they would fulfil: there were already some existing institutions with functions in at least part of this field. Optional mechanisms or processes might offer a more useful way forward; as might the encouragement of private law bodies which could be active in this field.

New York

20 September 1993

Source: Herb Feith, 1993, The East Timor Issue Since the Capture of Xanana Gusmao, East Timor Talks Campaign, Melbourne. 


\section{Bibliography}

Secondary Sources

Aarons, Mark and Domm, Robert

1992 East Timor: A Western Made Tragedy, The Left Book Club, Sydney, NSW.

Akehurst, Michael

1984 A Modern Introduction to International Law, Allen \& Unwin, London.

Alley, Roderic

1994 The United Nations and Asia-Pacific: An Overview, The Pacific Review, Vol. 7 No. 3, p.245 - 260 .

Anti-Slavery Society

1990 "Ten Days in East Timor" Journal of Contemporary Asia, 20:1, p.141.

Asia Yearbook

1994 "Indonesia" Far Eastern Economic Review:Asia Yearbook 1994, p.134-140

Asiaweek

1994 "Facing Facts: The World Should Accept That East Timor Is a Part of Indonesia", Asiaweek, March 23, p.27.

Awanohara, Susumu, Vatikiosis, Michael, \& Islam, Shada

1993 "Vienna Showdown”, Far Eastern Economic Review, June 17, p. 16-20.

Azram, Suhaini

1993 "In But Out: Indonesia Continues to Integrate East Timor" Far Eastern Economic Review, February 25, p.22.

Barclay, Glen St. J.

1993 "Problems of Australian Foreign Policy, July - December 1992" Australian Journal of Politics and History, 39: 2, 140-159.

Blunden, Verge

1994 “Treaty With Indonesia Challenged", Sydeny Morning Herald, August 10, p.8.

Bot, B.R.

1968 Non-Recognition and Treaty Relations, Oceana Publications Inc., Dobbs Ferry, New York.

Breen, Gavan

1993 Let Them Be: West Papua Revisited, Australia West Papua Association, Melbourne.

Brownlie, Ian

1967 Basic Documents in International Law, Clarendon Press, Oxford.

Buchheit, Lee C.

1978 Secession: the Legitimacy of Self-determination, Yale University Press, New Haven.

Budiardjo, Carmel

1994a "For Fear of a Showdown" New Internationalist, No. 253, March, p.13-15.

1994b “A Colonised Nation” New Internationalist, March, p.17-19.

B.U.K.O.

1994 "Germany" in Martin Broek (ed), Stop Arming Indonesia: A European Perspective on Arms Trade to a Military Regime, European Campaign Against Arms Trade, Amsterdam. 
Burns, Brendon

1994a "Bolger Objects to Timor Criticism" The Press, May 18, p.3.

1994b "Bolger Takes Indonesian Line on East Timor" The Press, May 17, p.1.

1994c "Bolger Ignores Human Rights in Speeches" The Press, May 17, p.3.

Caldwell, Malcom \& Utrecht, Ernst

1979 Indonesia: An Alternative History, Alternative Publishing Cooperative Ltd, Sydney.

Campaign Against the Arms Trade

1994 "United Kingdom" in Martin Broek (ed), Stop Arming Indonesia: A European

Perspective on Arms Trade to a Military Regime, European Campaign Against Arms Trade, Amsterdam.

Chabal, Patrick

1983 Amilcar Cabral: Revolutionary Leadership and People's War, Cambridge University Press, Cambridge.

Ching, Frank

1993 "Asian View of Human Rights is Beginning to Take Shape", Far Eastern Economic Review, April 17, 1993, p.27.

Clark, Roger S.

1992 "Timor Gap: The Leagality of the "Treaty on the Zone of Cooperation in an Area Between the Indonesian Province of East Timor and Northern Australia"', Pace Yearbook of International Law, 4:69, p.69-95.

Cohen, Margot

1993 "Velvet Fist: Indonesia Opts For Subtlety in its Efforts to Subdue East Timor" Far Eastern Economic Review, April 29, p.24-26.

Crawford, James

1979 The Creation of States in International Law, Clarendon Press, Oxford.

Crichton, Sarah

1994 "Push for East Timor Aid Likely - MP" The Dominion, November 2, p.15.

Crouch, Harold

1990 "Indonesia and the Security of Australia and Papua New Guinea" in Desmond Ball \& Cathy Downes (eds), Security and Defence: Pacific and Global Perspectives, [publisher], Sydney, N.S.W.

1978 The Army and Politics in Indonesia, Cornell University Press, Ithaca, New York.

Dannilenko, Gennady M.

1991 "The Changing Structure of the International Community: Constitutional Implications", Harvard International Law Journal, 32:2, p.353-361.

Davidson, Scott

1993 Human Rights, Open University Press, Buckingham.

Dunn, James

1983 Timor: A People Betrayed, The Jacaranda Press, Queensland.

Dupuy, Rene-Jean

1974 The Law of the Sea, Current Problems, Oceana Publications Inc., Dobbs Ferry, New York.

Eide, Asbjorn

1985 "Indigenous Populations and Human Rights: The United Nations Efforts at Midway" in Brosted, Jens et al, Native Power: The Quest for Autonomy and Nationhood of Indigenous Peoples, Universitetsflorlaget As, Oslo. 
van Essen, Niek

1994 "Netherlands" in Martin Broek (ed), Stop Arming Indonesia: A European Perspective on Arms Trade to a Military Regime, European Campaign Against Arms Trade, Amsterdam.

Evans, Gareth

1993 Cooperating for Peace: The Global Agenda for the 1990s and Beyond, Allen \& Unwin, St Leonards, NSW.

Falk, Jim \& Camilleri, Joseph

1992 The End of Sovereignty? The Politics of a Shrinking and Fragmenting World, Edward Elgar, Aldershot, England.

Feith, Herbert

1993 The East Timor Issue Since the Capture of Xanana Gusmao, The East Timor Talks Campaign, Melbourne.

1987 "Political Control, Class Formation and Legitimacy in Suharto's Indonesia" in Doran, Christine (ed), Indonesian Politics: A Reader, Centre for South East Asain Politics, J ames Cook University of North Queensland, Australia.

1963 "Dynamics of Guided Democracy" in Ruth T McVey (ed), Indonesia, Hraf Press, Yale University, New Haven.

Fonteyne, Jean-Pierre L.

1991 "The Portuguese Timor Gap Legislation Before the International Court of Justice: A Brief Appraisal of Australia's Position", Australian Journal of Internaitonal Affairs 45:2, p.170-181.

Franke, Richard W.

1983 "East Timor: The Responsibility of the United States" Bulletin of Concerned Asian Scholars, Vol. 15, No. 2, p.42-58.

Fuhrman, John

1993 "East Timor: An Intractable Problem", New Zealand International Review, Vol.18, No.1., p. 26-29.

Gault-Williams, Malcolm

1990 "Funu - Liberation War - Continues in East Timor", Bulletin of Concerned Asian Scholars, Vol. 22, No. 3, p.21 - 31.

Gietzelt, Dale

1989 “The Indonesianisation of West Papua", Oceania, Vol.59, No.3, p.201-245.

Goff, Phil

1994 "Benevolent Rule the Answer" The Evening Post, November 15, p.5.

1978 "The Australian and New Zealand Response to the East Timor Controversy", paper presented to the Political Science Department, University of Auckland, unpublished.

Gottleib, Gidon

1993 Nationa Against State: A New Approach to Ethnic Conflicts and the Decline of Sovereignty, Council of Foreign Relations Press, New York.

Gulcher, Ernst

1994 "Belgium" in Martin Broek (ed), Stop Arming Indonesia: A European Perspective on Arms Trade to a Military Regime, European Campaign Against Arms Trade, Amsterdam.

Gunn, Geoffrey C.

1994 A Critical View of Western Journalism and Scholarship on East Timor, Journal of Contemporary Asia Publishers, Australia. 
Halperin, Morton H., Scheffer, David J. \& Small, Patricia L.

1992 Self-determination in the New World Order, Carnegie Endowment for International Peace, Washington D.C.

van den Ham, Allert P.

1993 "Development Co-operation and Human Rights", Asian Survey, Vol. 33, No. 5, p. $531-539$.

Hamilton, John

1995 "Suharto: The Puppet Master", Herald Sun, July 1, p. 23 - 25.

Harris, Stuart \& Bridges, Brian

1983 European Interests in ASEAN, Routledge and Kegan Paul, London.

Hastings, Peter

1984 "Two Weeks in Politics" Far Eastern Economic Review, July 12, p.13.

Hegarty, David

1991 "Australia, Indonesia and Stability in the South Pacific", in Desmond Ball and Helen Wison (eds), Strange Neighbours: The Australia - Indonesia Relationship, Allen and Unwin, Sydney.

Heraclides, Alexis

1991 The Self-determination of Minorities in International Politics, Frank Cass, London.

Hinsley, F.H.

1986 Sovereignty (2nd ed), Cambridge University Press, Cambridge.

Hoadley, Stephen J.

1977 "Indonesia's Annexation of East Timor: Political, Administrative and Development Initiatives”, Southeast Asian Affairs, Institute of Southeast Asian Studies.

1976 "East Timor: Civil War - Causes and Consequences", Southeast Asian Affairs, Institute of Southeast Asian Studies.

1975a Portuguese Timor's Three Options, New Zealand Institute of International Affairs, Auckland.

1975b The Future of Portuguese Timor, Occasional Paper No.27, Institute of Southeast Asian Studies, Singapore.

Holsti, K. J.

1983 International Politics: A Framework for Analysis 4th ed., Prentice-Hall, New Jersey.

Howard, Tim

1994 East Timor: New Zealand's Waterloo? Background Paper 11/19, Foundation for Peace Studies, Aotearoa/New Zealand.

Jackson, Robert H. \& James, Alan

1993 "The Character of Independent Statehood" in Jackson, Robert H. \& James Alan (eds) States in a Changing World: A Contemporary Analysis, Clarendon Press, Oxford.

Jackson, Robert H.

1990 Quasi-states: Sovereignty, International Relations and the Third World, Cambridge University Press, Cambridge.

Janis, Mark W.

1991 "International Law?", Harvard International Law Journal, Vol. 32 No. 2, p.363 - 372

Jenkins, David

1984 Suharto and his Generals: Indonesian Military Politics 1975 -1983, Cornell Modern Indonesia Project, Cornell University, Ithaca, New York. 
1980 "Death of a Dream of Freedom" Far Eastern Economic Review, May 23, p.30-34.

Johnston, Douglas

1992 "Theory, Consent, and the Law of Treaties: A Cross Disciplinary Perspective" Australian Yearbook of Internationa Law, Vol 12, p.109-124.

Joliffe, Jill

1994 "Jakarta Launches New Offensive", Sydney Morning Herald, August 26, p.10.

1978 East Timor: Nationalism and Colonialism, University of Queensland Press, St.

Lucia.

Kelly, Andrew

1995 “Australia Wins World Court Ruling in Timor Oil Row”, Reuter News Service, June 30 .

1995 "Netherlands: Portugal Says Timor Oil 'Tainted with Blood"' Reuter News Service, January 30.

Kerr, Pauline

1994 "The Security Dialogue in the Asia-Pacific" The Pacific Review, 7:4, p.397-409.

Kevin, Tony

1991 "Major Power Influences on the Southeast Asian Region: An Australian View" in Desmond Ball and Helen Wilson (eds), Strange Neighbours: The Australian - Indonesian Relationship, Allen and Unwin, Sydney.

Kristiadi

1986 "The Decolonisation of East Timor: A Historical Review", The Indonesian Quarterly, Vol.14, No. 4, p. 546-577.

Lagerberg, Kees

1979 West Irian and Jakarta Imperialism, C. Hurst \& Co., London.

Lane, Max

1984 "Culture of Contempt" New Internationalist, No. 253, March, p.8-9.

Land, John

1994 "East Timor Will Be Free”, The Green Left Weekly, June 15, p.16-17.

Lehmann, Jean-Pierre

1994 "Reorganizing Western Cooperation: A Prescription for a Collective Pax Americana", The Pacific Review, Vol.7, No.2, p.141-152.

Leifer, Michael

1983 Indonesia's Foreign Policy, George Allen and Unwin, London.

1976 "Indonesia and the Incorporation of East Timor", The World Today, 32:9. p.347-354.

Levi, Werner

1976 Law and Politics in the International Society, Sage Publications, Beverly Hills.

Luard, Evan \& Heater, Derek

1994 The United Nations: How it Works and What it Does (2nd ed), MacMillan, Basingstoke.

Lumb, R.D.

1981 "The Delimitation of Maritime Boundaries in the Timor Sea", Australian Yearbook of International Law, Vol 7, p.72-86.

MacIntyre, Andrew

1993 "Indonesia in 1992: Coming to Terms with the Outside World", Asian Survey, Volume 33, No. 2, p. 204 - 210. 
Mackie, J.A.C.

1986 "Does Indonesia Have Expansionist Designs on Papua New Guinea?", in R.J. May (ed), Between Two Nations: The Indonesia Papua Border and West Papuan Nationalism, Robert Brown and Associates (Aust) Pty. Ltd., Bathurst, N.S.W.

MacLennan, Catrionna

1995a "Two Sides to East Timor Story, says McKinnon" The Dominion, March 22, p.2.

1995b "Report on East Timor Deaths Heightens Concern - PM" The Dominion, March 3, p.3.

1994a "NZ's Diplomacy Over East Timor Defended" The Dominion, November 17, p.2.

1994b "Defiance Behind the Propaganda" The Dominion, November 4, pg11.

Magalhaes, A. Barbedo de

1992 East Timor: Indonesian Occupation and Genocide, Presidents Office, Oporto

University.

Malik, Adam

1980 In the Service of the Republic, P T Gunung Agung, Jakarta.

Martin, William \& Pickersgill, Dianne

1991 "Recent Developments: The Timor Gap Treaty", Harvard International Law Journal, Vol 32, p.577-581.

McCormick, James M.

1992 American Foreign Policy and Process, F.E. Peacock Publishers, Inc., Itasca, Illinois.

McCraw, David J.

1994 "New Zealand's Foreign Policy Under National and Labour Governments: Variations on the Small State Theme?", Pacific Affairs, Vol. 67, No. 1, p. 7-25.

McCulloch, Jock

1983 In the Twilight of Revolution: The Political Theory of Amilcar Cabral, Routledge and Keegan Paul, London.

McGregor, Charles

1993 "Southeast Asia's New Security Challenges", The Pacific Review, Vol.6, No.3, p.267-276

McGuire, G. \& Hering, B.

1987 "The Indonesian Army: Harbingers of Progress or Reactionary Predators?", in Doran, Christine (ed), Indonesian Politics: A Reader, Centre for South East Asian Politics, James Cook University of North Queensland, Australia.

McMillan, Stuart

1987 Neither Confirm Nor Deny: The Nuclear Ships Dispute Betwen New Zealand and the United States, Allen and Unwin/ Port Nicholson Press, Wellington.

McNair, Lord

1958 "Treaties and Sovereignty", Appendix A of The Law of Treaties, Clarendon Press, Oxford.

McPhedran, Ian

1993 "Self-determination Basis of Court Move", The Canberra Times, June 26, p.15.

Merriam, C.E. Jr.

1968 History of the Theory of Sovereignty Since Rousseau, AMS Press, New York.

Middleton, Karen

1995, "Left Slams Policy on East Timor", The Age, July 3, p.4. 
Mody, Nawaz B.

1987 Indonesia Under Suharto, Oriental University Press, London.

Morphet, Sally

1993 "The Non-Aligned Movement in the New World Order: The Jakarta Summit, September 1992", International Relations, Vol. 10, No. 4, p.361 - 378.

Murdoch, Lindsay

1994a "Time to Look Beyond Suharto", The Sydney Morning Herald, June 27, p.13.

1994b “Timor Not Tamed, Indonesians Admit", The Age, April 18, p.11.

Nichterlein, Sue

1982 "Australia: Courtier or Courtesan? The Timor Issue Revisited", Australian Outlook, $36: 1$, p.46-49.

Ofuatey-Kodjoe, W.

1977 The Principle of Self-Determination in international Law, Nellen Publishing Co. Inc, New York.

Oliveres, Arcadi

1994 "Spain: Interests in the Region" in in Martin Broek (ed), Stop Arming Indonesia: A European Perspective on Arms Trade to a Military Regime, European Campaign Against Arms Trade, Amsterdam.

Otten, Mariel,

1986 Transmigrasi: Indonesian Resettlement Policy; 1965 - 1985; Myths and Realities, IWIGA Document \#57, Copenhagen.

Paust, Jordan J.

1980 "Self-determination: A Definitional Focus", in Alexander,Y. and Friedlander, R.A., Self - determination: National, Regional and Global Dimensions, Westview Press, Boulder, Colorado. Pgs 3 -18.

Pereira, Agio

1994 "Against Selective Amnesia: The Tragedy of East Timor", The Evatt Papers, Vol.2, No.1, p. 103-117.

Pilger, John

1994 "East Timor: A Land of Crosses", New Internationalist, No. 253, March p.4-7.

Pringle, Robert

1980 Indonesia and the Philippines: American Interests in Island Southeast Asia, Columbia University Press, New York.

Ramos-Horta, Jose

1987 Funu: The Unfinished Saga of East Timor, The Red Sea Press, Inc., Trenton, New Jersey.

Robison, Richard

1993 "Indonesia: Tensions in State and Regime", in Kevin Hewison, Richard Robison \& Garry Rodan (eds), Southeast Asia in the 1990s: Authoritarianism, Democracy and Capitalism, Allen \& Unwin, St Leonards, NSW.

1992 "Indonesia: An Autonomous Domain of Social Power?" The Pacific Review , 5:4, p.338-349.

Retboll, Torbin

1987 "The East Timor Conflict and Western Response" Bulletin of Concerned Asian Scholars, Vol. 19, No. 1, p. 24-40.

1983 "East Timor and Indonesia" Bulletin of Concerned Asian Scholars, 15:2, p.59-61. 
Reuter News Service

1995 “Australia Welcomes World Court's Timor Decision”, Reuter News Service June 30 .

Rigg, Johnathan

1991 Southeast Asia: A Region in Transition, Unwin Hyman Ltd., London.

Robie, David

1992 “"Betrayal' by the South Pacific”, Pacific Islands Monthly, January, p.18 - 19.

1989 Blood on Their Banner: Nationalist Struggles in the South Pacific, Pluto Press, Leichhardt, N.S.W.

Robison, Richard

1993 "Indonesia: Tensions in State and Regime" in Kevin Hewison, Richard Robison \& Garry Rodan (eds), Southeast Asia in the 1990s: Authoritarianism, Democracy and Capitalism, Allen and Unwin, Sydney

1992 "Indonesia: An Autonomous Social Power?" The Pacific Review, Vol. 5. No. 4, pgs $338-349$.

Roff, Sue Rabbitt

1992 Timor's Anschluss: Indonesian and Australian Policy in East Timor 1974-1976, The Edwin Mellen Press, New York.

Ronen, Dov

1979 The Quest for Self-determination, Yale University Press, New Haven.

Rose, Mavis

1982 Indonesia Free: A Political Biography of Mohammad Hatta, Cornell Modern Indonesia Project Monograph Series \#67, Ithaca, New York.

Schouten, Hank

1994a "Timor Policy Based on Colonial View" The Evening Post, November 3, p.1.

1994b "Bleak View on a Brutal Invasion" The Evening Post, November 3, p.5.

Sheridan, Greg

1994 "Silencing the Messenger", The Weekend Australian, June 25-26, p.25.

Sidell, Scott

1981 "The United States and Genocide in East Timor", Journal of Contemporary Asia, $11: 1$, p.44-60.

Siracusa, Joseph M.

1994 "Problems in Australian Foreign Policy, January - July 1994", The Australian Journal of Politics and History, Vol.40, No.3, p.295-303.

Soesastro, M. Hadi

1989 "East Timor: Questions of Economic Viability" in Hal Hill (ed), Unity and Diversity: Regional Development in Indonesia Since 1970, Oxford University Press, Singapore, p.207 -229.

Stepan, Sasha

1992 "Portugal's Action in the Internaitonal Court of Justice Against Australia Concerning the Timor Gap Treaty", Melbourne University Law Review, Vol 18, p.918-927.

1990 Credibility Gap: Australia and the Timor Gap Treaty, Development Dossier \#28, Australian Council for Overseas Aid, Canberra. 
Suter, Keith

1993 "Timor Gap Treaty: The Continuing Controversy", Marine Policy, July, p.294-302.

1982 East Timor and West Irian, Minority Rights Group Report \# 42, (revised ed)

1979 West Irian, East Timor and Indonesia, Minority Rights Group Report \# 42, London

1978 "The Conquest of East Timor", Contemporary Review, 232:1346, March, p.134-

141.

Swedish Peace and Arbitration Society

1994 "Sweden" in Martin Broek (ed), Stop Arming Indonesia: A European Perspective on Arms Trade to a Military Regime, European Campaign Against Arms Trade, Amsterdam.

Sztucki, Jerzy

1974 Jus Cogens and the Vienna Convention on the Law of Treaties: A Critical Appraisal, Springer Verlag, Wein, New York.

Taber, Robert

1969 The War of the Flea: Guerilla Warfare in Theory and Practice, Paladin, St. Albans.

Taylor, John G.

1994 “A Brief History of East Timor" New Internationalist, March, p.10-12.

1991 Indonesia's Forgotten War: The Hidden History of East Timor, Zed Books, London.

Taylor, Peter J.

1989 Political Geography: World Economy, Nation State and Locality, Longman, New

York.

Tremewan, Christopher

1993 "Human Rights in Asia", The Pacific Review, Vol.6, No.1, p.17-29.

Trotter, Chris

1994 “Art of Diplomacy" [memeo].

Vatikiotis, Michael R.J.

1993 Indonesian Politics Under Suharto: Order, Development and Pressure for Change, Routledge, London.

Wagstaff, Jeremy

1995 "Indonesia: East Timor Said Still Far From Peaceful" Reuter News Service, February 20.

Walker, R.B.J.

1984 "World Politics and Western Reason: Universalism, Pluralism, Hegemony", in R.B.J. Walker (ed) Culture, Ideology and World Order, Westview Press Inc, Boulder, Colorado, p.182 - 216.

Walters, Patrick

1994 “Clinton Steps Up Policy on East Timor”, The Australian, July 19, p.1.

Wanandi, Jusuf

1991 "Developments and Challenges in the South Pacific" in Desmond Ball and Helen Wilson (eds), Strange Neighbours: The Australian - Indonesian Relationship, Allen and Unwin, Sydney.

Wertheim, W.F.

1987 "Fissures in the Girdle of Emeralds" in Doran, Christine (ed), Indonesian Politics: A Reader, Centre for South East Asian Politics, James Cook University of North Queensland, Australia. 
Weatherbee, Donald E.

1966 "Portuguese Timor: An Indonesian Dilemma", Asian Survey, Vol.6, No.12, p.683-

695.

Williams, Ian

1992a “The East Timor Dilemma”, Pacific Islands Monthly, October, p. 13.

1992b “East Timor Back on the Floor”, Pacific Islands Monthly, January, p.15.

Wilson, Heather A.

1988 International Law and the Use of Force by National Liberation Movements, Clarendon Press, Oxford.

Young, Thomas-Durrell

1994 "Prospects for Future Australian-United States Defence Cooperation", The Pacific Review, Vol.7, No.2, p.195-204.

\section{Video recordings}

Gil Sarine Films

1993 Death of a Nation - The East Timor Conspiracy, Australia.

1987 One People, One Soul, Australia.

Necessary Illusions

1992 Manufacturing Consent: Noam Chomsky and the Media, Canada

Yorkshire Television

1992 In Cold Blood - The East Timor Massacre, United Kingdom.

\section{Interviews and unpublished sources}

Capie, David, "Regional Security in the Asia - Pacific: A Critical Theoretical Perspective" paper presented at the New World Order Conference, Centre for Strategic Studies, Victoria University of Wellington, December 9, 1994; unpublished.

Clark, Helen, Speech on human rights violations in East Timor, given in Parliament, March 7, 1995

Dunn, James, former Australian consul to Indonesia and political columnist; public talk, Turnbull House, Wellington, June 29, 1994.

East, Maurice, "Foreign Policy - Making in the Post COld War Era: The Case of New Zealand"paper presented at the New World Order Conference, Centre for Strategic Studies, Victoria University of Wellington, December 9, 1994; unpublished.

East, Maurice, "The Foreign Policy of Small States", talk given at the Institute for Strategic Studies, Victoria University of Wellington, October 4, 1994.

Evans, Gareth, “Australian Foreign Minister on International Court Ruling on Timor Gap Treaty”, Radio Australia, 1100 GMT, July 4, 1995.

Goff, Phil \& Cooper, Warren, question in Parliament asked by Phil Goff of Warren Cooper, Minister of Defence, regarding New Zealand defence forces involvement in a military exercise with Indonesia, March 7, 1995.

Goff, Phil, MP for Roskill; interview with the author, June 28, 1994, Bowen House, Wellington.

Graham, Doug, Minister for Treaty Negotiations; interview with Mike Hosking, Morning Report, National Radio 2YA, 7:09 AM, May 4, 1995.

Guterres, Abel, representative of the National Council of Maubere Resistance; public talk, September 13, 1994, Turnbull House, Wellington. 
Maitra, Priyatosh, "The End of the Cold War, Internationalisation of the Production Phase of Capitalism, and the Negation of Nation States", paper presented at the New World Order Conference, Centre for Strategic Studies, Victoria University of Wellington, December 9, 1994; unpublished.

Pettman, Jan Jindy, "Worlding Women", paper presented at the New World Order Conference, Centre for Strategic Studies, Victoria University of Wellington, December 9, 1994; unpublished.

Pearson, Leigh, item on New Zealand conducting military exercises with Indonesia, One Network Newa, March 7, 1995.

Regan, Patrick "Thrid Party Intervention in Intra - State Conflicts: Mapping Strategies for Stopping the Violence", paper presented at the New World Order Conference, Centre for Strategic Studies, Victoria University of Wellington, December 9, 1994; unpublished.

Vasquez, John A., "Peace and the New World Order", keynote address to the New World Order Conference, Centre for Strategic Studies, Victoria University of Wellington, December 9, 1994; unpublished.

\section{NGO and government publications and documents}

Amnesty International

1994 Power and Impunity: Human Rights Under the New World Order, Amnesty International Publications, London.

1993 Amnesty International Report 1993, Amnesty International Publications, London.

1993 East Timor: State of Fear, Statement before the United Nations Committee on Decolonisation, July 13; AI Index ASA 21/15/93, International Secretariat, London.

Australian Department of Foreign Affairs and Trade

1990 Annual Report 1989-90, Australian Government Publishing Service, Canberra.

1989 Annual Report 1988-89, Australian Government Publishing Service, Canberra.

1983 Annual Report 1982 , Australian Government Publishing Service, Canberra.

1982 Annual Report 1981, Australian Government Publishing Service, Canberra.

1979 Annual Report 1978, Australian Government Publishing Service, Canberra.

1978 Annual Report 1977, Australian Government Publishing Service, Canberra.

Catholic Institute for International Relations

1992, East Timor: An International Responsibility, Russell Press Ltd., Nottingham.

Department of Foreign Affairs, Republic of Indonesia

1984 East Timor After Integration, Department of Foreign Affairs, Republic of Indonesia, 2nd edition.

1977 Decolonization in East Timor, Department of Foreign Affairs, Republic of Indonesia.

Department of Public Information

1979 Everyone's United Nations, 9th Edition, United Nations, New York

Evans, Gareth

1991a "Australia-Indonesia Ties:Timor Gap Zone of Cooperation", [Australian Department of Foreign Affairs] Monthly Record, February, p.45-46. 
1991b "Global and Regional Security After the Gulf", [Australian Department of Foreign Affairs] Monthly Record, February, p.39-44.

"Forum For Realising the True Sovereignty" Conference, Jakarta, August 22, 1991, documents reprinted in Indonesia, No. 53, April, 1992, p.137-165.

Information and Culture Section,

1992 "The Tenth Non-Aligned Movement Summit, Jakarta 1-6 September 1992" Indonesia Bulletin, Indonesian Embassy, Wellington.

International Court of Justice

1993 International Court of Justice Yearbook 1992-1993, The Hague.

Matebian News

1994 “United Nations Move Further on East Timor”, Matebian News, Vol.1, No.10, February, p.2

1993 "Timor Gap Treaty: Timorese Refugees Challenge the Commonwealth of Australia", Matebian News, Vol.1, No. 3, June, p.1-3.

New Zealand Ministry of Foreign Affairs and Trade

1992 ASEAN and New Zealand, Ministry of Foreign Affairs Information Bulletin No.40, September.

1986 Perspectives on New Zealand's Foreign Policy, Ministry of Foreign Affairs Information Bulletin No. 19, November.

1995 Documents relating to East Timor, 1974 - 1985, released under the Official Information Act at the request of Phil Goff, MP for Roskill, unpublished.

United Nations

Charter of the United Nations, brought into force on June 26, 1945.

The Convention on the Territorial Sea and Contiguous Zone, United Nations Doc A/Conf. 13/L. 52

The Convention on the Continental Shelf, United Nations Doc A/Conf. 13/L. 55.

The Declaration on the Granting of Independence to Colonial Countries and Peoples, General Assembly Resolution 1541 (XV).

The Declaration on Principles of International Law Concerning Friendly Relations and Co-operation Among States in Accordance with the Charter of the United Nations, General Assembly Resolution 2625 (XXV).

The International Covenant on Economic, Social and Cultural Rights, General Assembly Resolution 2200A (XXI)

The International Covenant on Civil and Political Rights, General Assembly Resolution 2200A (XXI)

The Statute of the International Court of Justice. 